\title{
O CESTO KAIPÓ DOS KRAHÓ: UMA ABORDAGEM VISUAL
}

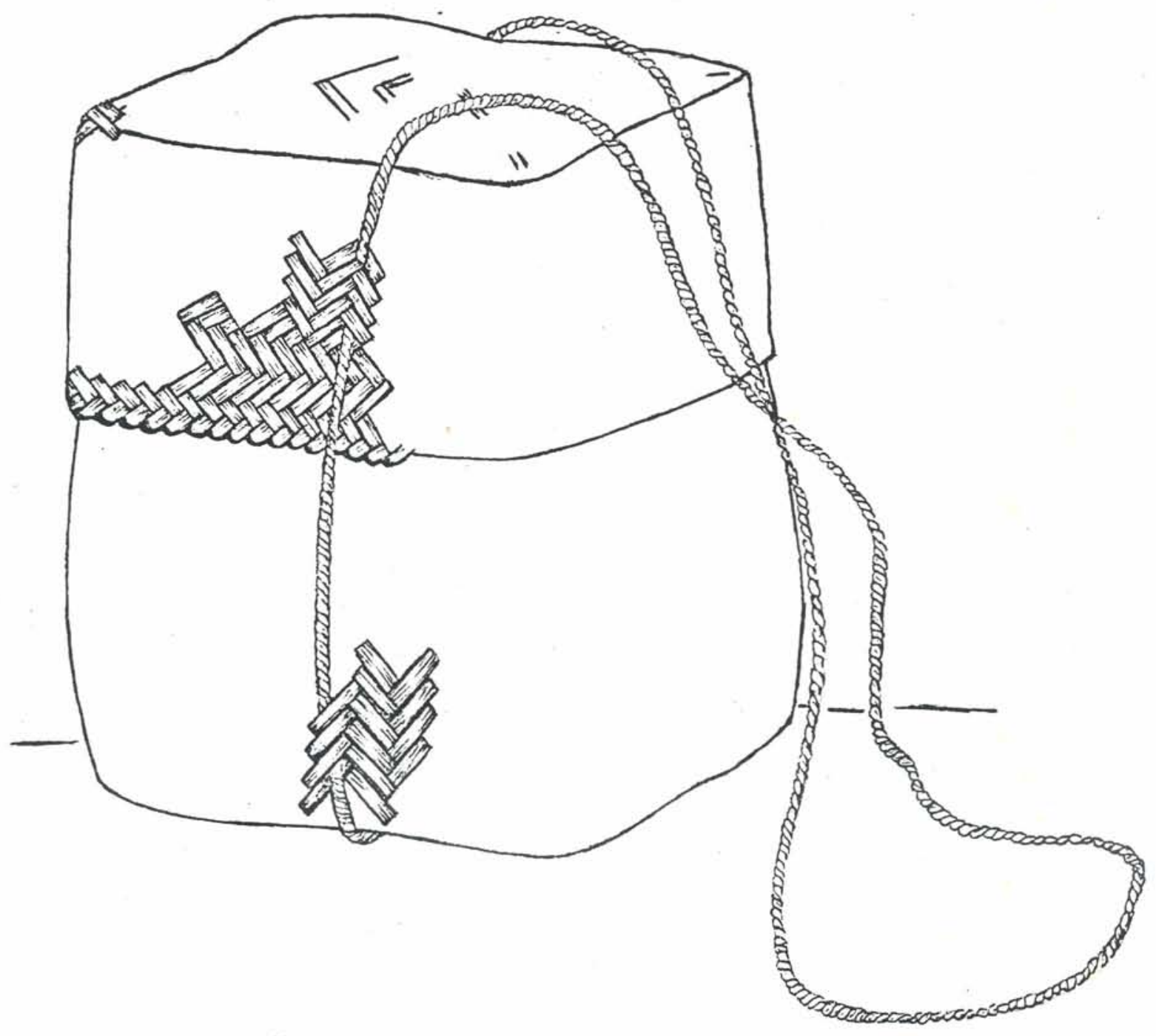

Dissertação apresentada ao Departamento de Antropologia da Faculdade de Filosofia, Letras e Ciências Humanas da Universidade de São Paulo para obtenção do Grau de Mestre na Área de Antropologia Social.

Orientadora: Profa. Dra. Thekla O. Hartmann

\section{São Paulo}


Dedico esse pequeno estudo aos Krahó e à minha filhinha Líris. 


\section{AGRADECIMENTOS}

Minha gratidão à minha orientadora Dra. Thekla $\mathbf{O}$. Hartmann que com paciência apoiou-me e orientou-me com precisão de mestra.

Agradeço de modo especial à Profa. Dra. Lux B. Vidal pela credibilidade, incentivo e leituras a mim oferecidas.

Agradeço ao Centro de Trabalho Indiginista nas pessoas de Gilberto Azanha e Maria Elisa Ladeira por orientar-me no contato com os Krahó.

Agradeço à Coordenadoria de Aperfeiçoamento do Pessoal do Ensino Superior pelo apoio financeiro concedido sob a forma de bolsa de apoio à pesquisa.

Agradeço à Fundação Nacional do Índio pela cooperação prestada por seus funcionários na área indigena dos Krahó.

Agradeço à Profa. Dra. Mizue Imoto Egami da Escola Paulista de Medicina por ajudar-me a superar minhas deficiências quanto à apresentação técnica desse estudo.

Agradeço a Licurgo Lima de Carvalho ao prestimoso trabalho de digitação, que integrando textos e imagens viabilizou a apresentação deste estudo. 
Agradeço à comunidade Krahó pela experiência renovadora; sou grata especialmente a Edvaldo-Pentí, Sr. Messias, a Tüi e a Txuc-Txuc pela generosidade e ensinamentos.

Aos meus pais agradeço pelo apoio, compreensão e carinho. 


\section{ÍNDICE}

Introdução

I - Krou-Ro: A Matéria-Prima do Kaipó ................................. 12

II - Kaipó Era o Armarinho da Mulher...................................26

III - Análise Visual da Tecnologia do Kaipó...............................4 48

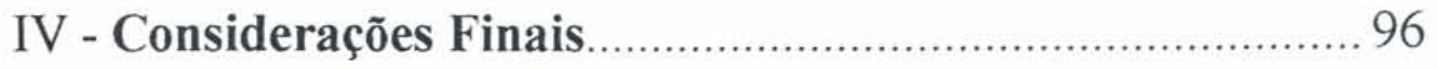

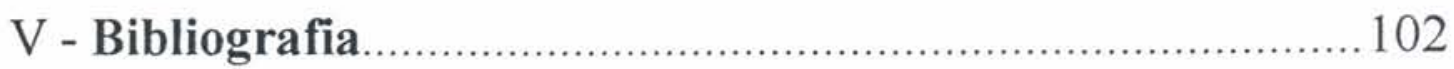

VI - RESUMO 


\section{INTRODUÇÃO}

"Nossas experiências e idéias tendem a ser comuns mas não profundas, ou profundas mas não comuns. Temos negligenciado o dom de compreender as coisas através dos nossos sentidos. O conceito está divorciado do que se percebe e o pensamento se move entre abstrações. Nossos olhos foram reduzidos a instrumentos para identificar e para medir; daí sofrermos de uma carência de idéias expremíveis em imagens e de uma capacidade de descobrir significado no que vemos. É natural que nos sintamos perdidos na presença de objetos com sentido apenas para uma visão integrada e procuremos refúgio num meio mais familiar: o das palavras".

ARNHEIM, Arte e Percepção Visual, (1954), 1980, p. XIII.

ARNHEIM (1980) exprime aqui com clareza o meu próprio entendimento, que me levou,desde o primeiro impulso em direção à antropologia, a buscar uma abordagem do meu tema de estudo, baseada não apenas no que se diz do artefato, mas principalmente o que o artefato é em si; interessava-me o que poderia aprender, conhecendo-o.

Nesse processo de aprendizado a aquisição dos conhecimentos e sua transmissão teve no desenho de observação um grande aliado, de onde vem o seu título: "O cesto Kaipó dos Krahó uma abordagem visual". 
O grupo indígenas Khahó habita a região dos cerrados próxima ao rio Tocantins, no Estado do Tocantins. A posse desse território de aproximadamente $3.200 \mathrm{~km} 2$ lhes foi assegurada pelo governo do antigo Estado de Goiás, em 1944. Quando os visitei em 1990 existiam ali nove aldeias, a saber: Pedra Branca, Manoel Alves, Cachoeira, Santa Cruz, Galheiro, Morro do Boi, Pedra Furada, Forro Velho e Rio Vermelho.

Desde a década de 40 os Krahó têm sido amplamente estudados através de abordagens de sua organização social e de suas categorias de pensamento tanto como etnia quanto como componente da família linguística Jê-Timbira.

A cultura material dos Krahó, embora tenha chamado a atenção de pesquisadores pela quantidade de artefatos trançados vide RIBEIRO (1987) e OLIVEIRA (1980) - carece de estudos específicos, permanecendo, em grande parte, como potencial de investigação sobre essa sociedade.

O presente estudo recorta da cultura material dos Krahó a categoria dos trançados. Especificamente opta por concentrar-se em um único tipo de cesto - o Kaipó - porque tem como fundamental a obtenção de dados etnográficos fornecidos pela análise minuciosa e sistemática desse artefato.

Nosso objetivo foi, em um primeiro momento, procurar a inclusão do Kaipó na socieade Krahó. De fato, ele condensa e expressa necessidades utilitárias, vínculos sociais e a ordenação do cosmos nessa etnia. 
O processo de investigação do cesto Kaipó fez com que aprimorássemos os meios de abordá-lo: desenvolvemos o desenho de observação e reconstruímos a técnica usada para a confecção de alguns componentes do cesto. Tais meios revelaram com eficiência o potencial do artefato enquanto fornecedor de dados etnográficos, de modo que se tornou nosso objetivo também mostrar a utilidade desses meios para os estudos de cultura material, principalmente para aqueles que investigam os artefatos componentes dos acervos dos museus etnográficos, onde é ao artefato em si que questionamos em nossa vontade de nos aproximarmos do outro ser humano.

A noção de sistema perpassa esse estudo em dois níveis: na busca de relaçães entre a produção material e demais aspectos da referida sociedade e no tratamento dado à produção material analisada.

Ao considerarmos as relaçães entre a sociedade Krahó e o cesto Kaipó dialogamos, dentro da antropologia, principalmente, com a metodologia de GEERTZ (1983) e de MUNN (1979).

Ao abordar a arte como um sistema GEERTZ (1983), se expressa nos seguintes termos:"O sentimento que uma pessoa tem pela vida apresenta-se em muitos outros lugares mais que na sua arte: aparece na sua religião, sua moralidade, ciência, comércio, tecnologia, política, divertimentos, leis, organizando sua existência prática cotidiana". "O falar sobre a arte que não é meramente técnico ou espiritualização da técnica é largamente direcionado para colocá-lo dentro do contexto dessas outras expressões de propósito humano e 
do modelo de experiência coletivamente mantido" (GEERTZ, 1983: 96).

Primeiramente caberia perguntar se os cestos Kaipó são expressões artísticas dos Krahó. Segundo BOAS (1947) o esmero técnico é condição necessária e suficiente para se caracterizar um artefato como expressão artística. Na coleção de Kaipó estudada, a maioria dos exemplares primam pelo domínio da tecnologia, de maneira que poderíamos falar dos Kaipó como arte Krahó; mas essa não foi nossa preocupação no presente estudo. Mesmo assim, preferindo trabalhar não a arte, mas os artefatos como sistema, procuramos, como nos fala GEERTZ (1983) "o modelo de experiência coletiva" dos Krahó.

De modo apropriado, MUNN (1979) ao trabalhar o contexto da construção, troca e circulação das canoas Gawa no arquipélogo Papua - Nova Guiné, expande a noção de construção do artefato, que passa a abranger além da remodelagem física do meio material, operações verbais e demais modos de conversão. Propõe para essa operação o termo "fabricação" e assim se refere ao alcance de sua proposta: "Essa concepção de fabricação fixa o cenário para um estudo dos processos de fabricação não simplesmente como, por exemplo, construção tecnológica, mas preferivelmente como desenvolvimento de processos simbólicos que transformam igualmente propriedades socialmente significantes ou capacidades operacionais dos objetos, e aspectos significantes de relações entre pessoas e objetos, entre o humano e o mundo material" (MUNN, 1979: 39). 
Em nosso estudo, é com o sentido proposto acima que tentamos reconstruir a fabricação do cesto Kaipó.

Principiamos nosso estudo analisando uma coleção representativa de cestos Kaipó. Trata-se de 51 exemplares pertencentes ao acervo do Museu Paulista, coletados entre as décadas de 40 a 60 por Vilma Chiara e Harald Schultz nas várias aldeias Krahó.

Sabemos que, como afirma BOHANNAN (1963), a cultura material é o único fenômeno cultural codificado na mente do artesão e na forma física do objeto. Exatamente essa característica dupla - idéias e materiais - procuramos investigar nos Kaipó.

Dentre as ciências, é na psicologia da percepção, especificamente na teoria da Gestalt, que nos apoiamos ao analisar cada exemplar, una vez que o nosso discurso tem como básico o ato de ver o artefato e a palavra Gestalt refere-se a um conjunto de princípios científicos extraídos principalmente de experimentos de percepção visual. Para os psicólogos gestaltistas percebemos as formas como totalidades.

Aplicando o princípio acima ao trabalho como "design" (em sua concepção atual: atividade da qual resultam desenhos bi e tridimensionais), SCOTT (1979) propõe que as formas sejam investigadas como totalidades resultantes da interação entre as necessidades humanas-funcionais e expressivas, uma idéia formal, a matéria-prima adequada e a manipulação técnica. 
Essa concepção da criação das formas foi importante em nosso estudo na medida em que ela precisa exatamente as articulações entre idéias e materiais e enfatiza a forma como resultante de um processo complexo, isto é, como totalidade.

Como meio de análise da forma kaipó utilizamos o desenho de observação e a confecção de determinadas partes do cesto.

O desenho de observação parece um meio obsoleto frente ao uso consagrado atualmente da fotografia em nossa disciplina. A fotografia, no entanto, como a caracterizou BARTHES (1964) "tem algo de tautológico: um cachimbo, nela, é sempre um cachimbo, intransigentemente" (BARTHES, 1964:15). Diriamos que a tautologia na fotografia é fruto de seu processo de confecção, onde o olhar primeiro investiga e seleciona a forma a ser duplicada, reproduzindo a imagem do que foi visto antes do "click". Esse processo é eficaz para a ilustração, mas para a aquisição de conhecimentos, o desenho de observação mostra-se um meio superior.

$\mathrm{Na}$ atividade do desenho de observação escolhemos um ponto de vista e passamos a observar e a reproduzir cada linha que compõe o objeto em relação com as demais no espaço. É um trabalho onde ambos, o sentido da visão e a mente, se ocupam ao mesmo tempo com o caminho das linhas que compõem o objeto. Quanto mais sincrônicos forem o olho e a mente, mais a mão obedece ao traçado. Ao término do processo, o nosso conhecimento do objeto foi aumentado porque passamos a ver proporções e detalhes antes não percebidos. 
Ressaltamos que nessa abordagem do objeto a visão e a mente operam juntas produzindo novos conhecimentos.

\section{Em Fenomelogia do Olhar, BOSSI (1989) discorre} sobre a produção do conhecimento e sua relação com o ato de ver na tradição ocidental. Destacamos suas palavras sobre Leonardo da Vinci e sobre Merleau-Ponty porque em ambos encontramos identidade de propósitos com o desenho de observação usado em nosso estudo: "Leonardo, pintor-cientista, dá ao olho o poder de captar a prima verità de todas as coisas". "O olho, janela da alma, é o principal órgão pelo qual o entendimento pode obter a mais completa e magnífica visão dos trabalhos infinitos da natureza". Visão e entendimento estão aqui em estreitíssima relação: o olho é a mediação que conduz a alma ao mundo e traz o mundo à alma. Mas não é só o olho que vê; o entendimento, valendo-se do olho, "obtém a mais completa e magnífica visão" (BOSSI, 1989: 75). E referindo-se à leitura que Merleau-Ponty faz da criação plástica: "É uma operação de resgate desse olhar sintético e primordial do ser humano; olhar que...sentindo conhece, conhecendo sente, formando exprime, exprimindo forma" (BOSSI, 1989: 81). "Desde o prólogo à Fenomenologia da Percepção (1945), Merleau-Ponty postulava a necessidade de o filósofo acolher generosamente em si o mundo "já dado". Nesse mundo a espessura da carne não deve ser temida como um obstáculo que separa o eu do outro, mas acolhida como um meio de comunicação" (BOSSI, 1989: 82).

O desenho de observação aumenta a nossa percepção do mundo dado. Desenhando minuciosamente cada parte distinta - base e 
bojo - dos cestos kaipó foi possível distingüir no monocromatismo de sua matéria-prima os diversos padrões de trançado utilizados em sua confecção.

O que vemos ao observar um objeto, segundo SCOTT (1979), são as relações visuais; estas apoiam-se em um sistema de relações estruturais que mantém unida a obra e que são completamente independentes do fato de que as vemos. Exemplificando com a abordagem de uma cadeira, afirma: "O tamanho, a forma, sua capacidade de refletir a luz, a disposição das partes e a forma como estão unidas, constituem dito sistema. Essa é a base material das relações visuais que percebemos ao olhar a cadeira... As relações estruturais são sempre específicas e a única maneira de captá-las é estudar desenhos particulares: examinar um determinado pé ou uma determinada juntura em uma determinada cadeira, por exemplo. Por outro lado, as relações visuais são subjetivas, já que dependem da forma em que operam nossas percepções sensoriais e nossa mente" (SCOTT, 1979: 9).

Nos Kaipó, uma vez conscientes da diversidade de padrões de trançado desse tipo de cesto, passamos a investigar as suas relações estruturais através do estudo de sua tecnologia, isto é, através do estudo do trançado em si.

À falta de matéria-prima original - talas da folha da palmeira buriti - improvisamos "talas" de papel Canson e experimentalmente as trançamos. 
Ao discorrer sobre as ligações entre a técnica e a matéria, FOCILLON (1982) nos esclarece que a técnica tomada como veículo da transformação da matéria é não apenas o que possibilitou a forma, mas o processo que a criou". "Ao encarar a técnica como um processo e, tentanto reconstruí-la como tal, temos a possibilidade de ultrapassar os fenômenos de superfície e de captar as relações profundas" (FONCILLON, 1988: 62)..

O estudo da tecnologia empregada no fabrico do Kaipó nos permitiu, além de conhecer objetivamente como suas partes foram formadas, distinguir nos padrões de trançados os necessários à confecção da forma em si daqueles opcionais, fruto das necessidades Krahó ligadas a outras esferas que não a dos procedimentos técnicos.

Com esses seguros dados etnográficos fomos ao campo, isto é, ao encontro dos Krahó na ânsia de aprender sobre suas necessidades ou, em outras palavras, esclarecer o que fabricavam ao tecerem um cesto Kaipó.

Os Krahó nos ensinaram principalmente o que é para eles um trançado, mas pouco puderam ensinar sobre as especificidades do cesto Kaipó, pois como se expressaram: "só de antigo se fazia Kaipó, hoje não faz mais".

Nosso estudo voltou-se, então, para nossas próprias possibilidades. Felizmente há consistentes pesquisas sobre os Krahó e a utilização dessa bibliografia nos permitiu trabalhar algumas questões. 
De fato, fabricar um Kaipó era mais do que transformar folhas de palmeira em recipiente, era, no mínimo, satisfazer necessidades de manutenção dessa sociedade, expressar vínculos sociais e estar coerente com a ordenação dual presente em tantas outras esferas da sociedade Krahó.

Além dessas constatacões há as questões relativas ao uso e seleção de determinados padrões do trançado do Kaipó feita pelos Krahó, que permaneceram em aberto devido aos caminhos tomados pela sociedade Krahó.

Parece-nos que tais resultados confirmam a adequação do uso do desenho de observação e da reconstrução da técnica como meio de abordagem não apenas do cesto Kaipó, mas de outros ítens de cultura material. Basta que o pesquisador tenha vontade de aprender e usar a linguagem visual.

Em nosso estudo a linguagem visual mostrou-se também um meio adequado de transmitir os processos tecnológicos: tentamos ao invés de descrevê-los com palavras - tarefa que parece mais complicar do que auxiliar na comunicação - mostrá-los com desenhos.

Referindo-se às descrições visuais dos quadros etnográficos holandeses do Brasil setecentista, WHITEHEAD (1988) afirma: "Foi essencialmente pela disciplina do desenho que a descrição visual se desenvolveu tão além da descrição verbal. As palavras conferiam (e ainda 0 fazem) significado às coisas observadas, mas mesmo Marcgraf, excelente observador que era, 
tinha de estacar diante de coisas para as quais não existiam termos. De fato, as coisas muitas vezes escapam da percepção até que as palavras sejam inventadas. $\mathrm{O}$ desenho e a pintura também têm o seu vocabulário e não escapam inteiramente dessa dificuldade, mas, por tradição, a invenção faz parte do ofício" (WHITEHEAD, 1988: 285).

Parece-nos que, de modo semelhante, as descrições visuais dos processos tecnológicos são mais eficazes do que as descrições verbais, porque, nestas últimas, à falta de termos específicos, usa-se como referenciais séries de direções e posições do processo tecnológico descrito; ao contrário, na descrição visual a disciplina do desenho obriga à seleção consciente e observação atenta dos detalhes, garantindo clareza à descrição do processo tecnológico. 


\section{I - $\underline{\text { KROU-RO: A MATÉRIA-PRIMA DO KAIPÓ }}$}

"O Buriti (Mauritia vinifera), um dos mais belos produtos do mundo das plantas, eleva alto nos ares o seu caule simples, coluna de 100 a 120 pés de altura, enfeitado com o grande penacho dos leques de suas folhas...

... Tão encantadora é a paisagem constituída por esses palmeirais, reunidas em bosque, quanto é perigoso internar-se o viajante no meio deles, pois é o habitat da gigantesca cobra sucuriú (Boa murina, L.), que, segundo a afirmação do Padre Nogueira Duarte, atinge às vezes a tão colossal comprimento que estendida quieta no capim, à primeira vista, parece um tronco de palmeira, tombado ao chão".

SPIX e MARTIUS, Viagem pelo Brasil: 1817-1820, 1938: 88.

$\mathrm{Na}$ aldeia de Cachoeira a tarde cai. Lentamente o sol vai se escondendo no poente, destacando os contornos das plantas, das mulheres com suas cuias e crianças nos caminhos do ribeirão e das famílias que retornam das roças, atravessando em fila o pátio: o homem na frente com a espingarda e o Makó pendurados no ombro, a mulher e suas filhas vestidas de saias justas e coloridas, carregando o Papko ou Koro nas costas, suas crianças, seus cachorros... 
É outubro, tempo das chuvas, estamos no meio do rito de Tepyarkwa (festa do peixe). Um homem designado ao papel do boto percorre o caminho circular, passando em frente de todas as casas e, com sua cantoria, anuncia a continuação diária do rito: os homens, divididos em suas respectivas metades, se preparam para a corrida de toras e para a dança no pátio. Estão pintados e enfeitados. Muitas mulheres pegam suas esteiras e sentam-se em frente à sua porta ou nos caminhos radiais, que ligam sua casa ao pátio, para assistirem a essa parte da festa.

Sento-me numa tora de buriti abandonada na periferia do pátio, ao lado de Edvaldo-Pentí, o mesmo homem que está desepenhando o papel de boto e, considero, atenta e admirada, todas os movimentos e cores ao meu redor: corpos luzentes dançam, têm partes pintadas ora de negro, ora de vermelho, tiras verdes, de vegetais são diademas adornando os cabelos negros que escorrem brilhantes sobre os ombros, são colares as pontas verdes que se agitam, pendentes no meio das costas...

Eu pergunto a Edvaldo do que são feitos os enfeites e ele me diz: - Tudo para Tepe e Tere (peixe e lontra) é buriti.

Após a dança, essa sessão do rito está encerrada. Algumas mulheres retornam para suas casas, outras aproveitam para visitar um parente; os homens ainda conversam no pátio, mas a aldeia vai aos poucos adormecendo.

Adormeço; cada vez mais à vontade entre os meus amigos Krahó. 
O sol apenas despontou e a aldeia já está desperta, agitada: há um vai e vem de homens sozinhos e de mulheres em grupinhos, com suas crianças para o banho no ribeirão; um apito no centro chama os homens para a tomada das decisões diárias na praça; as mulheres armazenam água, preparam o beiju matinal, penduram suas esteiras de dormir no varal da casa; caso pretendam ir à roça separam logo um Papko e conversam o tempo todo com suas filhas, irmãs, avós...

Junto-me a elas; ligo-me às mulheres da casa onde habito através da minha Tüi. Ela foi a minha nominadona, isto é, em cerimônia no pátio da aldeia me deu um de seus nomes Krahó. Sou sua Ipantu. Ela age comigo de modo amável, pouco fala, mas seus gestos e ações claramente pretendem me ensinar: certo dia, seu marido trouxe enormes folhas de buriti e ela fez dois ou três cestos Papko e Koró, ensinando-me cada passo de suas confecções. Depois me deu de presente o maior e mais bonito.

Deixo minha Tüi em seus afazeres e percorro a aldeia à procura do cesto Kaipó. Ainda não havia me conformado com a sua ausência. Conheci em um dos lados da aldeia o Sr. Martins e em outro lado o Sr. Messias. Ambos foram nas décadas de 60 e 70 informantes de Júlio Cézar Melatti. Estão velhinhos e somente em suas casas encontrei o pequeno cesto Kaipó pendurado no esteio da casa, sobre as camas. O Sr. Messias quer me contar todos os mitos que contou a Melatti, demora para compreender o que eu queria saber sobre os cestos, mas depois nos entendemos: eu, conformada com a quase ausência do Kaipó, e ele, solícito, passamos alguns dias conversando 
sobre as esteiras, os tipitis, os abanos e os cestos. Todos esses artefatos o Sr. Messias classificou, dizendo: - Tudo é Krou (buriti); tudo é Krou-ro (buriti trançado).

O buriti é um vegetal pertencente à família das palmeiras. Os viajantes do século XIX e os modernos botânicos descrevem o buriti (Mauritia vinifera) com estipe (caule) coluniforme, sem ramificações, medindo até 50 metros de altura e 50 $\mathrm{cm}$ de diâmetro. Possui ao longo centenas de cicatrizes foliares, apresentando, no final, copa desenvolvida com densa folhagem lisa, brilhante e verde escuro. Suas folhas são palmadas ou flabeliformes lembram um leque aberto -, são em número de 20 a 30, de 5 metros de comprimento e até 3 metros de largura. O pecíolo das folhas é longo e convexo na parte de baixo. O limbo da folha é inteiro e pregueado na base. Quando jovem, a folha apresenta-se com os bordos contínuos; ao crescer, as folhas fendem-se em grande número de tiras, rijas nas folhas mais jovens e pendentes nas antigas. Suas flores reunem-se em espádices ramificadas de 2 a 4 metros de comprimento e seus panículos frutíferos igualmente pendem em ramos alternados e dipostos em duas ordens, com frutos arredondados, de 3 a 5 centímetros, cobertos de escamas amarelas e avermelhadas.

O buriti é certamente a matéria-prima fundamental para a sociedade Krahó, pois está presente diariamente em atividades essenciais à sua existência. 
O tempo da sociedade Krahó é marcado, de um lado, pela alternância dos astros sol e lua, trazendo o cotidiano, e de outro, é marcado pelas estações pluviométricas - chuva e seca. A etnografia escrita por Melatti, fruto de suas várias estadas entre os Kahó, nos informa que cada uma das estações do ano é preenchida por diversas espécies de ritos, que acentuam ora as relações entre os homens, ora as relações entre os homens e o meio-ambiente. A mensagem dos ritos se expressa através dos cantos, das danças, gestos, deslocamento espaciais, uso de alimentos, pinturas e artefatos específicos.

O buriti compõe o universo ritual como alimento e matéria-prima para a confecção dos artefatos e das toras. São raros os ritos que não têm início e término com seus participantes masculinos divididos em duas metades e realizando uma corrida ao redor da rua circular da aldeia, carregando, cada uma das metades, sua tora sobre os ombros. Esta tora é o caule do buriti. As dimensões do caule, as pinturas a ele aplicadas, bem como as pessoas encarregadas de seu corte e transformação variam de acordo com o rito a ser realizado.

Conforme o rito também varia o uso dos artefatos. Há os chamados pelos Krahó de enfeites: são os diademas, cintos, pulseiras e colares confeccionados com a folha do buriti. Estes artefatos identificam a metade a que pertence o seu usuário naquele dado rito, recorrendo-se a modificações na forma e antigamente à cor das folhas, uma vez que as folhas novas fornecem artefatos em tom verde-claro e as folhas maduras, em tom verde-escuro. 
O rito Pembkahek põe em evidência os meninos e os jovens que ainda não têm filhos - são chamados de Pembkahek e para a modalidade Katuti é confeccionado com a folha do buriti um tipo de esteira dupla, na qual os jovens escondem-se como reclusos. Trata-se da Katuti (Katu é o nome próprio das esteiras utilizadas sobre os jiraus de dormir e ti é uma partícula aumentativa).

No rito Tepyarkwa e no Ko? Krito usa-se a máscara Ko ? Krito (onde ko significa água e o termo como um todo indica seres ligados à água). Ela é semelhante a duas esteiras de buriti unidas nas laterais, mas a parte inferior termina com as fitas não trançadas cobrindo até os pés o usuário.

Os frutos do buriti são usados num rito que acentua as relações entre homens e mulheres pertencentes a metades opostas através da troca de frutos silvestres, mel ou carne por alimento preparado. Quando o elemento oferecido é o buriti, o rito chama-se Kroutó Mé? Yen (significa procurar buriti). Às vezes, esse mesmo rito tem início com os homens pedindo um cesto às mulheres com quem farão as trocas. Este cesto é o Kopko, feito da folha do buriti e especial para o uso das mulheres em suas atividades de coleta de frutos silvestres. Quando assim se procede, o rito chama-se Kohe'pire (que significa apanhar o cesto).

Antigamente os Krahó praticavam o rito Apiñure, onde expressavam as relações entre os maridos e as esposas. Neste rito, diante das toras de buriti, as mulheres entoavam um cântico, em que mencionavam o cesto kaipó. Trata-se dos seguintes versos: 


\section{"Ampómã ayete kotomã kaeporé \\ O que está pendurado ? será que é kaipó \\ (ré = partícula diminutiva)}

\section{Ampómã ayete kotomã pëtëwëre}

O que está pendurado ? Será que é pëdwo ? (buzina).

Paralelo às atividades rituais - as festas, Amnikhĩ̃, para os Krahó - há o dia-a-dia com suas tarefas ligadas à auto-reprodução. Nessa esfera, o fruto silvestre do buriti é bastante consumido como alimento; as folhas são utilizadas para a cobertura do teto e preenchimento das paredes de suas habitações, e para a confecç̃oode quase todos os artefatos de uso doméstico: o tipiti, o abano para o fogo, as esteiras e os vários tipos de cestos são todos Krou-ro, isto é, buriti trançado.

Atendo-nos aos cestos podemos afirmar que a matériaprima bruta é a folha do buriti, podendo ser transformada em palha ou em tala, dependendo do tipo de cesto.

Com a folha bruta, apenas cortando-se fora o pecíolo na altura do limbo, os Krahó confeccionam os cestos Koho e o Papko. Do limbo extraem, delicadamente, a palha e com ela tecem o Makó. O pecíolo fornece as talas, que darão forma ao Kaipó.

Vimos acima que o pecíolo do buriti é longo e convexo na parte debaixo. É desprendendo-se a epiderme dessa parte inferior, que se obtém a tala, fasquia ou lâmina com dimensões aproximadas de $1 \mathrm{~m}$ por $0,5 \mathrm{~cm}$. A tala é lisa na parte externa e rugosa na interna. A parte lisa aparecerá no exterior do cesto. Ela é rígida e para trançá- 
la é necessário que esteja murcha, umedecida, de preferência pelo sereno.

Um dia, na aldeia de Cachoeira, Edvaldo-Pentí, talvez cansado com a minha insistência em perguntar sobre o kaipó, amavelmente se prontificou a fazer um para mim, para eu ver como "de antigo se fazia o kaipó".

Na manhã seguinte já tinha um feixe de talas de buriti prontas. Sentou-se no chão, colocou umas sobre as outras as primeiras talas que formariam a base do cesto, todas com a parte rugosa voltada para cima e continuou acrescentando-as aos pares, cruzando-as sempre. As talas já estavam um pouco secas, Edvaldo enchia as bochechas de água e borrifava sobre elas. Na porta da casa, vários homens assistiam atentos.

Um quadrado trançado parecia ser já um tamanho bom para a base do cesto. Edvaldo o amarrou nas diagonais, colocou o trabalho no colo, a parte lisa das talas voltada para sua barriga e continuou trançando aos pares. Delineou-se o cesto, a parte rugosa da tala ficou no interior e a parte lisa formou o kaipó brilhante, rígido e verde num tom escuro, avermelhado.

Mas Edvaldo estava insatisfeito. A forma obtida estava um pouco desequilibrada: sua base não assentava bem no plano e as talas deixavam certas incômodas aberturas entre si. Então, com humor e provocando riso na platéia masculina que nos assistia disse 
uma frase em entonação de desabafo. Eu, muito sem graça, perguntei: - O que foi ? E ele, rindo, me traduziu: - Essa coisa nunca deu certo !

Depois terminou o cesto: fez da mesma maneira a tampa e improvisou uma alça com barbante, mal torcido, provavelmente de origem sertaneja. A tarde me chamou, deu-me o kaipó de presente e pediu para eu lhe trazer um pouco de miçangas quando voltasse à aldeia, pois queria "enfeitar sua filha pequena para dar festa".

O kaipó feito por Edvaldo em 1990 é uma pálida sombra dos exemplares coletados entre as décadas de 40 a 60 na aldeia de Pedra Branca e nesta mesma aldeia de CAchoeira. Estes primam pelo domínio da técnica em cada componente do artefato e têm como alça um fino e bem torcido cordel feito de algodão (Gossypium sp.).

As palmeiras de buriti fazem parte da paisagem habitada pelos Krahó. Sabemos tratar-se do cerrado: área caracterizada por uma camada herbárea rasteira com arbustos e pequenas árvores de caules retorcidos e folhas grossas, onde são comuns as matas ciliares - florestas estreitas que margeiam todos os rios - e os buritizais, que se desenvolvem nos brejos, próximos às nascentes dos córregos.

Esta localização fitogeográfica dos buritizais está incorporada na visão que os Krahó têm do universo. 
Segundo a cosmologia Krahó - vide MELATTI (1978) o universo é circular e está dividido em três níveis: há um mundo celeste, que, semelhante à "terra", é habitada por outros índios - "as estrelas são fogueiras desses indios", por gaviões, urubus, mulherestrela (entidade que ensinou a agricultura às mulheres), etc.; há o mundo intermediário, que é a "terra" propriamente dita, onde vivem; e há o mundo subterrâneo, onde vivem os porcos-queixadas, os tatus; por lá passam o sol e a lua antes de despontarem a leste e é um local repleto de buritis, chamado Kroukhoti $(\mathbf{k r o u}=$ buriti, $\mathbf{k h o}=$ coletivo, $\mathbf{t i}=$ grande, isto é, grande buritizal).

Os três níveis do cosmos têm contato entre si. A leste, tanto o mundo celeste e o intermediário se conectam através do pés do céu - são colunas, como o intermediário e o subterrâneo fazem conexão por um buraco.

O cosmos é circundado pela água (Ko), com a cúpula celeste impedindo o seu derramamento; a água divide o mundo intermediário em seco e molhado; na condição de chuva, a água conecta o mundo celeste ao intermediário.

Para além da cúpula celeste, a leste, vivem bichos horríveis como cobras gigantes, lacraias, ratos com chifres, etc.

O conhecimento Krahó do universo está articulado à sua mitologia. Como os Krahó localizam o buriti no mundo subterrâneo e no intermediário, apresento dois mitos que fazem referência aos buritis nesses dois níveis cósmicos. 
O mundo subterrâneo - grande buritizal - é abordado no mito "a história do rapaz que caiu no buraco", que recolhi na aldeia de Cachoeira.

"O rapaz falou pra mãe: - Intxe (mãe), eu vou pra caçada. Aí o rapaz foi e depois ele achou tatu no buraco. Aí cavou, cavou até ele afundou. Caiu em cima do buriti. Aí veio porcoqueixada, é klô e ele falou pro porco-queixada: me desce. Aí andou com porco-queixada. Klô levou rapaz no buraco, prá subir, Klô falou: - Fica aí emcina de Klô, senão Canoti (cobra grande) come você. Aí subiu nas costas de Klô, chegou. Klô falou pro rapaz: - Olha, nesse chapado você pode ir até aldeia. Pronto, rapaz saiu e depois chegou na aldeia. Ei! Rapaz já vem vindo e a mãe chorando" (Sr. Messias, 1990).

A seguir, destaco um trecho do mito que narra as aventuras de Sol e de Lua entre os buritizais do mundo intermediário. Ambos encontram-se em um buritizal. As palmeiras são baixas e Sol e Lua apanham seus frutos com as mãos. Os frutos de Sol são maduros, vermelhos, mas os de Lua, devido a um encantamento feito pelo Sol, são sempre verdes, escuros. Lua se zanga, atira com força um dos frutos no caule do buriti, que imediatamente começa a crescer até atingir a altura atual. Sol afirma então que não se poderá mais apanhar frutos de buriti apenas com as mãos e Lua justifica que assim poderão saber sempre onde há água (NIMUENDAJÙ, 1946). 
Peço licença para nos próximos parágrafos arriscar-me a algumas considerações sobre o material apresentado, visando uma aproximação ao lugar do buriti no pensamento Krahó.

Com os dados etnográficos acima citados construí um modelo visual do cosmos Krahó, obtendo a seguinte forma:

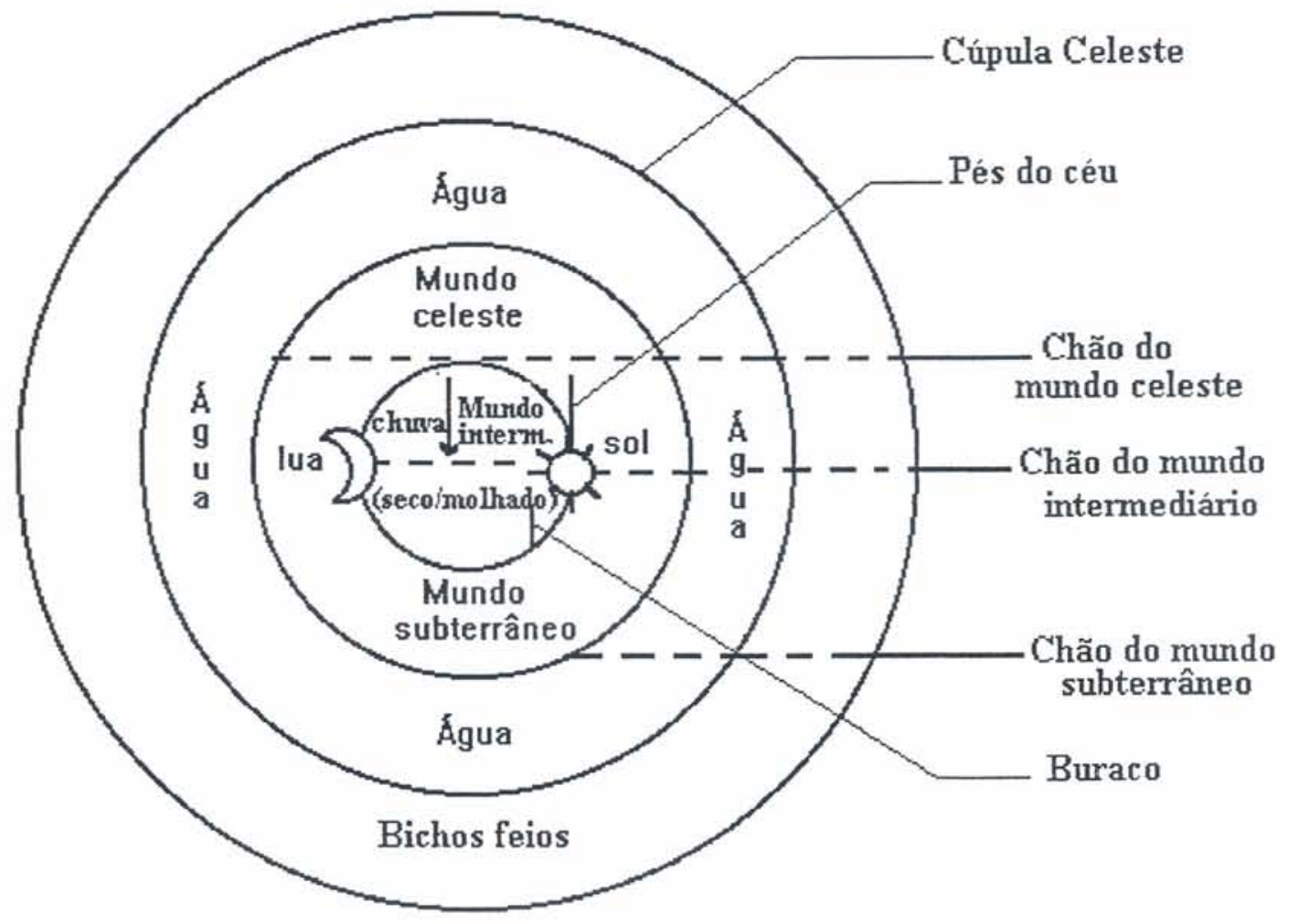

Observamos que o cosmos tem a forma circular, com a espacialidade dada por duas direções: uma horizontal - o chão de cada um dos mundos do universo; e uma vertical, na qual os três mundos se conectam por colunas e buraco.

A água (Ko) está presente na totalidade do espaço. Ela circula o cosmos; ela corre horizontalmente no chão de cada um dos 
mundos: no celeste porque ele é semelhante ao intermediário, que se divide em seco e molhado, e no subterrâneo porque o seu chão está em contato direto com a água que circunda o cosmos; e finalmente, como chuva a água percorre o cosmos na vertical.

Os buritizais do mundo intermediário e os do mundo subterrâneo têm em comum o fato de se localizarem no encontro do elemento terra com o elemento água.

Vimos que no mito de Sol e Lua, a altura atual dos buritis indica a presença de água no local. O que é endossado pelos nossos ecólogos ao afirmarem que o habitat dos buritizais são os brejos das nascentes dos córregos.

No mundo subterrâneo, o chão como um todo está em contato com a água. Tem-se condições para a existência de um grande buritizal, o que é coerente com o seu nome, Kroukhoti.

Se a leitura que fiz desse material for correta, os buritis são vegetais que dependem de quantidades equivalentes de água e terra juntos para viverem, o que os torna especiais para os Krahó.

Os krahó usam o seu sistema de metades - wakmeye e katamye - como categoria de pensamento ordenadora do universo. Nesse sistema os vegetais são classificados segundo dêem flores ou frutos na estação chuvosa ou na estação seca em respectivamente katamye e wakmeye. O buriti, no entanto, vissa o ano todo e é molhado e seco ao mesmo tempo. 
Parece-me que o buriti é um vegetal especial para os krahó porque sintetiza seu sistema de metades, ele é uma unidade. Assim, suas folhas são classificadas quando verdes, inkó, em katamye e quando secas, inkré, em wakmeye; seus frutos, se estão verdes, identificam-se com a cor preta, são katamye, se maduros, com a cor vermelha, são wakmeye; seu caule recebe pinturas específicas que o transforma, o classifica e o relaciona com os homens katamye ou wakmeye, durante as corridas de toras; e na cestaria veremos que há duas direções do trançado do buriti krou-ro, ambas classificadas nesse mesmo sistema de metades. 


\section{II - KAIPÓ ERA O ARMARINHO DA MULHER \\ (Sr. Xavier, Aldeia de Cachoeira, 1990)}

Quando cheguei na aldeia de Cachoeira, os Krahó já haviam sido comunicados, pelo funcionário da FUNAI, que eu viria para fazer um trabalho com "artesanato".

Receberam-me todos no pátio: levaram-me para banhar, deram-me de comer e instalaram-me na casa de Txuc-Txuc, o Parí, isto é, aquele que faz a mediação nos conflitos inter e extra aldeia. $\mathrm{Na}$ mesma tarde, começaram a trazer o "artesanato" para eu ver, trocar, trazer para São Paulo e mesmo vendê-lo.

Uns artefatos eram simplificacões mal sucedidas dos em uso na aldeia, outros foram feitos especialmente para o consumo da nossa sociedade, tais como espanadores de pó e saias de penas de galinhas, para carnaval, segundo os próprios Krahó.

Estava ali a realidade triste para mim acostumada ao belo "design krahó conservado no acervo do museu e para eles ao tomarem ciência de que eu não tinha vindo para trocar o "artesanato" por bens desejados da nossa sociedade e, sim, queria aprender sobre os seus artefatos.

Eu citava Melatti e Manuela Carneiro da Cunha e mais surpresos e confusos eles ficavam, visto que esses amigos thes haviam perguntado sobre suas estórias, suas festas, seus mortos, seus parentes. Citava Gilberto Azanha e Maria Elisa Ladeira e eles os 
associavam às suas lutas contra as opressões exteriores. Felizmente, alguns senhores lembravam-se da época em que Vilma Chiara e Harald Schultz iam com um carro à aldeia e na volta o carregavam com "coisas dos krahó".

Começávamos a nos entender: "coisas dos Krahó" não faziam parte da classificação "artesanato". Para os Krahó artesanato eram os artefatos feitos para a venda à FUNAI e "coisas dos krahó" artefatos confeccionados segundo as suas necessidades de uso. $\mathrm{O}$ meu interesse pelas "coisas dos Krahó" provocou um reconhecimento e acolhimento amistoso da minha pessoa.

A primeira mala de artesanato que me mostraram naquela tarde pertencia ao Sr. Xavier - o homem mais velho da casa onde me hospedaram; logo ele se prontificou a me ensinar "as coisas dos krahó". No dia seguinte, levou-me para sentar na sua cama, trouxe-me os seus belos colares, pulseiras, apitos, cintos e passamos horas conversando sobre o mundo maravilhoso que permeia cada um daqueles artefatos. Quando lhe perguntei sobre os cestos e mais especificamente sobre o cesto kaipó, o Sr. Xavier o definiu, dizendo: - "kaipó ? kaipó... era o armarinho da mulher; para guardar os trens...". A informação seguinte, no entanto, foi desanimadora: - "só de antigo se fazia kaipó, hoje não faz mais" .

De fato, durante o período que permaneci na área dos krahó, com exceção de dois exemplares, não vi os kaipó. Mas, vi o seu substituto em pleno uso: tratava-se de tamanhos diferentes de 
latas circulares, como as que acondicionam tinta para parede, leite em pó, castanha de caju, etc.

O kaipó era um cesto confeccionado pelos homens para uso exclusivo das mulheres.

Qual a utilidade desse cesto, ou o que guardava esse "armarinho", antigamente, na forma de kaipó e, em 1990, como latinhas de folha-de-flandres?

Vamos tentar responder a esta questão através das fichas de identificação dos kaipó do acervo do Museu Paulista, da bibliografia pertinente e de minhas observações em campo.

Nos anos 60, a antropóloga Thekla Hartmann fez um trabalho de identificação dos kaipó do citado acervo, contando como informante com o índio Krahó, Pokró.

É interessante e necessário - porque acreditamos que tal procedimento faça parte da crítica às fontes - citar aqui, a seguinte observação sobre o informante Pokró. Thekla Hartmann nos esclareceu, pessoalmente, que em certa viagem de Vilma Chiara às aldeias Krahó, Pokró foi acusado de grande mentiroso e de sem validade as suas informações. Intrigas entre grupos na aldeia ou não, corremos o risco de estarmos trabalhando com informações menos verdadeiras; no entanto, e isso é interessante, como nos alertou Thekla Hartmann, se houve a mentira ela se elaborou com certa coerência e diríamos, segundo esse estudo, dentro de categorias do pensamento Krahó. 
Em 1990 conheci Pokró na aldeia de Manoel Alves. Eu estava ali de passagem, assistindo a um rito de reintrodução de uma jovem à vida social; havia passado a noite acordada, atenta às muitas e concomitantes atividades da aldeia: foi possível apenas breves recordações sobre a época e as pessoas envolvidas no trabalho com o acervo do Museu Paulista.

Voltemos, portanto, às informações que constam das fichas museográficas. Podemos contar com a identificação completa de vinte e sete exemplares de kaipó, onde obtemos dados sobre dimensões, matéria-prima, formato, utilidade, uso e sexo do artesão.

As respostas dadas por Pakró à questão da utilidade do kaipó chamaram-nos a atenção em dois aspectos:

Em primeiro lugar, sua resposta variava segundo o kaipó. Serviam sempre para guardar algo, mas o quê ? Às vezes só alimentos ou só miudezas, outras vezes combinando esses itens excludentes com cocos, ou seja, alimentos e cocos ou miudezas e cocos, e ainda associando cocos com o urucu (Bixa orellana).

Em segundo lugar, porque ao fazer a distinção entre cocos e alimentos, Pokró, evidentemente, não estava considerando coco uma espécie de alimento, como a nós é próprio.

A partir de então, duas questões tornaram-se pertinentes: qual teria sido o critério usado por Pokró para classificar os kaipó segundo a utilidade, e o que é coco para os Krahó. 
Para respondê-las consideramos apenas os cestos usados por mulheres adultas e buscamos as relações possíveis entre os elementos variáveis do kaipó e sua utilidade. A variedade dos kaipó é dada pelo formato da base - quadrangulares ou retangulares; pelos padrões do trançado presentes na base e no bojo dos cestos - são quinze padrões de bases e quatorze de bojos; e pelas dimensões variáveis entre 26 a $8 \mathrm{~cm}$ de altura por 18 a 66 de circuferência.

A Tabela 1 mostra as variantes formais do kaipó e sua utilidade de acordo com as fichas museográficas. 


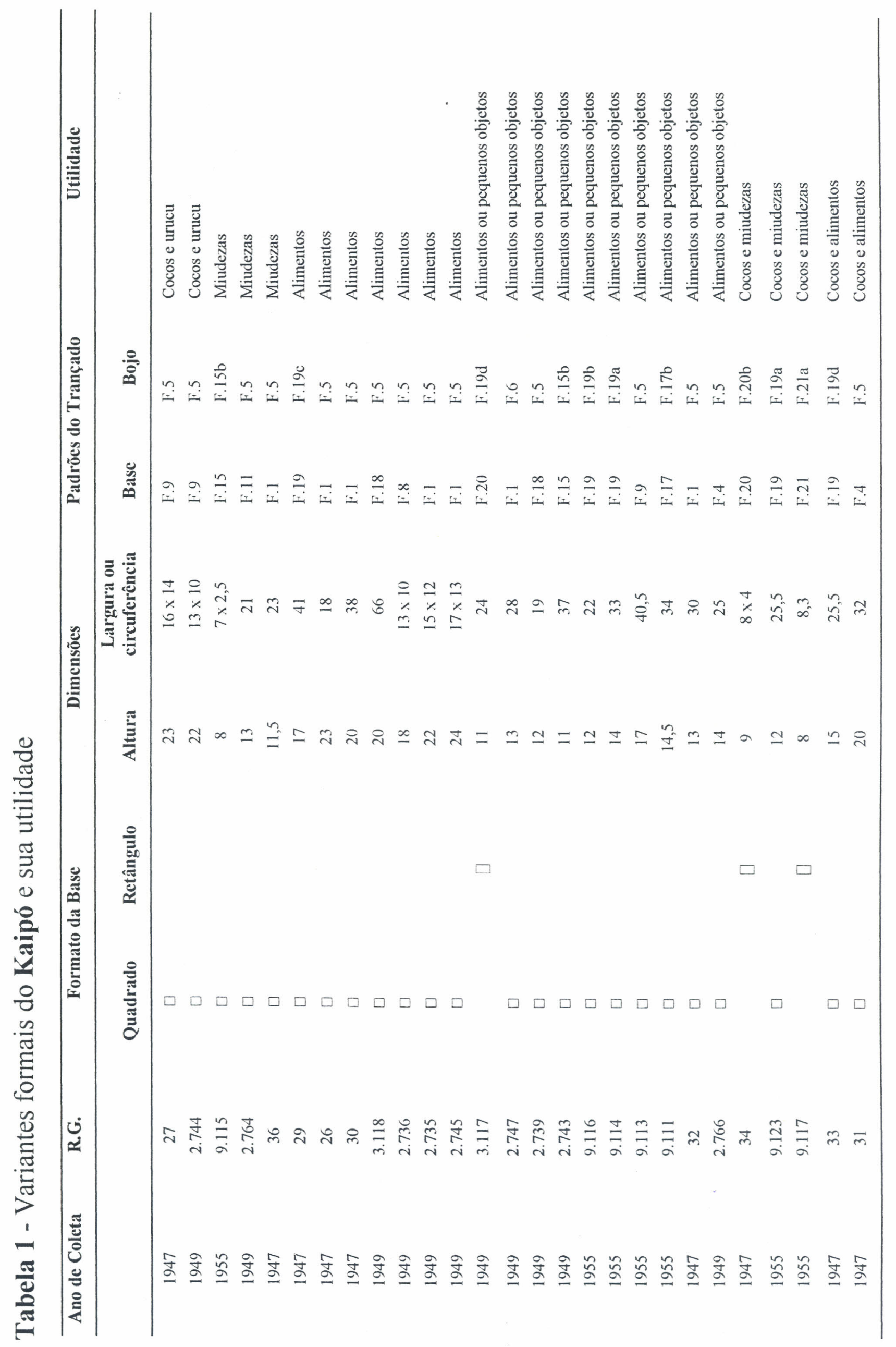


Relacionando a altura dos kaipó com suas utilidades, observamos um critério geral perpassando os dados.

Tabela 2 - A altura e as utilidades do kaipó

\begin{tabular}{cl}
\hline $\begin{array}{c}\text { Altura } \\
\text { (em ordem crescente) }\end{array}$ & \multicolumn{1}{c}{ Utilidades } \\
\hline 8 & Miudezas \\
9 & Miudezas e Cocos \\
10 & - Miudezas ou Alimentos \\
11 & Miudezas ou Alimentos, Cocos \\
12 & Miudezas ou Alimentos \\
13 & Miudezas ou Alimentos \\
14 & Alimentos e Cocos \\
15 & - Miudezas ou Alimentos \\
16 & Alimentos \\
17 & ------- \\
18 & Alimentos e Cocos \\
19 & ----------- \\
20 & Alimentos, Cocos e Urucu \\
21 & Alimentos, Cocos e Urucu \\
22 & Alimenos \\
23 & \\
24 & \\
\hline
\end{tabular}

A tabela acima evidencia esse critério geral: os cestos maiores que $17 \mathrm{~cm}$ de altura - os mais altos - guardavam alimentos, cocos e urucu, aqueles com dimensões entre 17 a $10 \mathrm{~cm}$ de altura - os 
medianos - guardavam além de alimentos e de cocos, as miudezas e os cestos menores que $10 \mathrm{~cm}$ - os mais baixos - somente miudezas e cocos.

Uma vez que os Kaipó são sempre mais altos do que largos e que em campo observei que em substituição ao Kaipó os Krahó estavam usando latas circulares de três tamanhos diferentes, parece-me que podemos traduzir esse critério geral usando uma nomenclatura nossa, que relativiza e adjetiva objetos de mesmo tipo, segundo seus tamanhos. Nesses termos, temos o seguinte resumo do critério geral usado por Pokró:

- Cestos grandes guardavam alimentos, cocos e urucu.

- Cestos médios guardavam alimentos, miudezas e cocos.

- Cestos pequenos guardavam miudezas e cocos.

Com esse critério geral a questão da utilidade dos Kaipó fica parcialmente respondida, pois o informante Pokró foi muito mais específico na sua classificação.

Podemos afirmar, por exemplo, que um kaipó pequeno não guardava alimentos, só miudezas e cocos; no entanto, se observarmos os dados fornecidos por Pokró, notamos que há cestos pequenos específicos para miudezas e outros específicos para cocos e miudezas juntos.

Aqui se coloca, agora, em um outro nível, a questão do critério para essa sutil classificação. 
Levanto a hipótese que tal critério passava pela leitura do conteúdo dos padrões existentes no bojo e na base dos Kaipó.

O estudo dos Kaipó através da confecção experimental desses cestos e da análise dos exemplares que fazem parte do acervo do Museu Paulista mostram que um Kaipó pode ser iniciado pelos Krahó de quinze maneiras diferentes e que seu bojo pode ser confeccionado de quatorze maneiras, determinando uma série de padrões distintos.

Em campo, os Krahó me ensinaram que cada artefato trançado tem padrões que the são específicos. A quase ausência dos Kaipó em campo contribuiu para sabermos muito pouco sobre o valor expressivo desses padrões específicos. Nesse estudo, portanto, foi possível relacionar apenas o aspecto formal desses padrões com a utilidade, o que não nos permitiu chegar a nenhuma conclusão por esse caminho. Apesar disso, parece-me interessante assinalar a semelhança entre a grande quantidade de opções na confecção de um Kaipó, determinando seus padrões e a grande especificidade no que toca à sua utilidade.

Em continuação à questão da utilidade do Kaipó, consideremos a distinção entre alimentos e cocos feita pelos Krahó, segundo os dados fornecidos por Pokró. 
O que é coco para os Krahó ? Coco é o fruto da palmeira babaçu (Orbignia $s p$ ), como nos informa NIMUENDAJÙ (1946) referindo-se à coleta de frutos silvestres entre os Timbira.

O coco de babaçu "pode atingir até $15 \mathrm{~cm}$ de diâmetro longitudianal, encerrando 3 a 4 sementes oblongas, delagadas, oleaginosas, de 6 a $7 \mathrm{~cm}$. de comprimento" (CORREA, 1926: 227).

Essas sementes embora possam ser comidas, entre os Krahó geralmente não o são, porque além de serem de difícil obtenção, o seu uso não alimentício é muito importante.

NIMUENDAJÙ (1946) refere-se às notas de Pohl sobre uma guerra entre os Krahó e os Põrekamekra, onde o que estava em disputa era a posse do babaçu de determinada região.

Segundo MELATTI (1978), "o babaçu não é quase consumido pelos Krahó, que não o possuem em seu território; guardam suas amêndoas, que obtém mais longe, presas por um fio de algodão e as usam menos para comê-las do que para produzir o sumo com que fixam a tinta de urucu ao corpo. Fervem também as amendôas em água, retirando o óleo que flutua sobre ela, que usam nos cabelos" (MELATTI, 1978: 41). Acrescentando dados, NIMUENDAJÙ (1946), WUSTMANN (1958) e BALDUS (1962) nos informam que o coco de babaçu seccionado ao meio transforma-se em um carimbo, usado para pintura corporal com matéria corante obtida do carvão misturado com a seiva do pau-de-leite. 
Durante minha permanência na Aldeia de Cachoeira presenciei por três ou quatro vezes, no início da noite, as pessoas da casa onde eu estava hospedada ficarem bem quietas e aguçando os ouvidos, dizerem: - É Kupem... é kupem que vai chegar" (Kupem = termo que nos designa de modo geral). Pouco depois chegaram uns poucos sertanejos com um burrinho carregando dois cofos nas ancas, cheio de "coisas para trocar". Não assisti a nenhuma dessas transações, mas em uma da vezes vi, no outro dia, em várias casas, vasilhas com uma boa quantidade de sementes de babaçu, obtidas via esses sertanejos. Algumas eram furtivamente comidas, deixando no ar uma evidente auto-censura: elas seriam transformadas em óleo ou oportunamente usadas para se obter a tinta de urucu.

O óleo extraído das sementes de babaçu é usado para dar forma aos cabelos. Os cabelos compõem o que denominam "jeito certo de ser krahó".

$\mathrm{Na}$ aldeia, nuitas pessoas estavam com os cabelos compridos até os ombros, mas com a parte de cima curta e com um sulco, formado pelo cabelo bem aparado à altura da metade da testa, em torno da cabeça, interrompendo-o na parte de trás. Os cabelos eram considerados bonitos - impéi - quando estavam de acordo com o "jeito certo de ser Krahó", isto é, deviam ter o citado corte e estarem lisos e brilhantes, efeitos conseguidos com o óleo de babaçu.

Mas também para a pele do corpo as sementes de babaçu são importantes. Certa tarde, como parte das atividades do Tépyarkwa (a festa do peixe), dentro de uma das casas, uma moça 
foi pintada por uma mulher. A jovem ficou o tempo todo de pé, imóvel, apenas mastigando as sementes de babaçu, cujo sumo cuspia na palma da mão da pintora, que embolando a pasta de urucu, a amolecia. Molhando a outra mão nessa tinta já bem homogênea, a pintora fez listras horizontais no corpo todo da jovem.

No centro da aldeia, no pátio, os homens estavam todos adornados e muitos exibiam padrões de pintura corporal. A metade Tere é monolítica, isto é, todos são lontras: tinham o corpo inteiro até o meio das canelas pintados de negro e na altura dos ombros, formando uma espécie de pala, o vermelho de urucu. A metade Tep é formada de inúmeras espécies de peixes: mostravam variados padrões em vermelho e negro na pintura do corpo, que correspondiam aos diferentes peixes.

A jovem que fora pintada no interior de uma das casas juntou-se aos homens no pátio e participou dos cantos e danças. Edvaldo- Pentí me informou: "- Ela dança pintada junto de Tep porque é a mulher do peixe".

Tanto NIMUENDAJÙ (1946) como CUNHA (1978) nos dão a dimensão da importância do coco-de-babaçu, como matériaprima para atividades que fabricam o corpo humano. NIMUENDAJÙ (1946: 52) nos informa que "os próprios índios e todas as coisas que possuem são mais ou menos vermelhas com urucu, .... a tinta de urucu deleita a narina dos índios não menos que a cor vermelha agrada os seus olhos... Além de possuir virtudes antissépticas e profiláticas". CUNHA $(1978: 53,54)$ nos informou que "O urucu, com efeito, não é 
tida como "pintura", mas como "tintura", e os Krahó usam verbos diferentes para "pintar" com jenipapo ou pau-de-leite, hôg, e "tingir" com urucu, kukra. A pintura propriamente dita é o desenho preto feito com jenipapo ou pó de carvão aplicado sobre a seiva do pau-de leite, e nos interstícios do qual se espalha o vermelho de urucu". ...."Não cortar o cabelo e abster-se de pinturas corporais, restrições que são sempre concomitantes, significam, em todos os contextos, não participar da vida pública. Assim, foi-nos dito certa feita, os homens mais velhos não pintam o corpo, apenas braços, pernas e rosto já que ficam sentados às portas das casas, de lá exortando os corredores de toras e os participantes nos riturais. Pela mesma razão, asseguram-nos então, não se pinta a criança até ela sair ao pátio, apenas se a tinge com urucu".

Parece-me que essa seleção de dados etnográficos já nos permitem concluir o que é coco para os Krahó e avaliar a sua importância para essa sociedade. O coco de babaçu é utilizado prioritariamente para dar forma aos cabelos e para colorir a pele, quer como componente da tinta de urucu, quer como um carimbo. O coco de babaçu relaciona-se à corporalidade dos Krahó; é a matéria-prima para se fabricar aspectos da pessoa krahó. A distinção entre cocos e alimentos, que nos parecia incoerente, é lógica. Os Kaipó guardavam de modo bastante específico coco-de-babaçu, miudezas e alimentos.

A questão da utilidade do Kaipó ainda não se esgotou. Sabemos que os termos alimentos e miudezas são gerais, podendo abarcar uma série imensa de ítens sob essas denominações. Parece- 
me, portanto, que resta esclarecer quais as miudezas e alimentos se relacionavam ao Kaipó.

No acervo etnográfico do Museu Paulista inventariei 22 tipos de cestos Krahó. Em campo observei que, naquela oportunidade, havia apenas quatro tipos de cestos em uso na aldeia. Tratava-se dos tipos Papko, Kohó, Makó e do quase inexistente Kaipó. Também como recipientes vi latas, malas, caixas de papelão e cestos provenientes de outros grupos indígenas Timbira ou de sertanejos; esses cestos eram classificados pelo Krahó da seguinte maneira: - "É cofo, não é coisa de Krahó".

Atenho-me, a seguir, aos dados procedentes de minha estada entre os Krahó. São apenas observações não sistemáticas de campo, mesmo assim opto por abordá-las porque, como veremos, permitirão integrar a utilidade com outros aspectos do Kaipó.

Em campo, relacionados a miudezas havia o cesto Makó e as latinhas cilíndricas.

Os cestos Makó são de uso exclusivo dos homens, para guardarem as suas miudezas: anzóis, linhas de pesca, fumo, cachimbo, etc.

Em quase todas as casas observei latinhas cilíndricas compondo o arsenal de artefatos domésticos. Em duas ocasiões pude observar claramente a sua utilidade e uso; pertenciam às mulheres que nelas guardavam suas miudezas: vi pinça para depilação, tesoura e um Akór, colar de tiririca (Cyperus rotundus) em fase de confecção. 
Quanto ao aspecto utilidade e uso, essas latinhas estavam substituindo o cesto Kaipó. Logo, podemos afirmar que as miudezas guardadas no kaipó, assim como o coco-de-babaçu, também se relacionavam à corporalidade dos Krahó.

Relacionados a alimentos havia dois tipos de cestos: os Papko e os Kohó. Ambos são de uso exclusivo das mulheres; os Papko são utilizados para transportar e armazenar os alimentos trazidos da roça e os Kohó apenas para transportar alimentos encontrados no caminho ou para a coleta dos frutos silvestres.

Embora tanto a coleta e a manipulação dos vegetais cultiváveis como o uso desses cestos sejam tarefas femininas, a posse e a distribuição desse alimento é coletiva, isto é, no cotidiano, ele é consumido por todos os habitantes da casa e, se armazenado em um Papkó, pode ser assediado por qualquer pessoa da casa.

Em campo, minha zelosa Tui mais de uma vez me ofereceu alimentos que estavam fora do esquema de armazenagem, preparo e consumo coletivo da casa. Ao dar-me um pedaço de mamão ou um pedaço de fígado de veado cozido e seco, seu gesto rápido e na ausência da maioria dos membros e transeuntes da casa tinha algo de super estimação e posse individual do alimento.

Parece-me que o Kaipó está relacionado a esse tipo de alimento, que chamarei de iguaria, embora não tenha visto a sua armazenagem em nenhum recipiente. 
A afirmação acima baseia-se principalmente no caráter pessoal da posse dessas iguarias. Veremos que o kaipó era um cesto feminino e individual, logo, guardava ítens - alimentos, cocos e miudezas - considerados bens particulares de uma mulher.

Para demonstrar o caráter individual do kaipó, abordaremos aspectos de sua forma e o modo de ser usado.

O kaipó é um cesto de base quadrada ou retangular, de onde sobe perpendicularmente o bojo de paredes firmes, dada a rigidez das talas de buriti. Possui uma tampa que se sobrepõe parcialmente ao bojo em uma proporção de 1:3. Essa tampa corre através de um cordel de algodão lateral.

Em campo observei o modo como estavam sendo usados os dois únicos exemplares de kaipó presentes e as latas circulares, suas substitutas.

Contrariamente às minhas expectativas, o cordel de algodão não servia para pendurar o kaipó nos ombros; aliás, um kaipó nunca é usado dessa maneira. Ele fica penduardo no esteio da casa, sobre a cama de sua proprietária; quando esta vai ausentar-se por mais tempo, ela o transporta dentro de um Papko ou o enlaça com um dos braços.

Quando Edvaldo-Pentí teceu um kaipó para mim, algumas mulheres na aldeia e, particularmente a minha Tui, ensinaram-me a fazer o que chamavam de "nó de kaipó": sobredobrando o cordel em cima da tampa, faziam um nó de onde 
pendiam duas alças, as quais serviam para pendurar o kaipó. Ela me informou: " - Esse nó serve para guardar as coisas, aí ninguém mexe; se mexer fica sabendo porque uma não consegue fazer igualzinho estava feito".

O kaipó era portanto um cesto individual. Os ítens que guardava eram bens particulares, uma vez que ficavam protegidos do assédio de outras mulheres pela tampa e pelo nó de kaipó.

O caráter também particular do alimento, comentado acima, faz-me concluir que os alimentos guardados no kaipó eram, provavelmente, as iguarias.

Os kaipó guardavam então: iguarias; miudezas tais como pinças para depilação, tiririca para a confecção do colar Acor e tesouras; e coco-de-babaçu para a obtenção de carimbos, óleo de babaçu e tinta-de-urucu.

O fato dos bens guardados no kaipó serem de posse particular não significa que eram usufruídos apenas pela dona do kaipó.

Como indicamos acima, temos poucos dados etnográficos relativos aos alimentos guardados no kaipó, logo não podemos abordar a sua circulação entre as pessoas. Por outro lado, tratando-se dos demais ítens, podemos afirmar que eram bens usufruídos por outras pessoas, mas tendo a proprietária do kaipó e seus pertences como a mediadora desse consumo. 
Tomemos as miudezas e o coco-de-babaçu. Vimos que pinças para depilação, tesouras, tinta-se-urucu, óleo de babaçu, carimbos, tiririca para o colar Akor são todos instrumentos relacionados a ações sobre o corpo humano. Os atos de depilar o corpo, cortar e cuidar dos cabelos, tingir ou pintar a pele, confeccionar o colar Akor são aspectos da construção da pessoa Krahó elaborados exclusivamente pela mulheres que trabalham o corpo de suas crianças, das mulheres e especialmente dos homens seus parentes, conforme observei em campo e documenta amplamente a bibliografia sobre os Krahó.

$\mathrm{Na}$ aldeia de Cachoeira, enquanto tecia um kaipó para mim, Edvaldo-Pentí me informou: " - De antigo, todo homem fazia kaipó para a mulher... era o marido que fazia para a esposa. Se não podia fazer, pedia para irmão dele, avô, tio, mas só parente podia fazer". Na mesma época, mas em outra oportunidade, o Sr. Messias se referiu ao mesmo assunto nos seguintes termos: "O kaipó só marido podia fazer, outro não; se outro fizesse, aí era para comprar".

Nos dados acima assinalamos que o kaipó de uma mulher era tecido pelo seu marido e em último caso pelos seus parentes afins masculinos por parte desse casamento e à pedido do marido.

Segundo a bibliografia sobre os kaipó os termos de parentesco marido Impien e esposa, Iprõ, são usados por mais de um par de indivíduos. Para cada homem há as esposas potenciais, as 
esposas classificatórias e a esposa-real; vice e versa para cada mulher. Para qual dessas esposas um homem tecia um Kaipó ?

A respeito das esposas potenciais, MELATTI (1978) nos informa: "cada homem chama de "esposa" todas as mulheres com quem acha que pode ter relações sexuais. E geralmente chega a ter relações sexuais com grande número delas, pois, apesar do casamento ser monogâmico, os homens e mulheres solteiros têm plena liberdade sexual, e aos indivíduos casados se oferecem muitas ocasiões em que podem manter relações extraconjugais" (MELATTI, 1978: 53). "Um Krahó só evita relações sexuais com as parentas mais próximas, entre as quais inclui todas as mulheres nascidas no seu segmento residencial original. Assim, cada indivíduo traça mais ou menos arbitrariamente os limites do seu grupo de parentes consangüíneos, dentro do qual estão necessariamente os indivíduos nascidos no mesmo segmento residencial em que ele também nasceu" (MELATTI, 1978: 54).

Sobre as esposas classificatórias, LADEIRA (1982) nos esclarece que entre os krahó os termos do parentesco estão ligados ao mecanismo de transmissão dos nomes pessoais. No ato de dar nome a uma pessoa, o par ideal de nominadores é formado pelos irmãos de sexo oposto: o irmão dá seu nome para o filho da irmã e, por sua vez, a irmã dá seu nome para a filha do irmão. Estabelece-se a relação nominador-nominado expressa pelos termos de parentesco Keti e Ipantu ou a relação nominadora-nominada nos termos Tüi e Ipantu. Uma vez recebido o nome possoal acarretará pertencer a uma das metades Wakmeye e Katamye; ter determinados amigos formais e 
estabelecer formas de relacionameno designados por termos de parentesco. No caso dos termos de parentesco marido, Impien e esposa, Iprõ, um homem chama de esposa a todas as mulheres casadas com homens que possuem o seu mesmo nome. Essas chamamos de esposas classificatórias. A esposa real é aquela com quem um homem não só mantém relações sexuais, mas coabita.

Para qual dessas esposas um homem tecia um Kaipó ?

O kaipó é um objeto concreto e confeccionado com a tala do buriti, que lhe confere longevidade; logo, ele expressava de modo visível e duradouro a relação marido-esposa. Sua presença tornava evidente, isto é, pública essa relação, o que entre os khahó implicava em assumir as regras sociais daí decorrentes.

A bibliografia sobre os grupos indígenas Jê e especialmente sobre os Krahó já abordou profundamente as questões relacionadas às alianças matrimoniais nessas sociedades. Sabemos que o casamento uxorilocal introduz um conflito entre parentes consangüíneos e afins, uma vez que o homem sai da sua casa de origem e passa a morar na casa de sua esposa, onde obedece ordens e presta serviços para um grupo que lhe é alheio: o pai e os irmãos de sua esposa. Esse relacionamento conflitante só se resolve gradualmente, na medida em que o sogro fica mais velho e os cunhados ao se casarem, mudam-se, permitindo a esse marido tomar decisÕes representativas dessa casa. Decorre dessa situação que um jovem evita ao máximo tornar pública a sua relação afetiva com uma jovem e o casamento normalmente torna-se efetivo apenas após o 
nascimento do primeiro filho do casal, momento em que passam a coabitar na casa de origem da esposa.

Referindo-se às prestações de serviços que um homem deve efetuar ao se casar ou ao se relacionar sexual e publicamente com uma mulher. MELATTI (1978) afirma: "O marido é um perene devedor, que paga os serviços sexuais da esposa, seus serviços de cozinha, seu trabalho doméstico, com presentes a seus parentes e também com serviços" (MELATTI, 1978: 53). "De fato, tudo o que um afim faz por um indivíduo deve ser retribuído: alimentos que venham a oferecer, um corte de cabelo, o choro por um parente morto"... "Essas prestações não ocorrem apenas no caso de matrimônios efetivos, mas também fazem parte das relações fora do casamento. Se um homem deflora uma moça, deve dar bons presentes aos parentes dela; se tem relações sexuais com determinadas mulheres está sujeito a prestar pequenos serviços ou dar presentes quando for solicitado" (MELATTI, 1978: 55).

Nesse contexto, um kaipó só poderia ser tecido nos relacionamentos marido-esposa públicos ou nos relacionamentos em que se desejasse torná-los públicos e efetivos. eram as esposas classificatórias e a esposa real que se encontravam enquadradas nessas situações.

Vimos que um homem adquire esposas classificatórias através da nominação e é através do casamento monogâmico que os Krahó adquirem a esposa real. Podemos verificar que em ambos os casos há aquisição de parentes afins. 
Ao abordar o sistema de parentesco entre os Timbira, LADEIRA (1982) afirma: "o que define a composição dos segmentos residenciais é a relação mãe/filha/irmãs e as questões com que se defrontam são com quem casar ?, com quem trocar nome ? - questões que conduzem e orientam as relações entre os grupos que fazem a vida cotidiana de uma aldeia Timbira" (LADEIRA, 1982: 7).

Por esse prisma, adquirir parentes afins significa estabelecer laços sociais que interferem nas decisões da comunidade.

Assim, seja o kaipó tecido apenas para a esposa real ou seja tecido para todas as esposas classificatórias ele indicava, em ambos os casos, a aliança social.

Até o momento esboçamos respostas considerando os aspectos formais mais evidentes do kaipó; mas o kaipó apresenta ainda aspectos bem sutis em seu conteúdo formal. Possui textura visual dada pelo entrecruzamento das talas lisas e brilhantes do buriti cruzadas aos pares, em duas direções. Em cada uma das direções, a luz permite-nos ver duas texturas e, jogando com essa qualidade, o artesão tece diferentes padrões de trançado na superfície do cesto. Através da seleção de técnicas de trançado os Krahó estruturam o cesto kaipó. 


\section{III - ANÁLISE VISUAL DA TECNOLOGIA DO KAIPÓ}

Passa a seguir à minha tentativa de descrever as técnicas do traçado do Kaipó por meios visuais, embricanco, ao mesmo tempo, dados provenientes de contextos diferentes: coleções de museus, observações de campo e confecção experimental.

Todos os cestos Kaipó são iniciados pela base.Selecionei a base representada na figura 1 para iniciar estas descrições por esta ocorrer com grande freqüência em minha amostra - corresponde a 34\% dos Kaipó examinados. Uma segunda razão presidiu a essa escolha: o precário Kaipó que, em campo, um dos informantes confeccionou a meu pedido, corresponde a esse tipo. Finalmente, os meus trabalhos de confeccão experimental de Kaipó mostraram ser esta base a de feitura mais fácil, pois, desde o primeiro passo, as fasquias seguram-se mútua e uniformemente, de modo que mãos e dedos ficam livres para trançarem.

No centro externo desta base vemos uma configuração que lembra uma cruz: é o ponto de partida para a confecção do cesto.

Há nos Kaipó uma variedade de começos. Os tipos em cruz são obtidos pelo entrecruzamento de duas fasquias como é mostrado na figura 2. À primeira vista este começo não parece corresponder ao que é mostrado na figura maior. Tal impressão resulta da direção em que correm as fasquias - em diagonal - e que 
deu origem ao termo utilizado no jargão da tecnologia cesteira - o trançado em diagonal. Trata-se de um termo que pretende privilegiar o processo de construção do trançado, mas que neste caso advém de uma percepção visual.

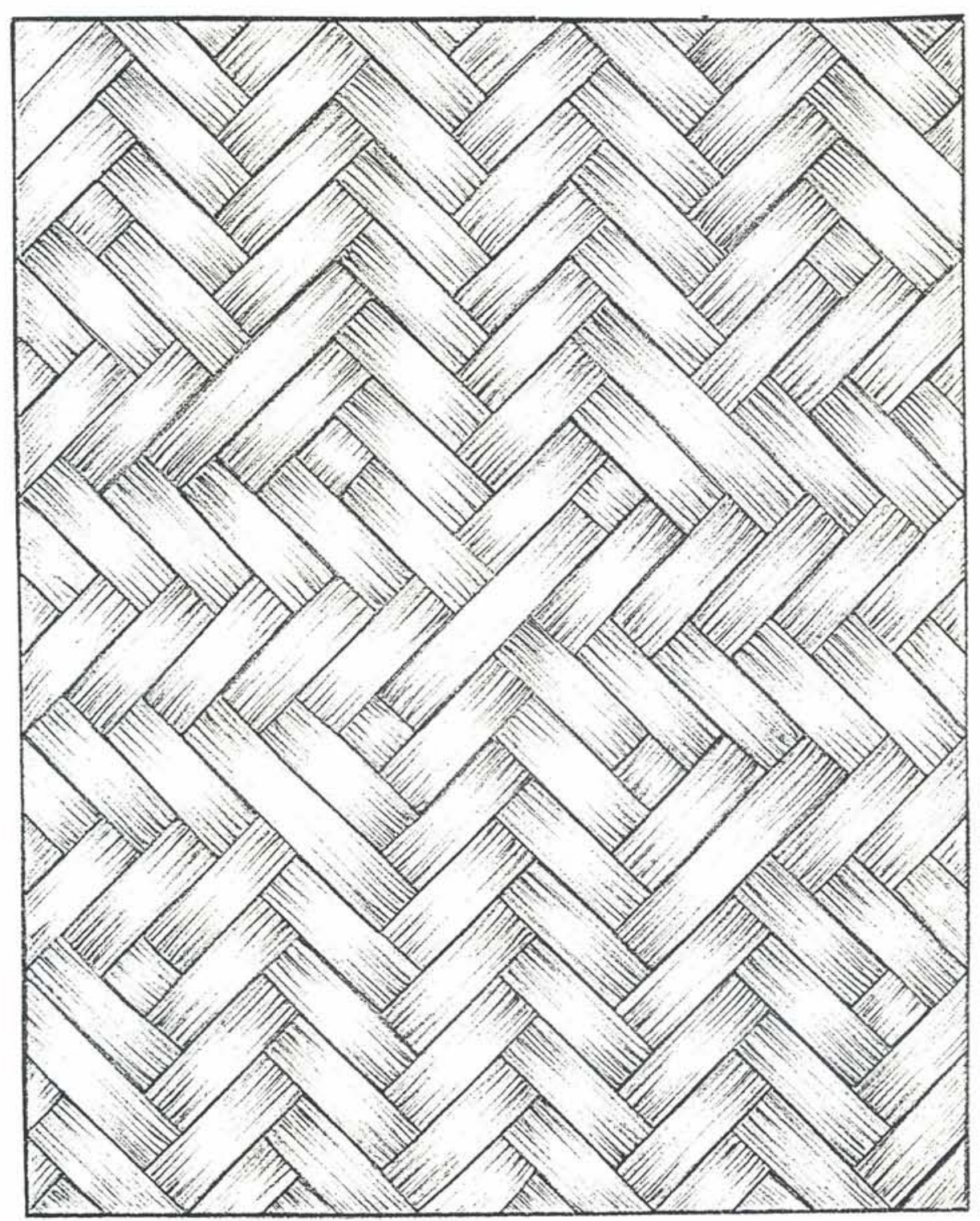

Figura 1 - Base do cesto Kaipó. 


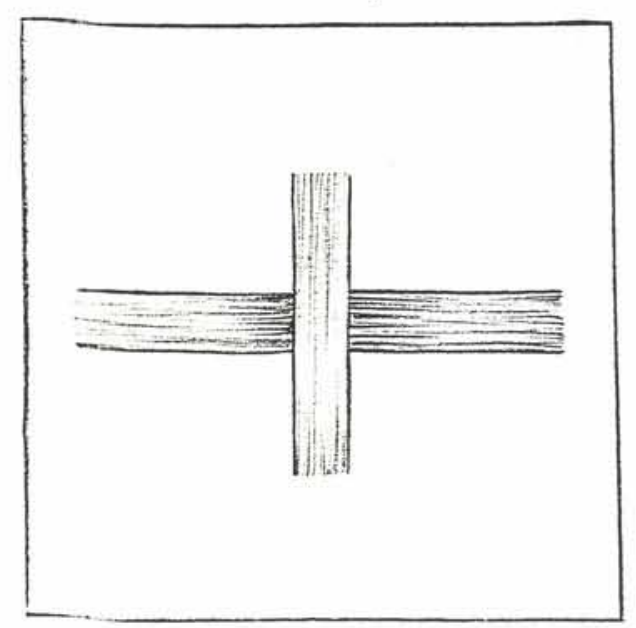

Figura 2 - Disposiçiòo das fasquias no início da confecção.

Em campo, ao iniciarem um Kaipó para mim, os Krahó da aldeia de Cachoeira colocaram as primeiras duas fasquias do trançado tal como ilustrado na figura 2 e continuaram o trabalho aplicando as demaıs fasquias sempre em ângulo reto com as iniciais. E não poderia ser dıferente: se o início da base fosse já com trançado em diagonal, as bordas do cesto não seriam retas, pois cada lado formaria um linha .nngular; por sua vez, se o trançado que se iniciou em ângulos retos continuasse sempre assim, o bojo não seria em diagonal e sim rew). Para a obtenção de bojos com trançado em diagonal e borda rita, como são todos os Kaipó, é necessário o procedimento ilustrado na figura 3. 

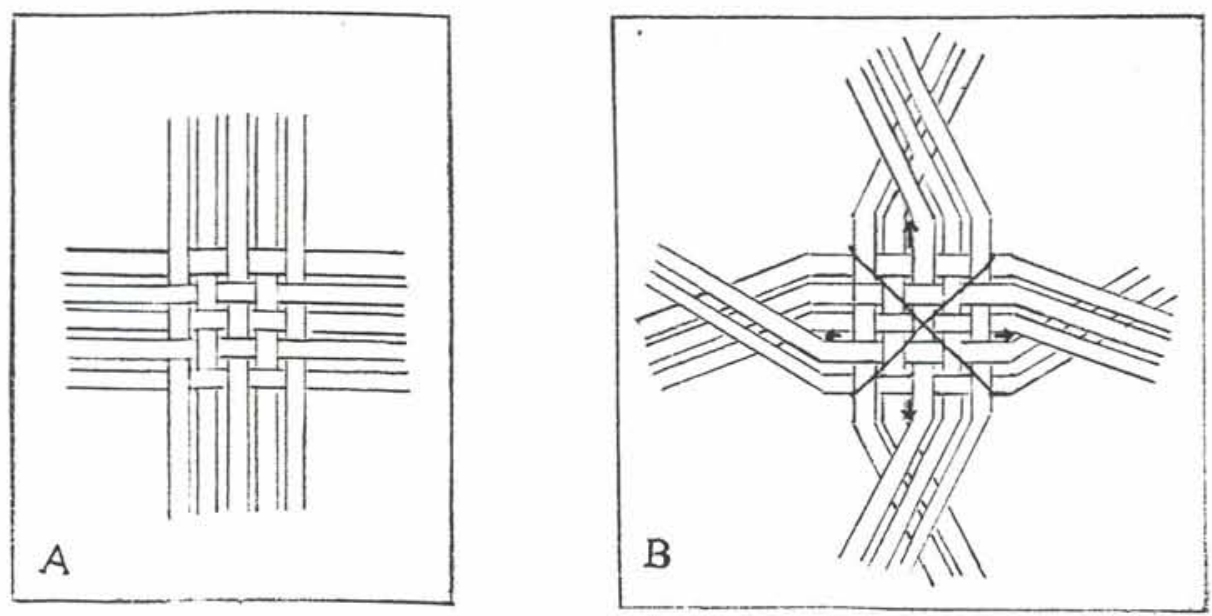

Figura 3 - Conexão entre base, bojo e borda do Kaipó:

A. Trançado da Base.

B. Com o auxílio de um cordel que segura as talas da base, inicia-se a formação dos cantos do cesto $(\uparrow)$ e do trançado em diagonal.

Notamos que para a construção de um cesto de forma quadrada ou retangular do tipo do Kaipó, pode-se usar o trançado reto, os Krahó bem o sabem, porém optam para sua construção pelo trançado em diagonal.

Esta categoria de trançado apresenta uma textura dupla, uma vez que para formar o tecido as fasquias sempre se sobrepõem. Como conscqüência, o trançado possui frente e verso que nem sempre são iguais. Quando diferentes, determinados padrões são usados indistintamente pelos krahó. 
A figura 4 mostra o verso da base apresentada na figura 1 . Este verso também é usado como frente, correspondendo a $8 \%$ de minha amostra. No centro vemos uma configuração que a literatura pertinente denomina de "começo em diamante"; em campo, os Krahó esclareceram-me que a esta configuração chamam de buraquinho, icreré, e que ao outro lado chamam de inchado, rontòtu.

As duas, bem como todas as outras formas de começo de Kaipó, constituem, para os Krahó, iroc, enfeites. São, porém, enfeites próprios, exclusivos desses tipo de cesto.

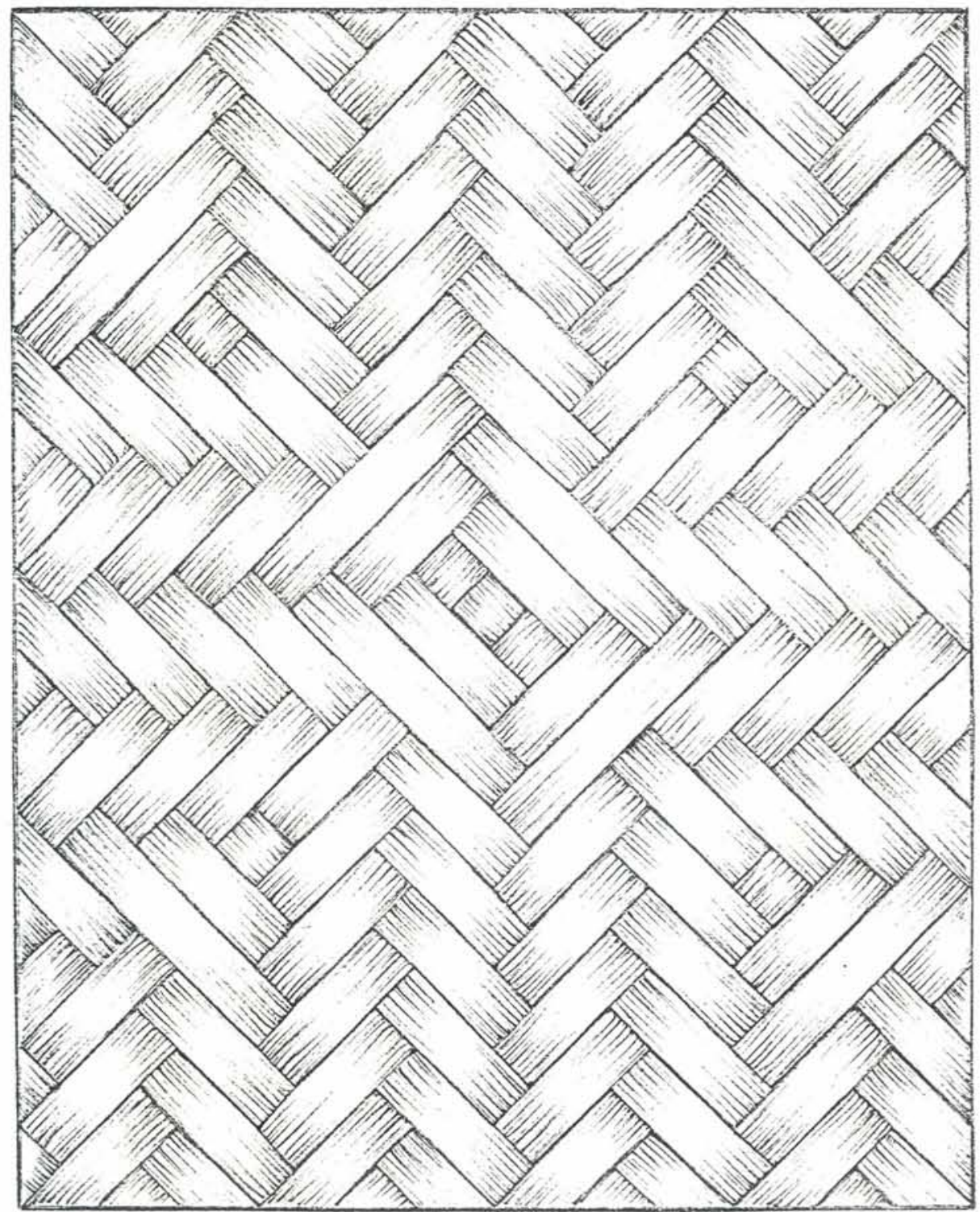

Figura 4 - Base de Kaipó. 
A base e o bojo dos cestos são tecnicamente interdependentes: o tipo de começo que o cesteiro adota determina certas características no bojo.

Observando-se as bases já apresentadas nas figuras 1 e 4 notamos que do ponto inicial do trançado destas bases - umbigo, segundo a terminologia proposta por Berta Ribeiro - vão se formando duas linhas perpendiculares entre si a partir de um trançado claramente regular, isto é, com as fasquias entrecruzandose sempre a um mesmo intervalo.

A mesma regularidade - intervalo - é encontrada nos bojos próprios desses tipos de base. A partir das linhas perpendiculares, base e bojo formam um continum de mesmo tipo de trançado.

A figura 5 representa um bojo comum às bases acima ilustradas, mas não apenas: todos os Kaipó com bases cujo número e disposição inicial das figuras determinam esse mesmo intervalo nas linhas que partem do umbigo, apresentam esse tipo de bojo. Por esse motivo ele está presente em minha amostra com $33 \%$.

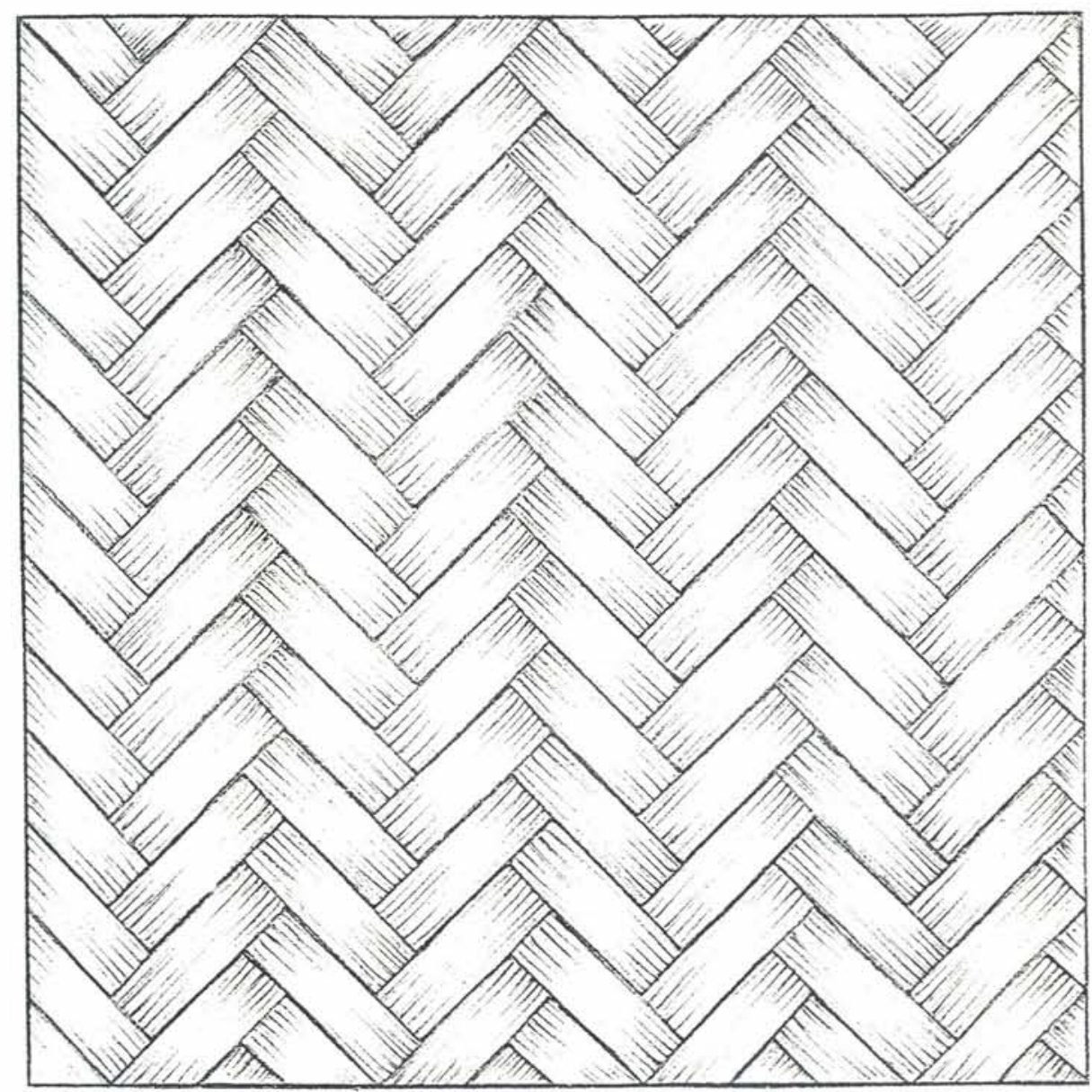

Figura 5 - Bojo de Kaipó. 


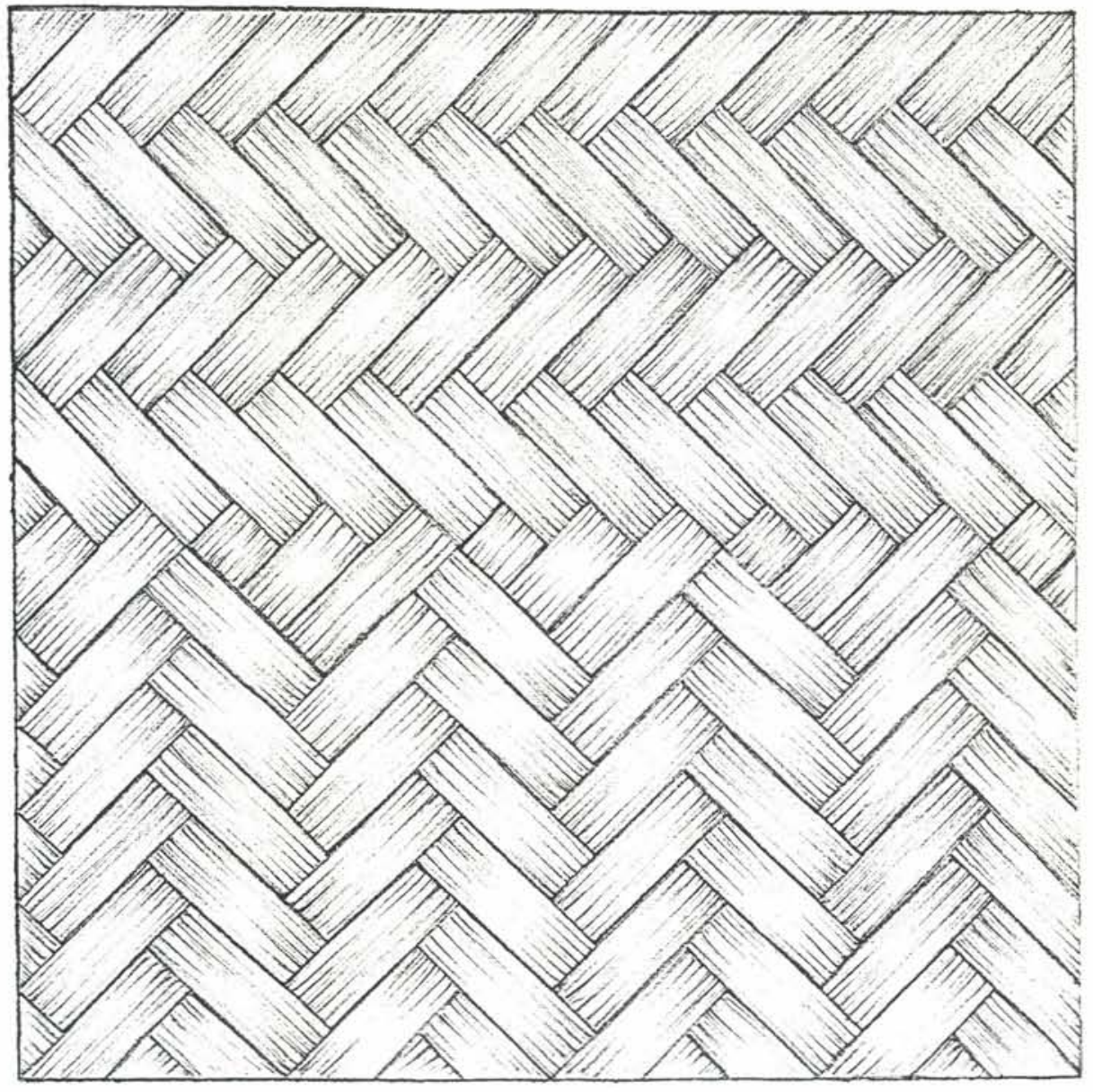

Figura 6 - Bojo do Kaipó.

O bojo representado na figura 6 coresponde a $7 \%$ da amostragem e em campo foi o tipo confeccionado para mim. Nele notamos na parte inferior o trançado exigido pelo tipo de começo, depois uma faixa mediana e novamente um trançado regular, com o mesmo intervalo anterior, mas com um sentido diferente.

O trançado em diagonal apresenta-se visualmente em duas direções: na parte inferior a direção vertical e na parte superior a direção horizontal. A faixa intercalada é decorrente da técnica 
necessária para a inversão do sentido do tranádo. Os Krahó a denominaram Aican ietxo, isto é, passagem.

No caso deste bojo a inversão do trançado foi feita na região mediana por opção do cesteiro, mas esta inversão necessariamente aconteceria, senão nesse local, nas proximidades da borda do cesto, a fim de possibilitar confecção do remate do cesto.

Para rematar o cesto Kaipó o cesteiro Krahó dobra a tala sobre si mesma com uma leve torção e a encaixa na próxima tala. Este procedimento só resulta em uma borda reta quando o trançado é na direção horizontal, pois na direção vertical a borda obtida é uma linha quebrada, um "zigue-zague".

Há dois tipos de remates de Kaipó porque o trançado em diagnoal possui uma textura dupla, possibilitando ao cesteiro cortar uma das talas e dobrá-la, obtendo uma ourela simples, bastante fina e áspera; ou dobrar ambas as talas, obtendo uma ourela dupla, mais grossa e macia ao toque. 
Apresento a seguir uma série de bases de Kaipó: a frente e seus respectivos versos.

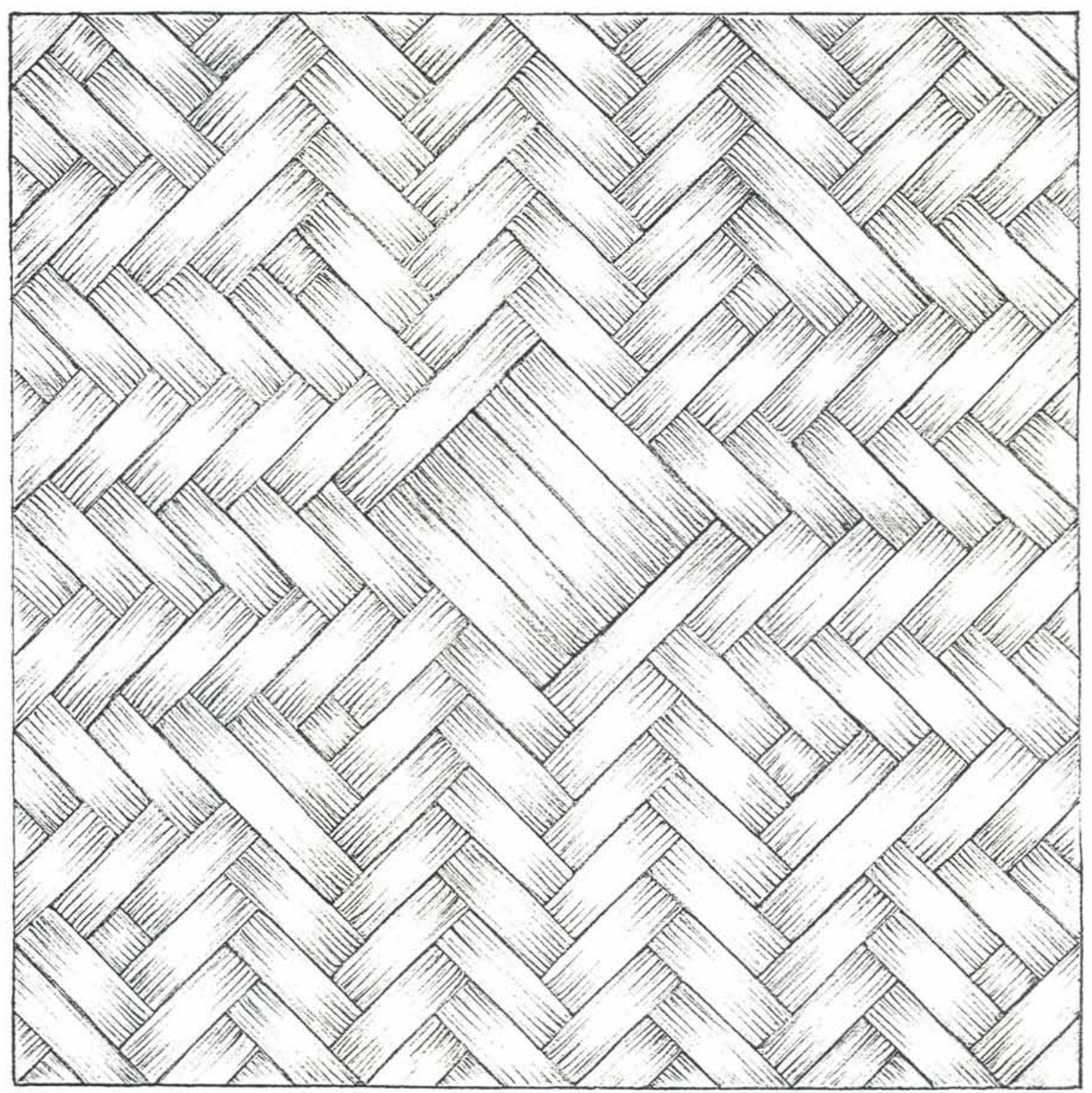

Figura 7 - Base de Kaipó: frente - R.G. n² 27. 


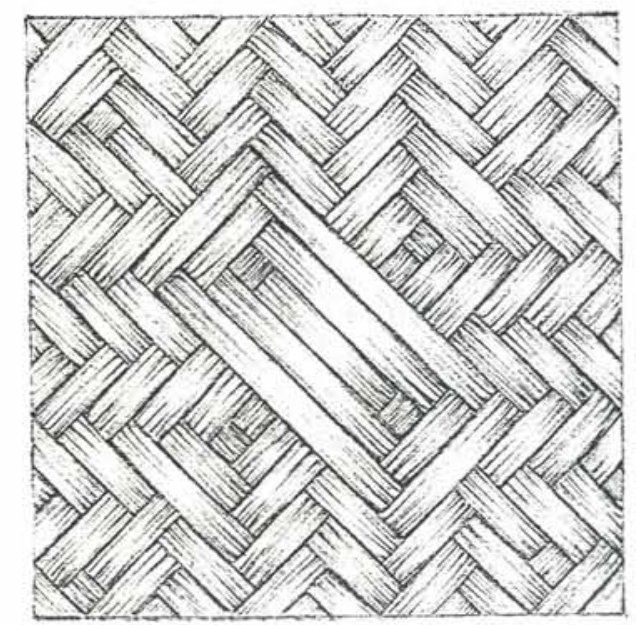

Figura 7a - Base de Kaipó: verso - R.G. n 27. 


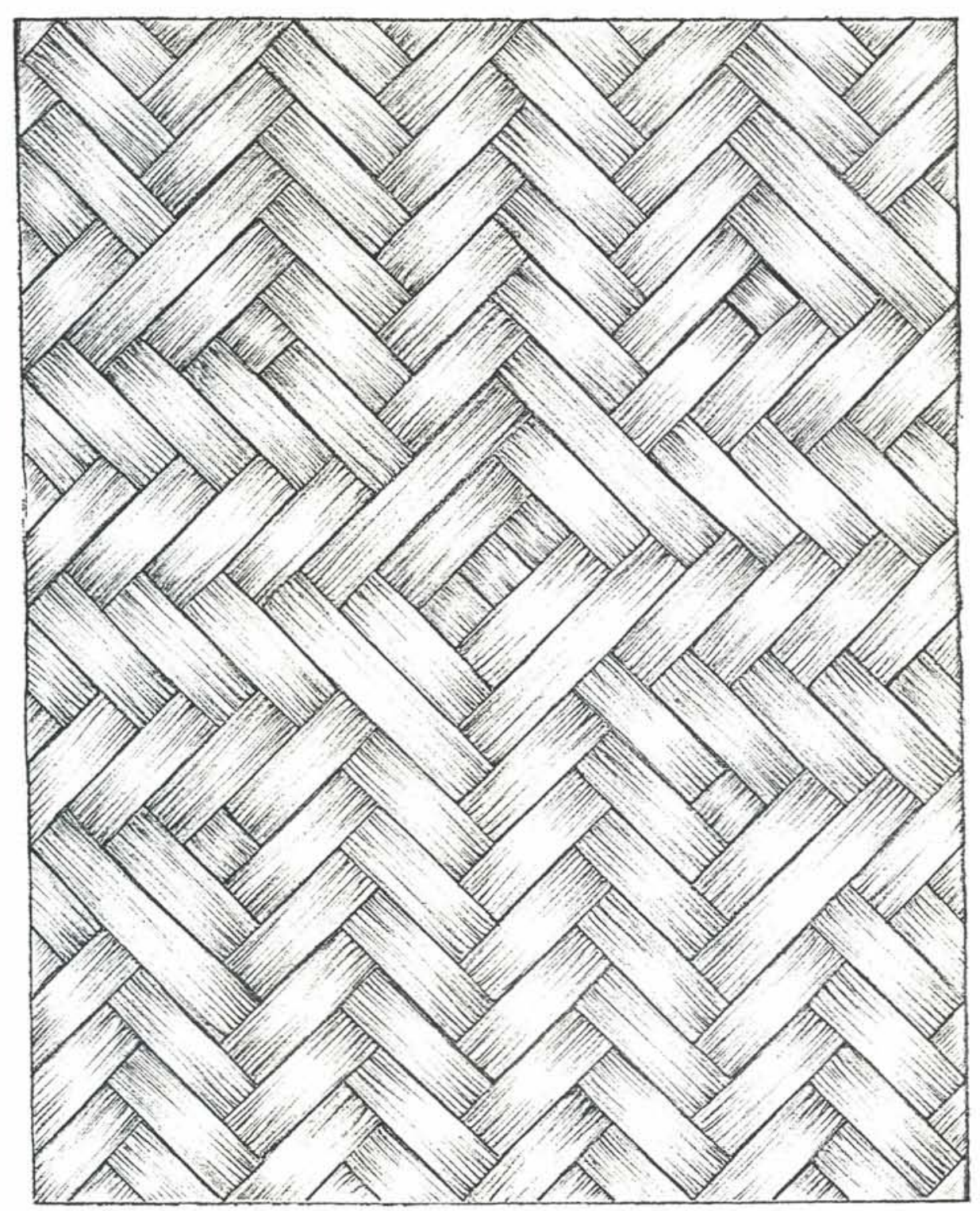

Figura 8 - Base de Kaipó: frente - R.G. nº 2736. 


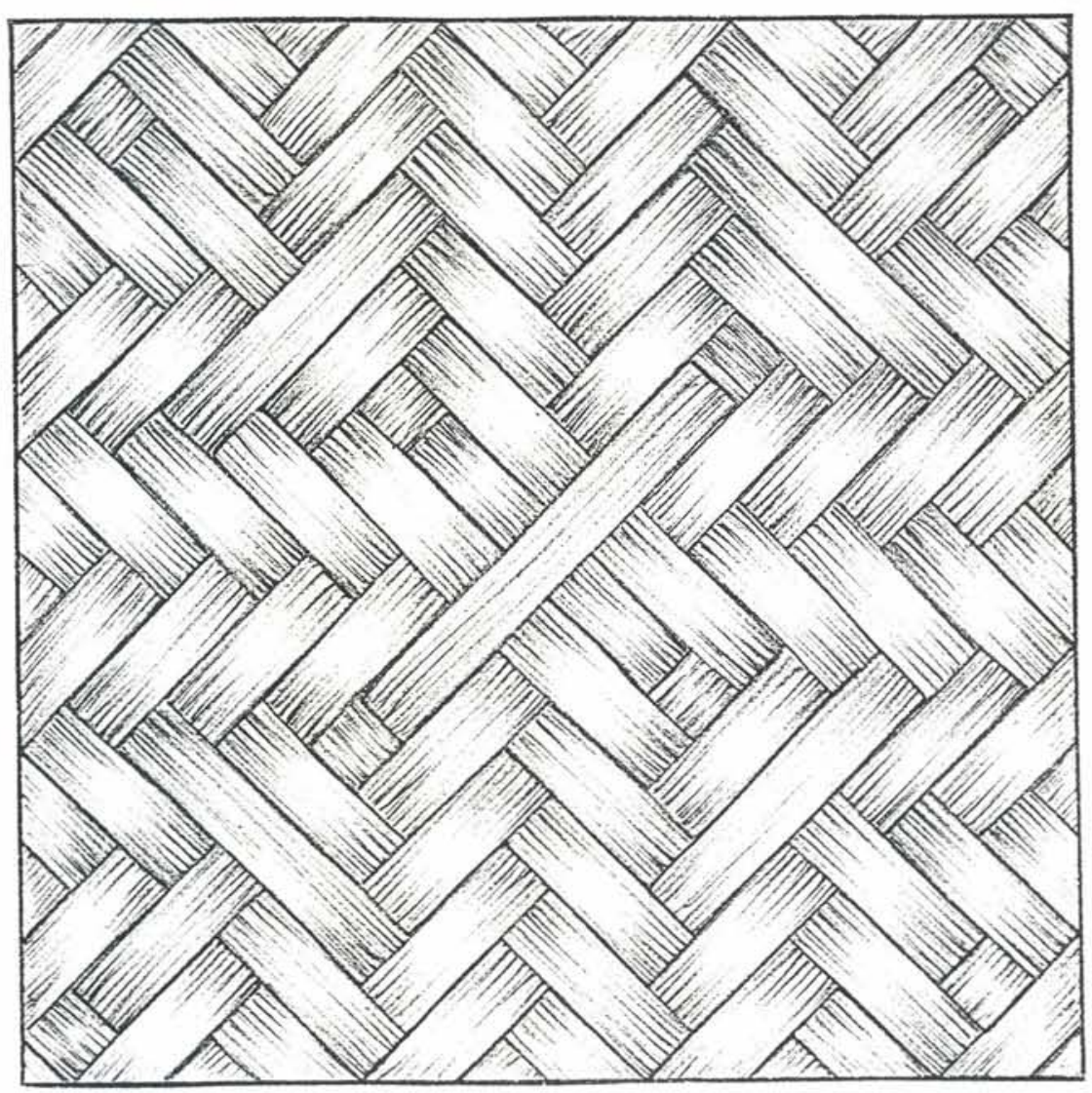

Figura 8a - Base de Kaipó: verso - R.G. nº 2736. 


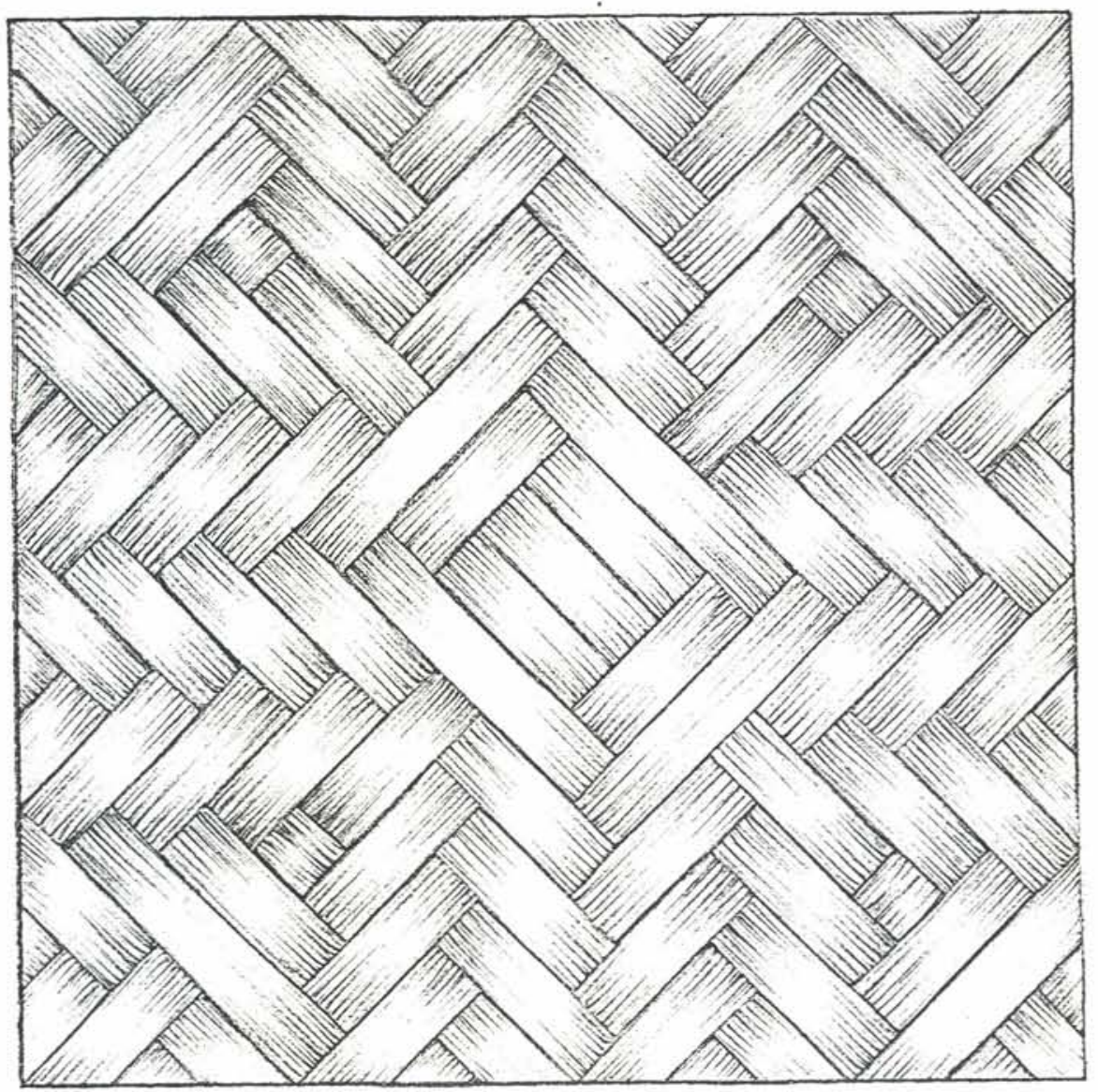

Figura 9 - Base de Kaipó: frente - R.G. nº 10290. 


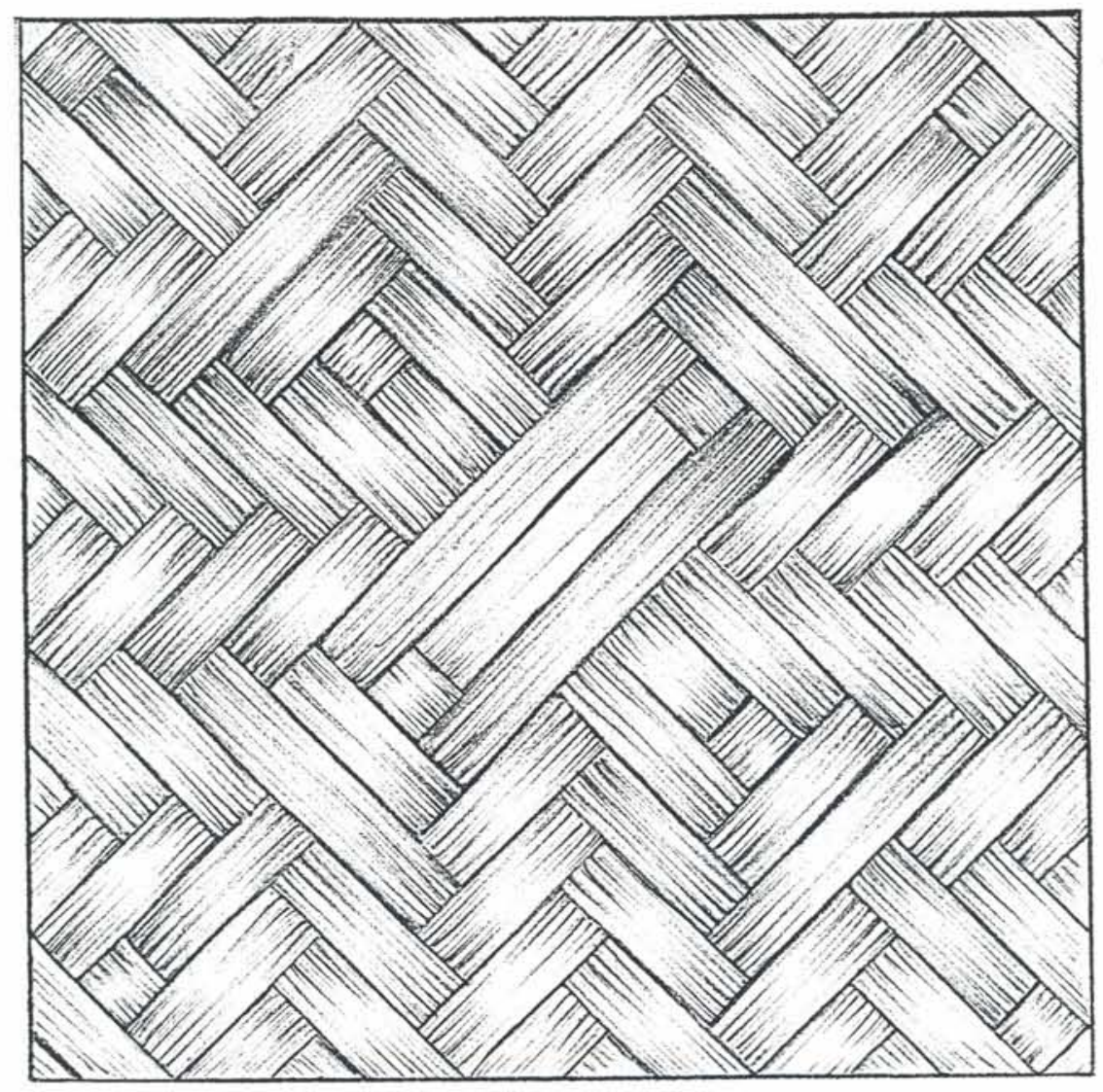

Figura 9a - Base de Kaipó: verso - R.G. n 10290. 


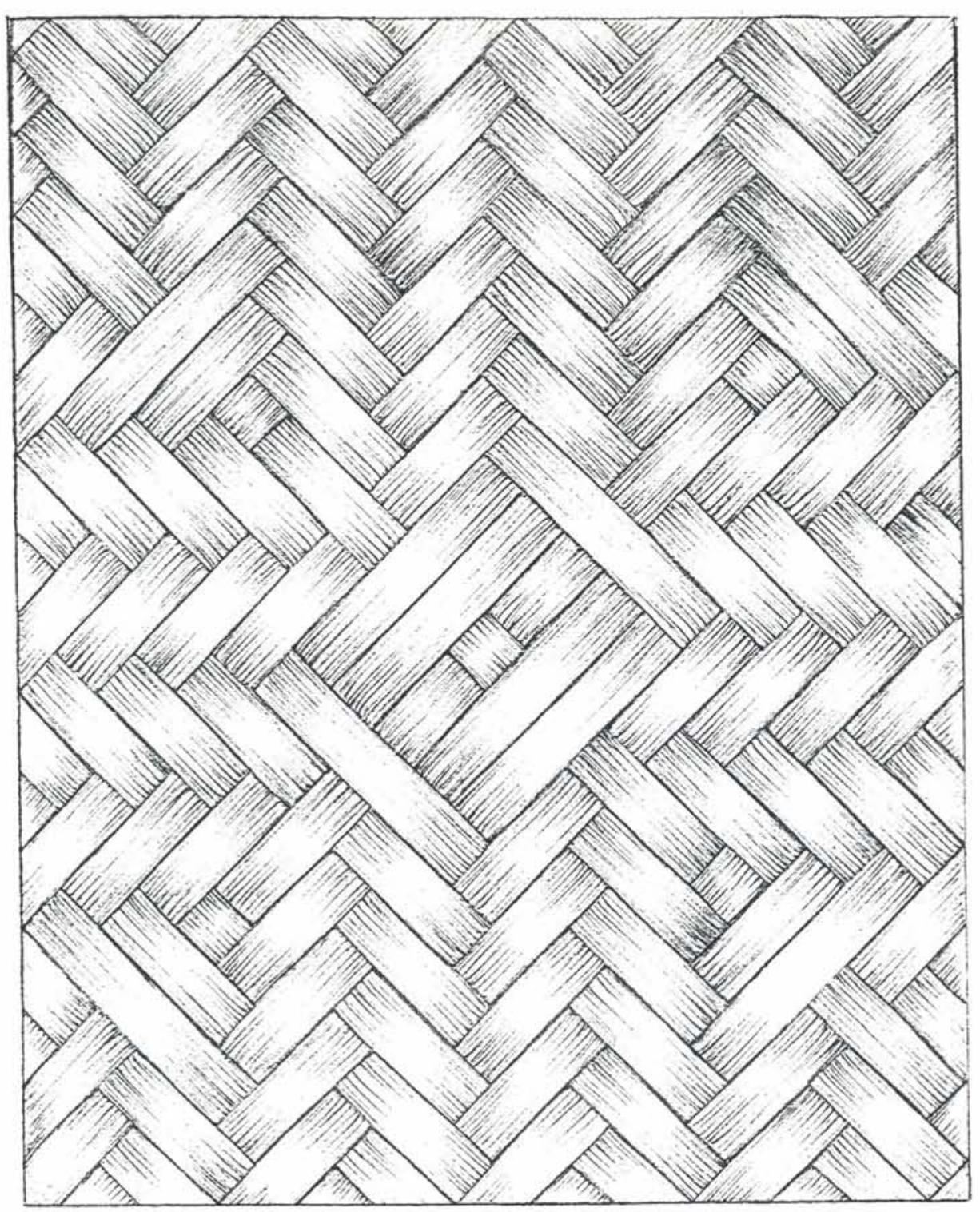

Figura 10 - Base de Kaipó: frente - R.G. n 11.334. 


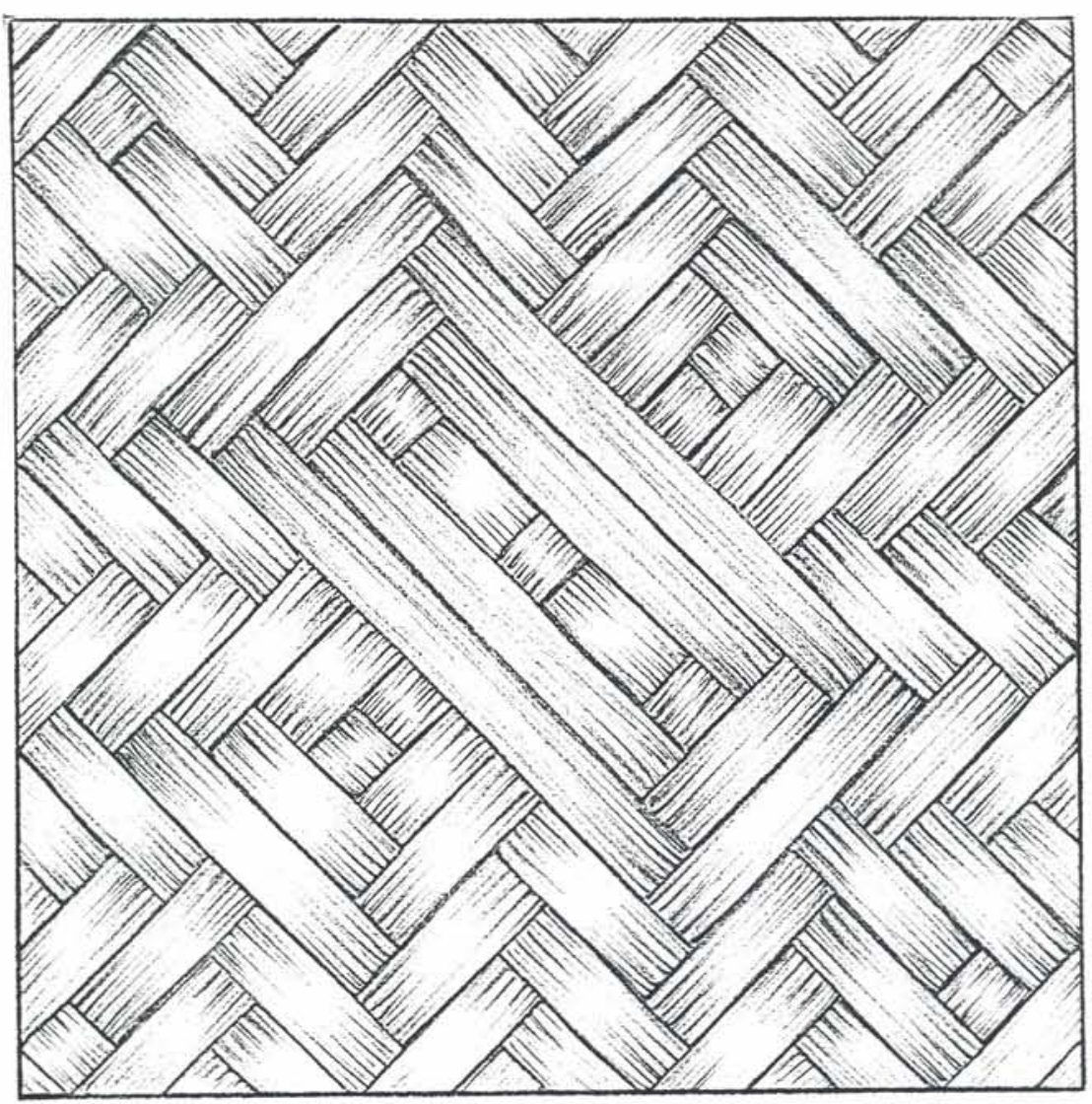

Figura 10a - Base de Kaipó: verso - R.G. n 11.334. 


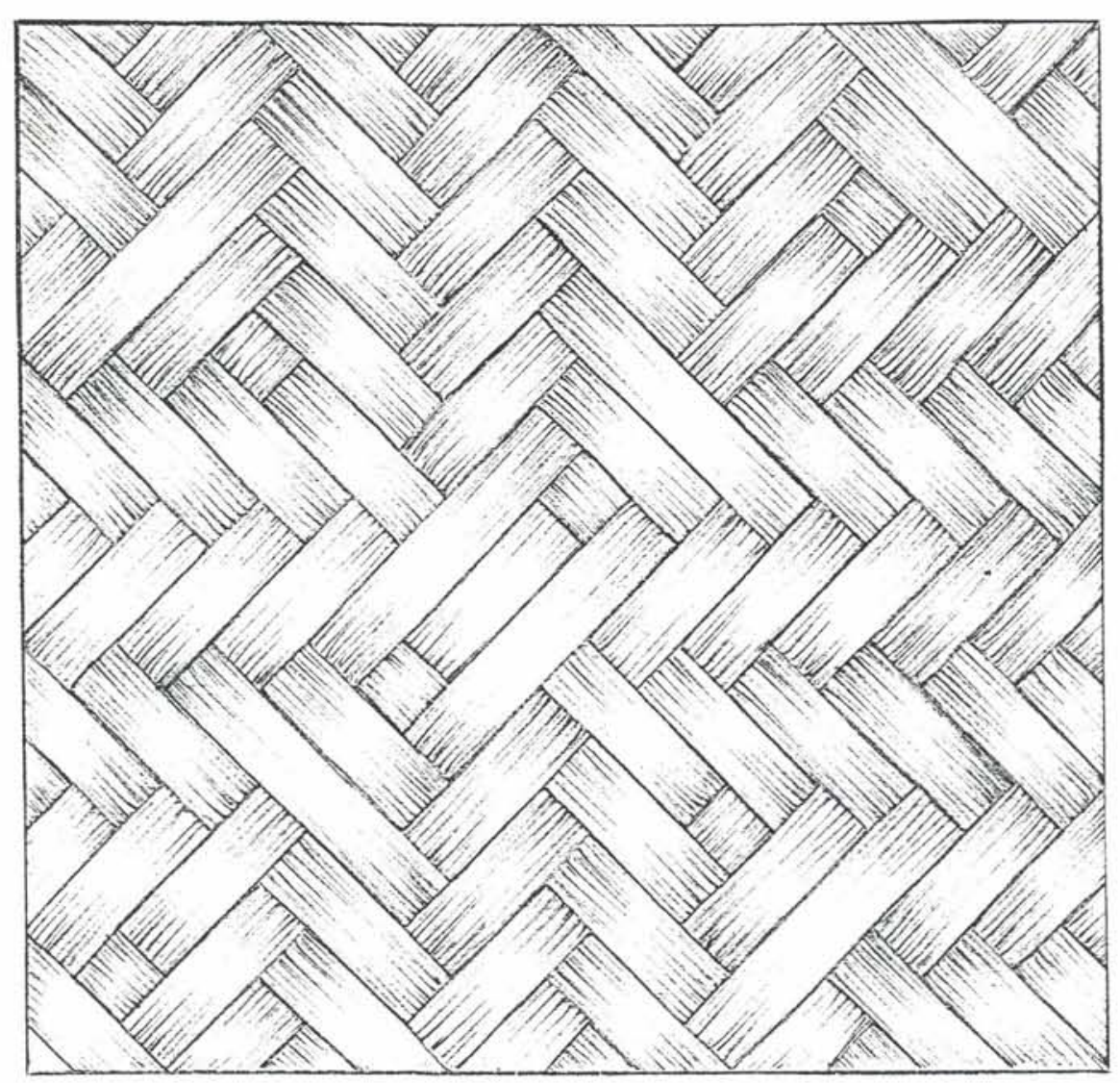

Figura 11 - Base de Kaipó: frente - R.G. nº 2764. 


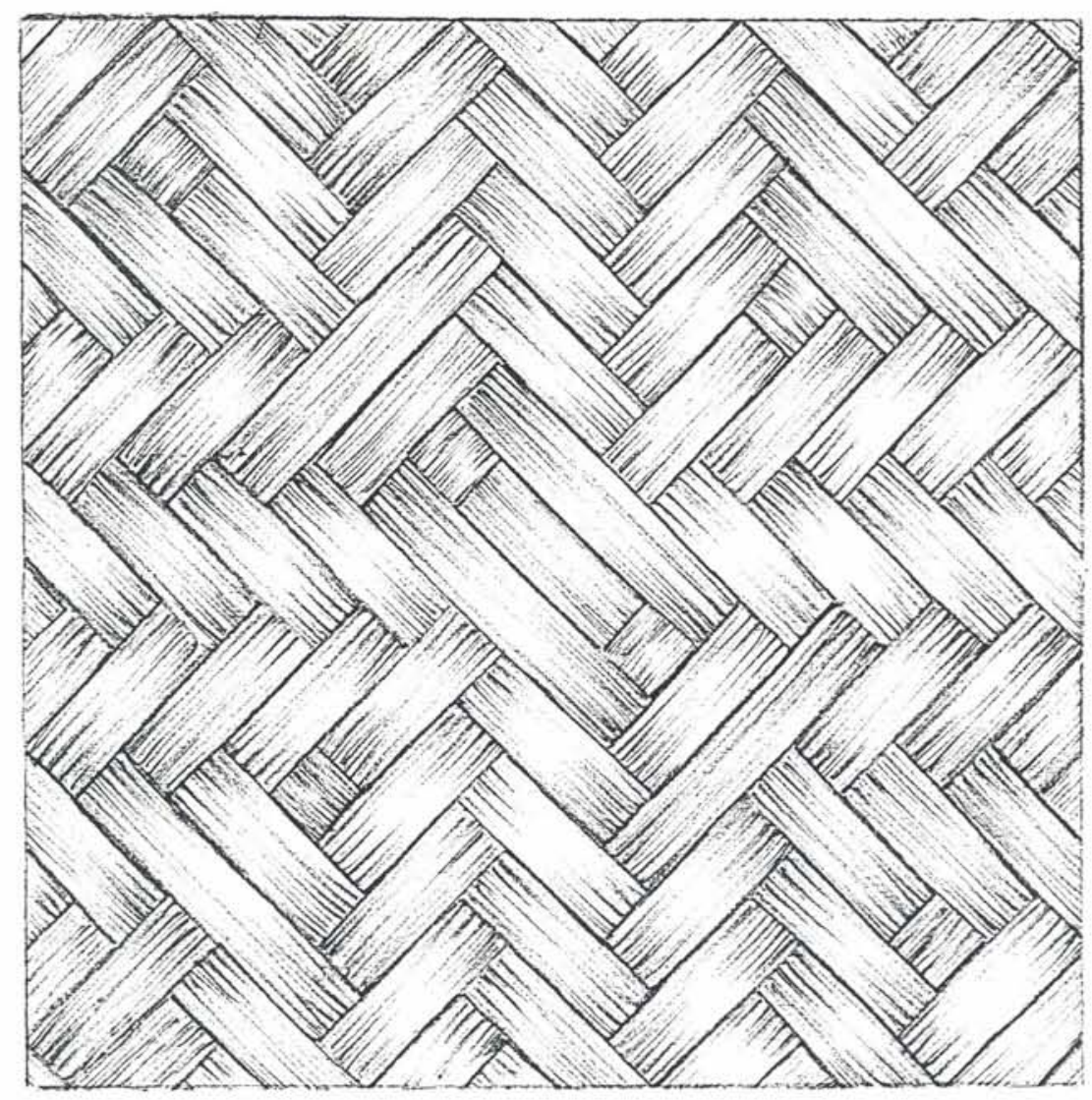

Figura 11a - Base de Kaipó: verso - R.G. nº 2764. 
Nas ilustrações das bases acima apresentadas podemos observar que a frente e o verso do trançado são diferentes. Confeccionando cada um desses tipos constatei que tecnicamente tanto um lado quanto o outro poderia ser a frente da base do Kaipó, mas, em minha amostra, ao contrário das bases primeiramente estudadas, nenhum verso foi usado como frente do traçado pelos Krahó.

As bases representadas nas figuras 7,8 e 9 são denominadas por Berta Ribeiro de base com início "olho"; essa denominação leva em conta o aspecto visual, porém mesmo visualmente as bases diferem entre si quanto ao número inicial das talas trançadas. Já as bases representadas nas figuras 10 e 11 são próximas em aparência da base "olho", mas são diferentes entre si quanto ao número e disposição das fasquias inicialmente trançadas.

Embora as configurações centrais - umbigos -dessas bases sejam diferentes, todas formam o mesmo tipo de trançado na superfície restante da base. Em especial, vemos nas linhas perpendiculares entre si a regularidade e intervalo usado pelo cesteiro, fazendo com que os bojos tecnicamente próprios dessas bases, por possuírem igual trançado, sejam os já representados nas figuras 5 e 6 . Ambos são possíveis de serem confeccionados com as bases acima, mas na amostra apenas os Kaipó de base representada na figura 7 correspondente a $12 \%$ - têm bojos feitos desses dois modos, os demais - $2 \%$ da amostragem, ou seja, um exemplar de cada tipo apresentam o bojo mais simples, ilustado na figura 5 . 
Uma vez que voltamos a esses bojos, vamos retomar a questão das direções do trançado em diagonal.

O bojo representado na figura 6 , como explicitamos anteriormente, apresenta o trançado em diagonal em duas direções: vertical e horizontal.

Confeccionando experimentalmente os trançados e em campo observando os Krahó tecendo os cestos e demais objetos de palha aprendi que a direção do traçado em diagonal depende da escolha de uma seqüência para se iniciar a alternância das fibras.

No trançado em diagonal podemos constatar que a verticalidade ou horizontalidade é expressão de um procedimento técnico que inverte a seqüência das fibras trançadas. Para se obter um trançado na direção vertical inicia-se o trabalho alternando-se as fibras segundo uma seqüência crescente e para se obter a direção horizontal usa-se uma seqüência decrescente.

As figuras 12 e 13 ilustram esses dois procedimentos, tomando como exemplo um trançado de intervalo três entre as fasquias. Como são os bojos apresentados até o momento. 


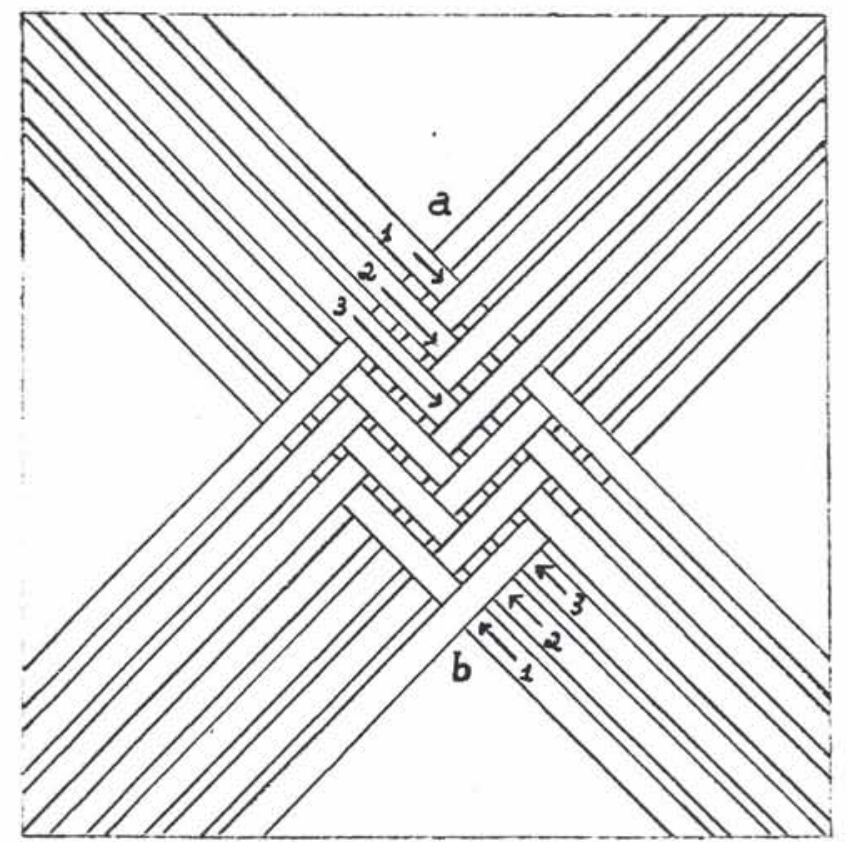

A e B - Pontos possíveis para se iniciar o trançado, pois este pode ser confeccionado de cima para baixo ou de baixo para cima.

Figura 12 - Seqüência crescente: trançado vertical.

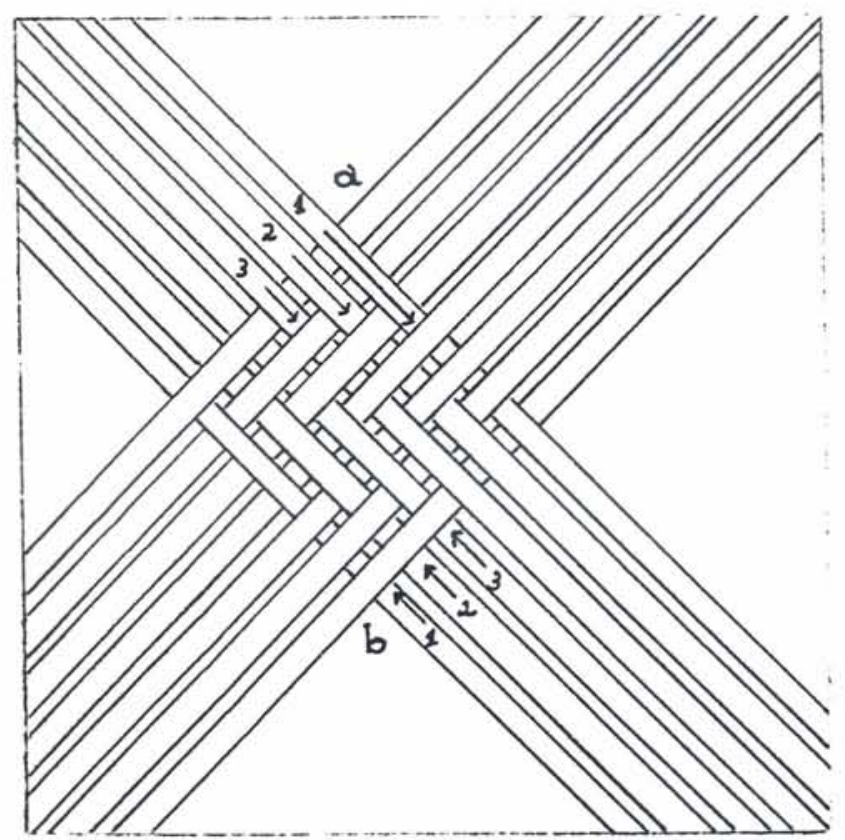

A e B - Pontos possíveis para se iniciar o trançado.

Figura 13 - Seqüência decrescente: trançado horizontal. 
Anteriormente, descrevendo o bojo representado na figura 6 afirmei que a parte de baixo tem um trançado vertical e a de cima horizontal. Qual o critério usado para essa classificação, uma vez que o bojo em si só nos informa sobre direções diferentes?

Usei como critério a leitura feita em campo pelos Krahó. É uma leitura visual baseada na técnica: as fibras são vistas como são trançadas, isto é, aos pares. Cada par forma uma unidade. O par horizontal chama-se Kokaikor e o vertical Kotxua. A figura 14 ilustra ambos os pares.

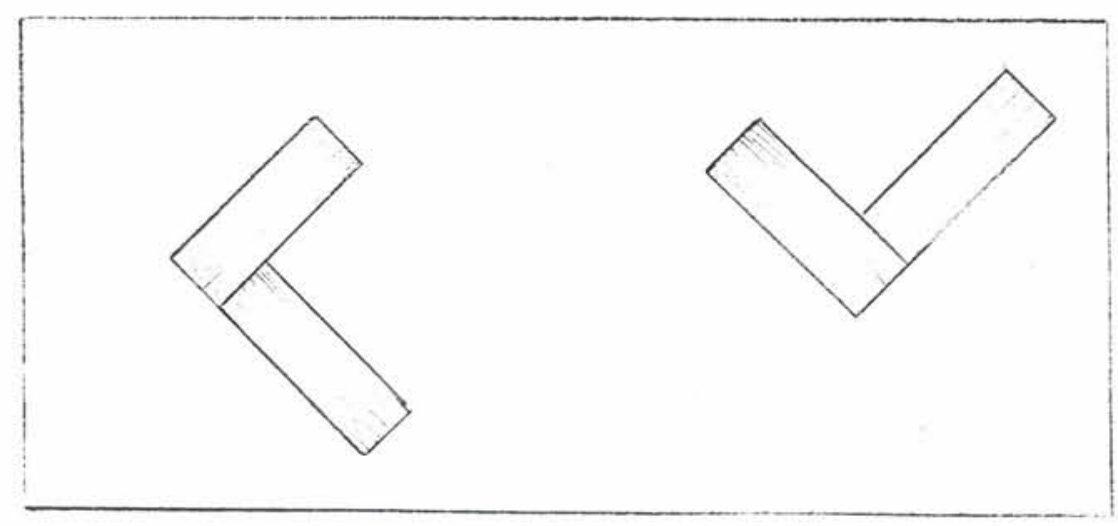

Figura 14 - Par kokaikor e Par kotxua.

Quaisquer trançados em diagonal são sempre Kokaikor ou Kotxua, segundo a direção do trançado seja, respectivamente, horizontal ou vertical.

Os termos Kokaikor ou Kotxua integram uma classificação mais ampla: Kokaikor é Katamye e Kotxua é Wakmeye. 
Katamye e Wakmeye são metades, nas quais os Krahó ordenam pessoas, segundo o nome pessoal, animais, astros, plantas, isto é, provavelmente, todo o universo. Por exemplo: são Katamye: a estação chuvosa, a água, a lua, a noite, a cor preta, a sucuriju, o gavião, etc. Por sua vez, são Wakmeye: a estação seca, o sol, o dia, a cor vermelha, o milho, o periquito, etc.

Os elementos ordenados em cada uma dessas metades relacionam-se entre si por semelhança e os elementos ordenados em metades diferentes relacionam-se enre si por contraste. Se pertencer a uma dessas metades é um dado fixo, o contraste entre elementos Katamye e Wakmeye não é único, isto é, cada elemento de uma metade contrasta-se com todos os outros elementos da outra metade, dependendo do contexto das associações.

Em campo, os Krahó ao tecerem para mim o bojo de um Kaipó me explicaram que o trançado na direção horizontal Kokaikor - é Katamye, ele "vai e volta como as águas" e que o trançado vertical - Kotxua - é Wakmeye, ele "sobe e desce como o milho".

É o trançado em diagonal, isto é, o buriti trançado, Krou-ko, que é classificado em Ktoxua e Kokaikor, integrando-se de modo dual no universo Krahó.

O cesto Kaipó é composto de ambos os pares. Ele é um todo. 
Visualmente o par de fasquias Kotxua tem a forma V e o par Kokaikor a forma <. Esses são sinais usados também pelas pessoas no corpo - ante-braço, seio ou face - identificando a metade a que pertencem. Os Krahó fazem um paralelo entre a pele humana e a cestaria, pois, de modo coerente, o cesto Kaipó não identifica a sua proprietária segundo esse sistema de metades e a cestaria como a pele humana segundo CUNHA (1978) não tem cor, ambas são Hakati.

Os diferentes padrões do trançado em diagonal são obtidos não só invertendo-se a direção do trançado, mas também através do intervalo usado pelo cesteiro no entrecruzamento das fasquias.

Há inúmeros intervalos possíveis, mas não infinitos: qualquer quer seja o intervalo adotado pelo cesteiro, este deve garantir a formação do tecido sem erros. Para a formação do tecido é condição o cruzamento das fibras aos pares: em cada novo momento do trabalho não se pode ter nem fibras em falta, nem em excesso, o que constituiria, respectivamente, um buraco ou uma superposição de fibras no trançado, isto é, um erro no tecido.

Entre os Krahó, para a confecção dos Kaipó, o intervalo mais usado é aquele em que o par de fibras cruza, ora por cima, ora por baixo, sempre três fasquias. Todos os bojos acima ilustrados correspondem a este padrão. 
Há, porém, outros intervalos menos usados e que apresentam maior dificuldade em sua confecção, quer por terem intervalos maiores que três, quer por terem intervalos irregulares, isto é, intervalos onde o cesteiro cruza em cada vez quantidades diferentes de talas. Assim como os inícios da base, esses padrões de trançado irregulares são chamados de Iroc pelos Krahó.

As figuras 15 e 15 a representam respectivamente a frente e o verso da base de um Kaipó confeccionado com intervalo quatro entre as talas. Constatamos esse intervalo, a nível visual, observando o trançado formador das linhas perpendiculares entre si a partir do centro da base. Uma vez que base e bojo são contínuas, o bojo desse tipo de Kaipó - correspondente a 4\% de minha amostra foi feito totalmente com o mesmo intervalo da base, como ilustra a figura $15 \mathrm{~b}$.

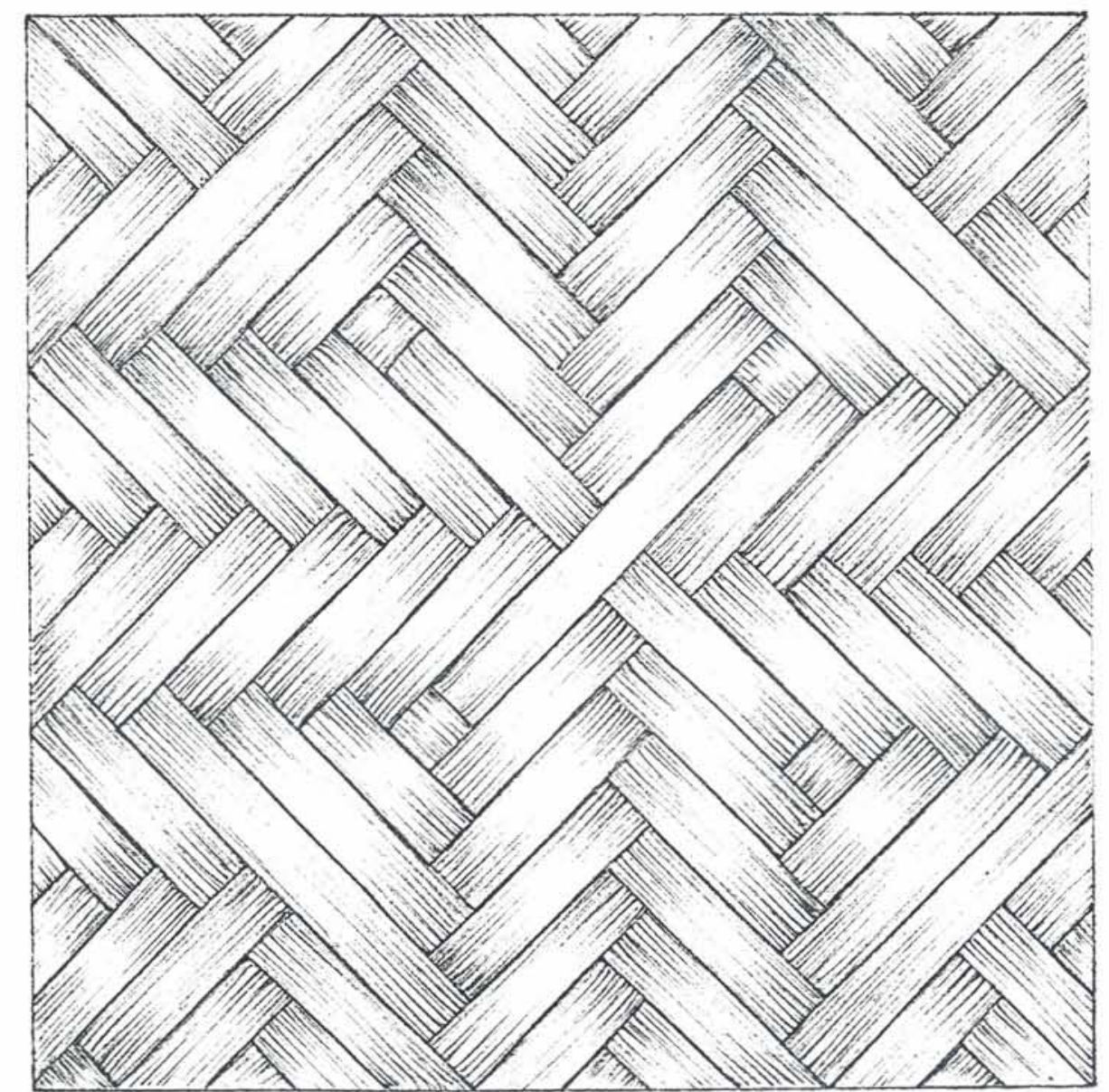

Figura 15 - Base do cesto: frente - R.G. n 2743. 


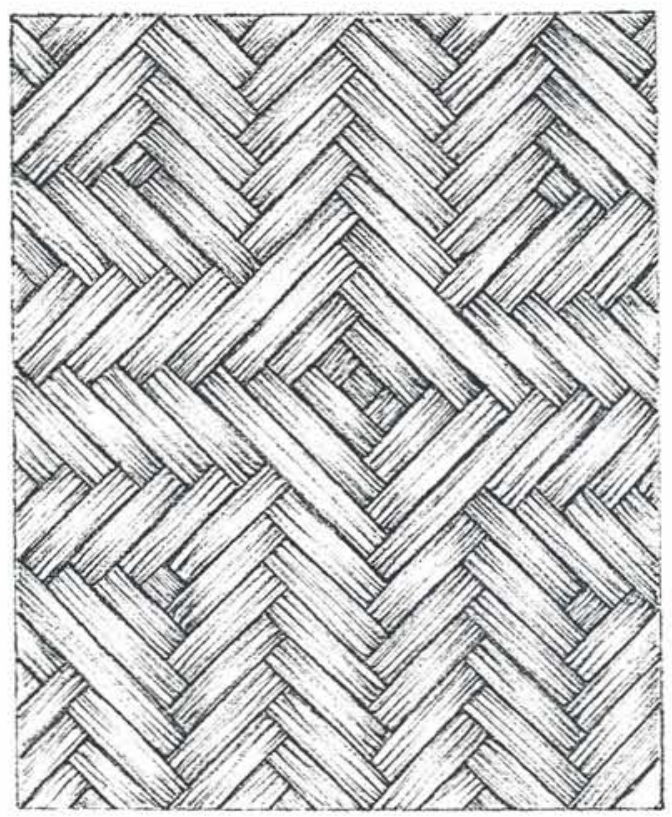

Figura 15a - Base do cesto: verso - R.G. n 2743. 


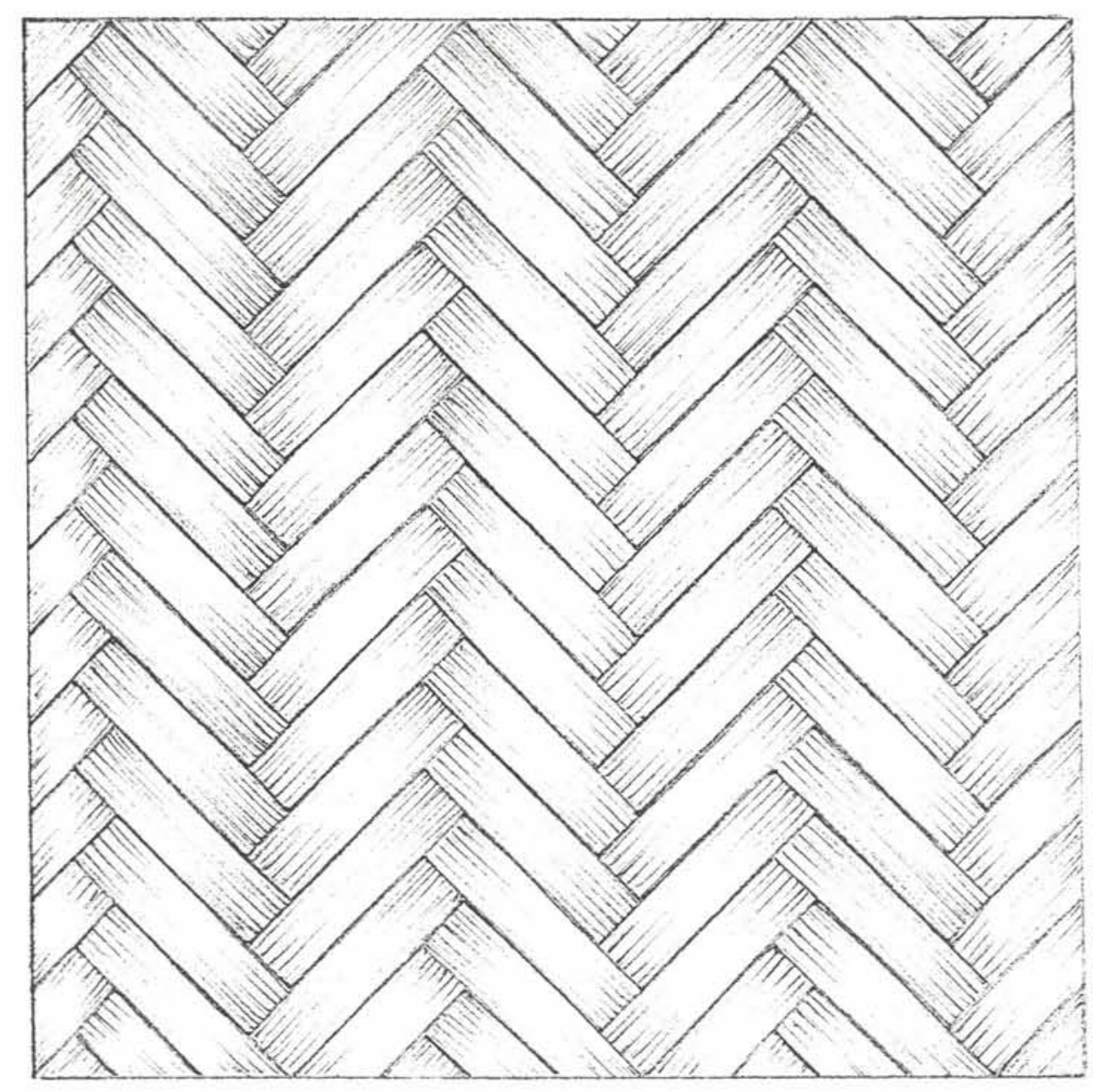

Figura 15b - Bojo do cesto - R.G. nº 2743. 
As figuras 16 e 16 a representam a frente e o verso de um outro tipo de base. Entre todas as bases estudadas em minha amostra, este tipo é o mais dificil de ser confeccionado porque se inicia o trabalho com sete talas soltas, o que é um número grande para ser devidamente entrecruzado até se obter um tecido que por si só se firme.

Embora a configuração central - umbigo - desta base seja diferente da ilustrada anteriormente, foi usado para sua confecção o mesmo intervalo quatro entre as talas.

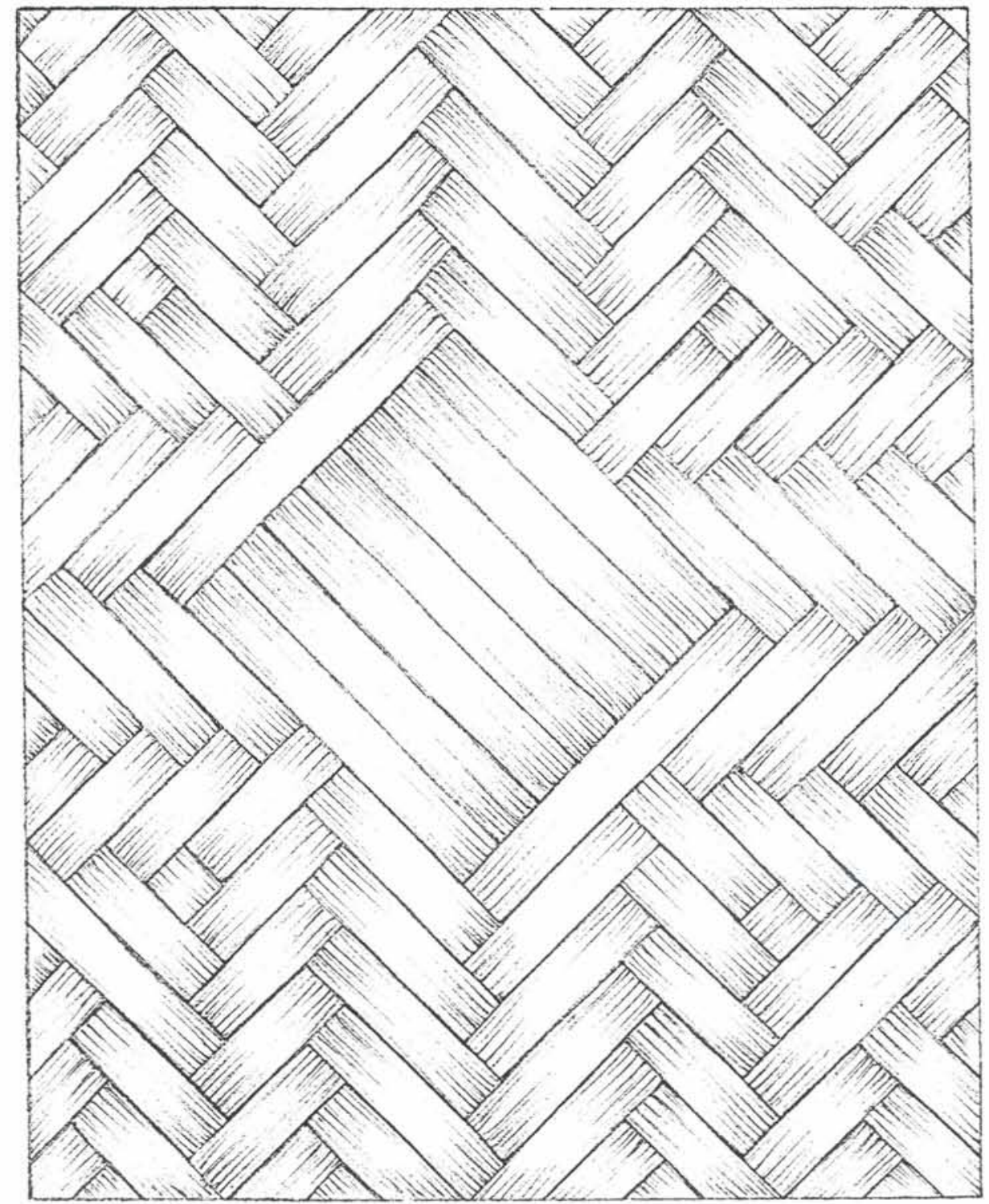

Figura 16 - Base do cesto: frente - R.G. n 10285. 


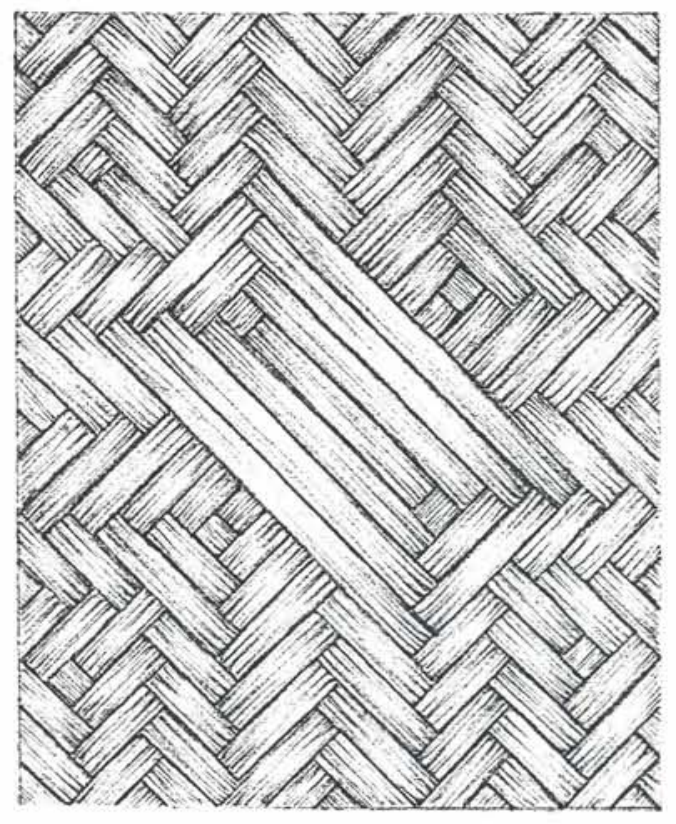

Figura 16a - Base do cesto: verso - R.G. nº 10285. 
A figura $16 \mathrm{~b}$ ilustra o bojo deste exemplar. O cesteiro usou para a confeção deste bojo o intervalo três entre as fasquias, mas como decorrência do tipo de base escolhida e em continuidade a esta, formou-se em cada um dos lados do bojo uma linha mediana com intervalo maior, igual ao da base.

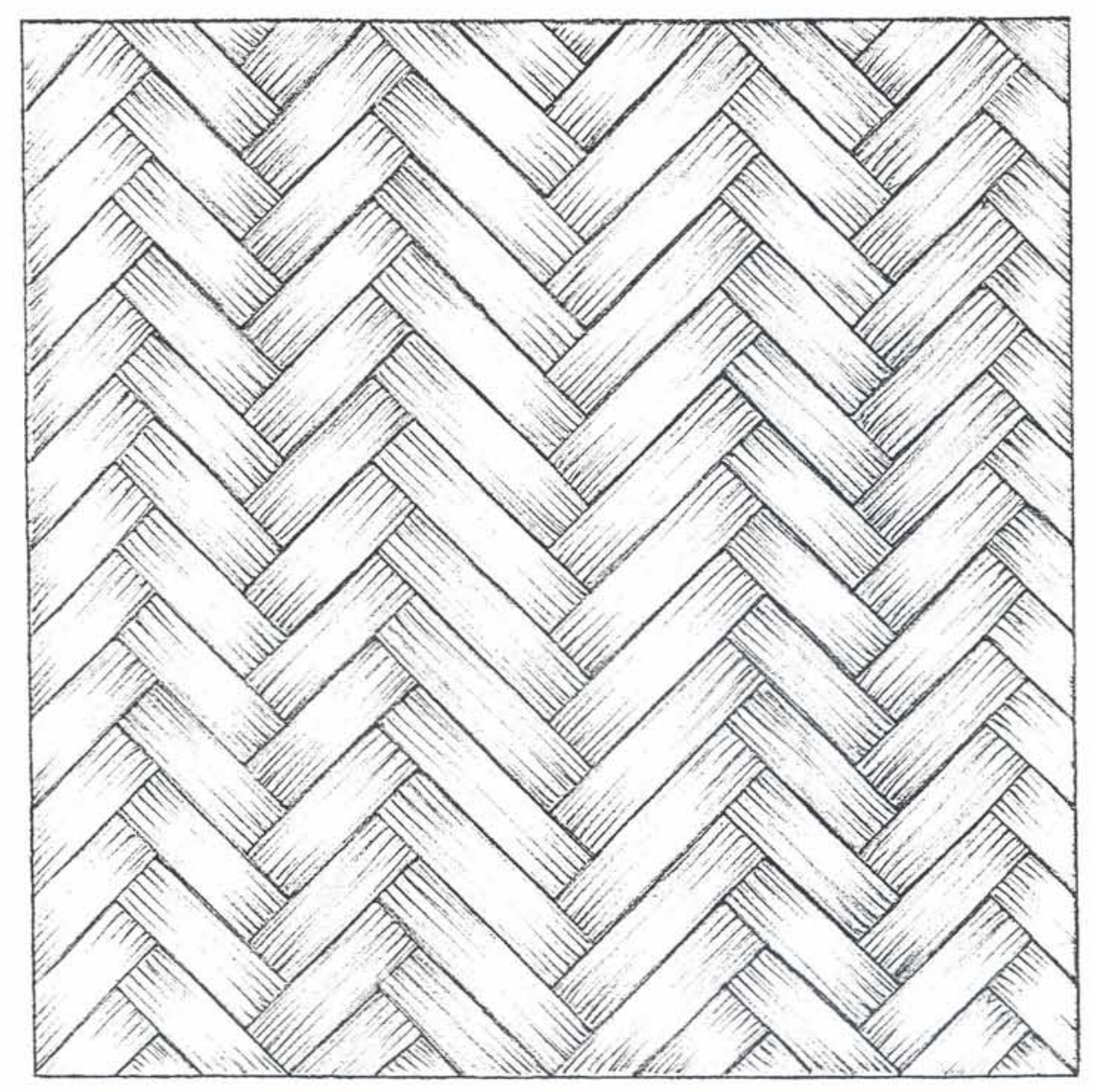

Figura 16b - Bojo do cesto - R.G. nº 10.285. 
As figuras 17 e 17 a são respectivamente a frente e o verso da base de um Kaipó com configuração central em cruz.

Aqui, o número de talas usado originou linhas perpendiculares entre si formadas por um par de talas cruzadas com intervalos diferentes.

A base como um todo, devido à diversidade de intervalos usados exige um bom domínio da técnica por parte do cesteiro.

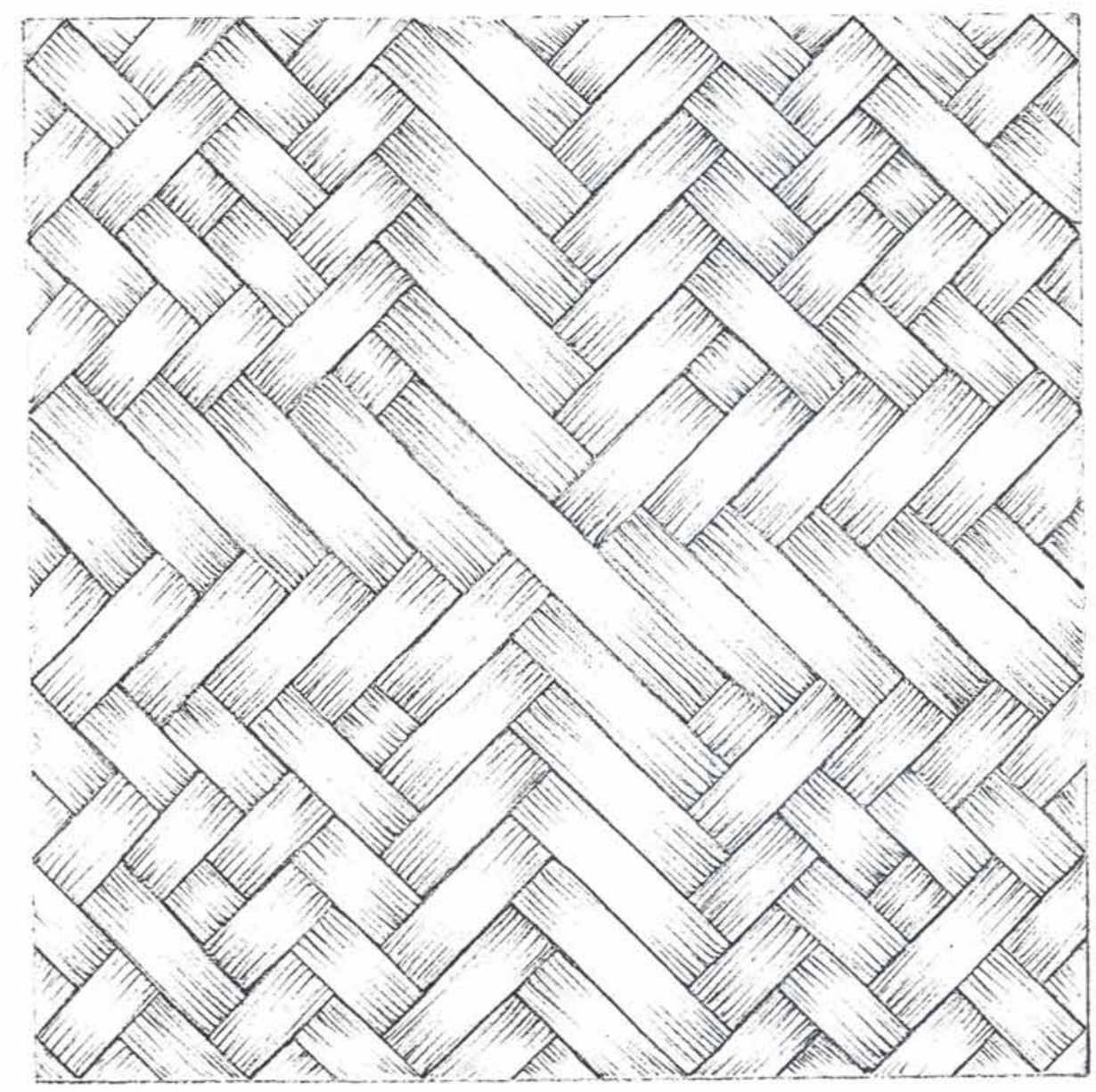

Figura 17 - Base de Kaipó: frente - R.G. n 9.111. 


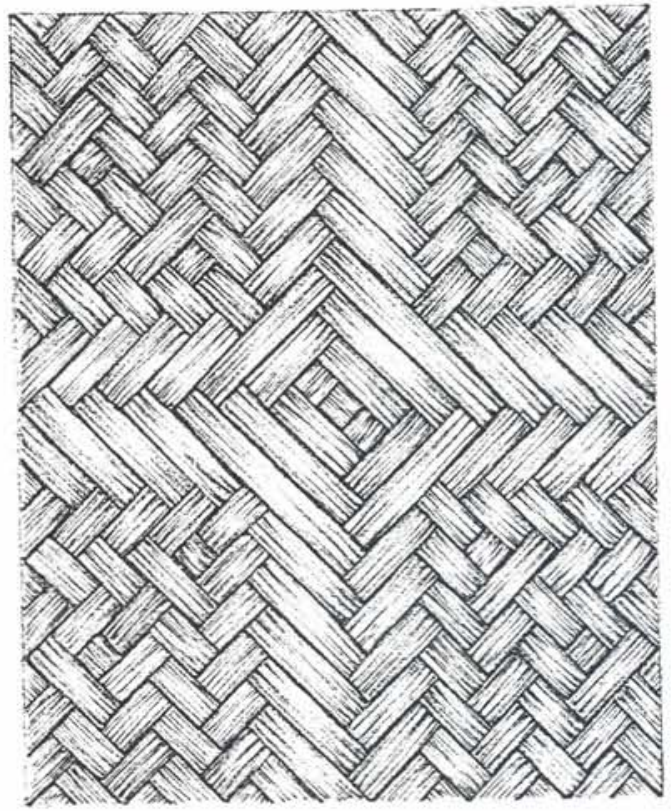

Figura 17a - Base de Kaipó: verso - R.G. n 9.111. 
Com a figura 17 b ilustro o bojo deste Kaipó - exemplar único em minha amostra. Neste bojo base escolhida determinou em cada um dos lados uma linha mediana com um trançado de intervalos diferentes entre si, iguais aos da base. No restante do trabalho, o cesteiro optou por um intervalo dois entre as fasquias. A irregularidade inicial refletiu-se na hora de inverter a direção do trançado, formando dois tipos de Aican ietxo. Notamos que mesmo o trançado de direção horizontal foi mesclado com uma listra de intervalo menor entre as fasquias. Neste bojo o cesteiro joga tanto com necessidades técnicas como com opções individuais, o que revela sua maestria no domínio técnico da cestaria.

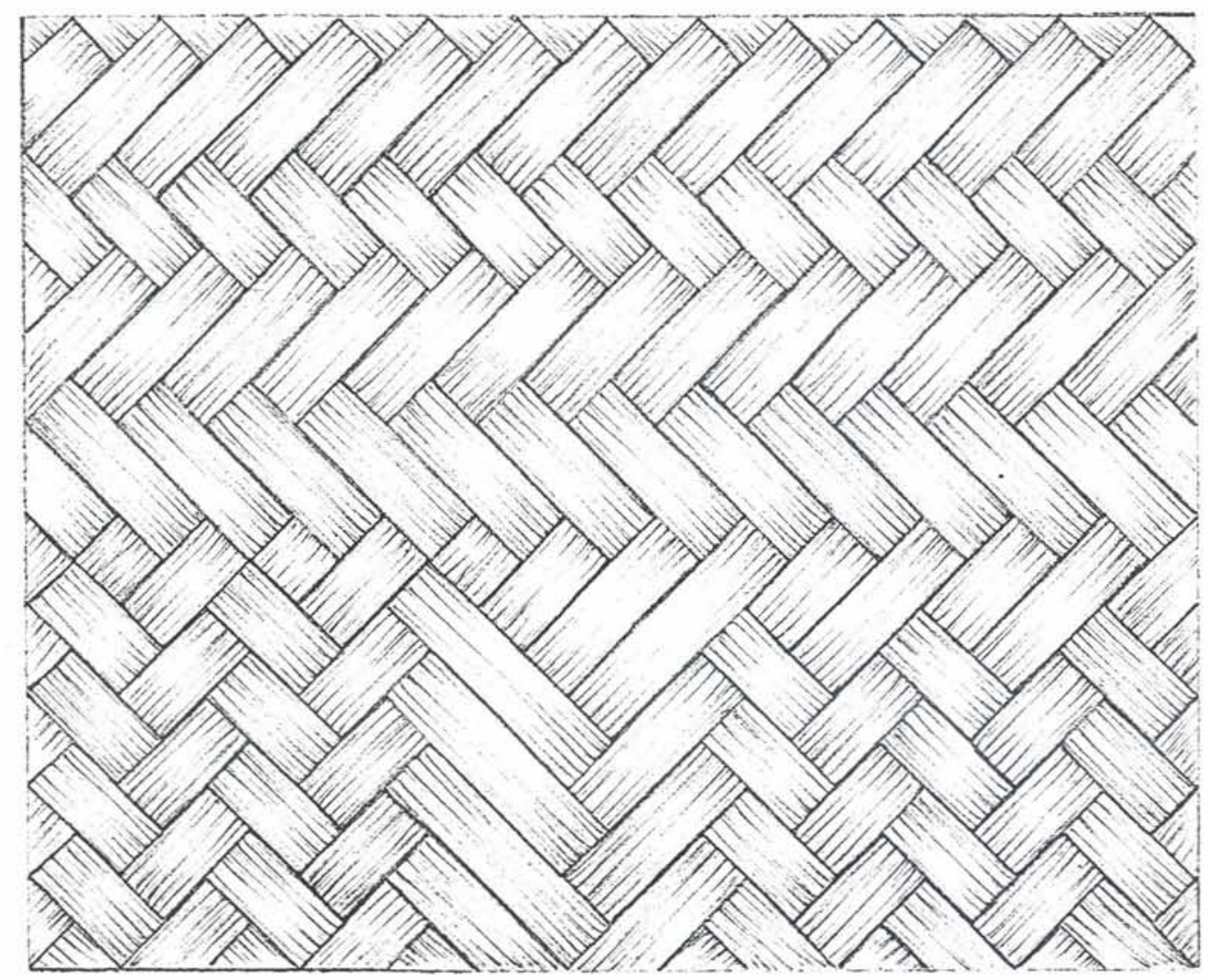

Figura 17b - Bojo do Kaipó - R.G. nº 9.111. 
Mostro com as ilustrações 18, 18a e 18b, respectivamente a frente, o verso e o bojo de um Kaipó que nos permite mais uma vez falar em necessidades técnicos e em escolhas deliberadas.

Notamos que a configuração central desta base é em cruz e que seu verso é em diamante. Como nas figuras 1 e 2 , porém em menor proporção - há apenas dois exemplares em minha amostra este tipo de começo também é usado indistintamente como frente ou como verso do Kaipó .

Todas as bases de Kaipó até o momento apresentadas possuem frente e verso diferentes. Confeccionando experimentalmente todas essas bases aprendi que do ponto de vista técnico todos os versos são viáveis, isto é, pode-se confeccionar um cesto usando indistintamente quaisquer das frentes ou versos ilustrados. Desse leque de possibilidades, os krahó usam apenas esses dois tipos, fazendo uma escolha que se baseia em critérios próprios e culturais. 


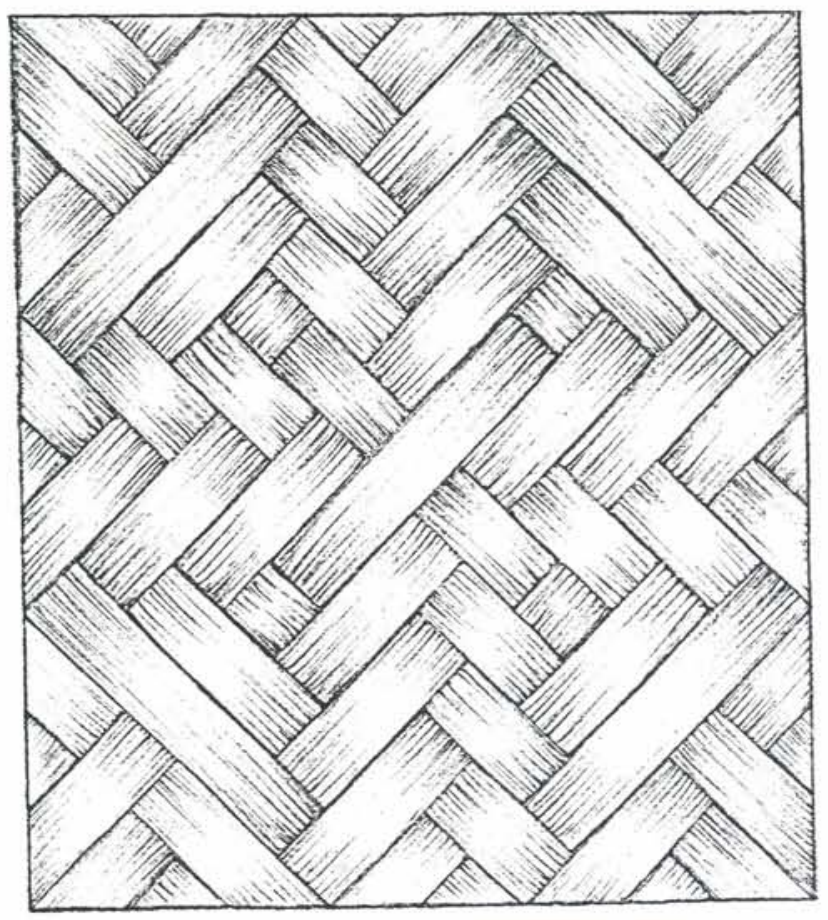

Figura 18 - Base de Kaipó: frente - R.G. nº 2739. 


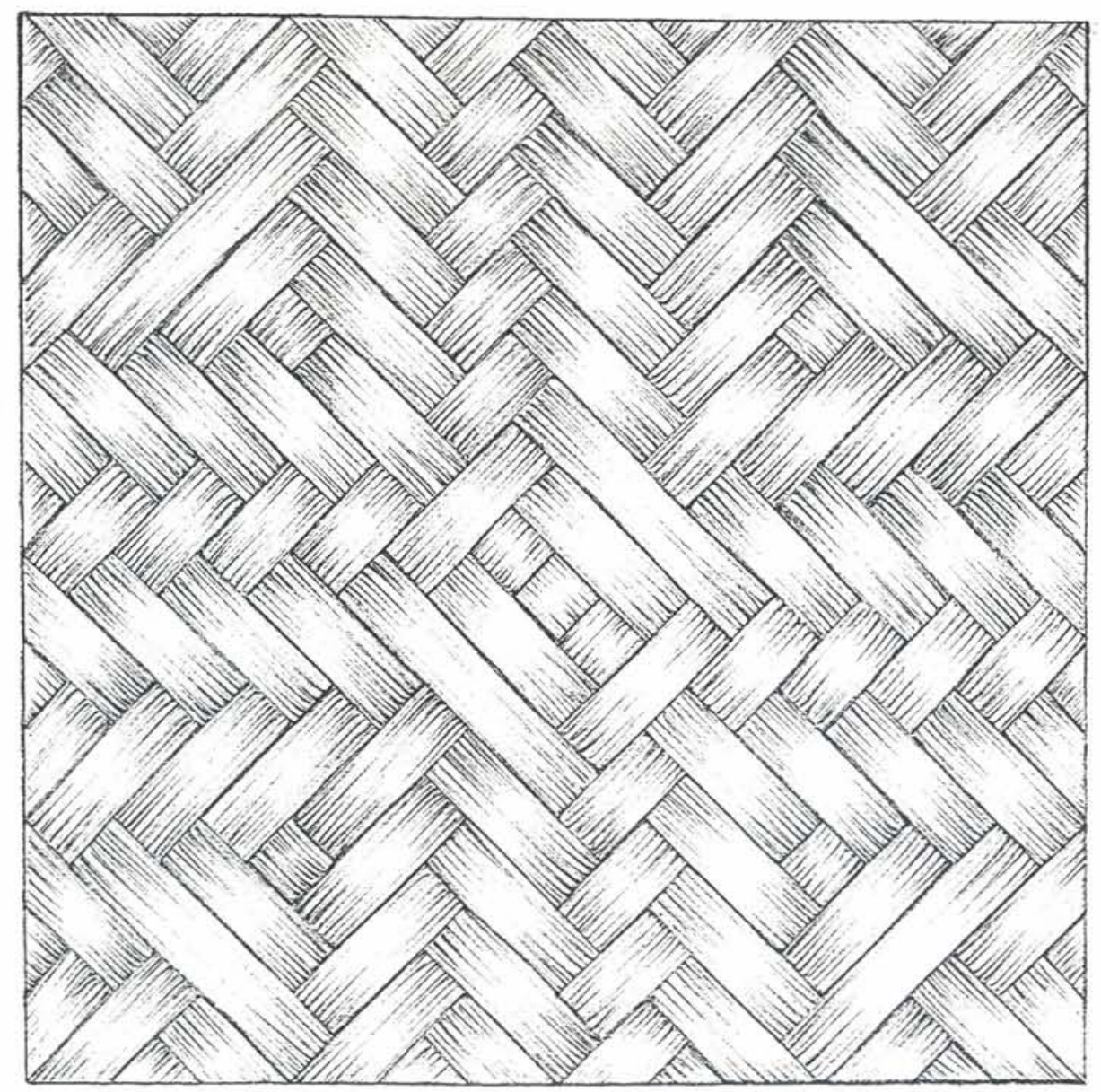

Figura 18a - Base de Kaipó: verso - R.G. n² 2739. 
Este bojo é decorrente de uma necessidade técnica: uma vez escolhida a base da figura 18 pelo cesteiro, necessariamente o bojo apresentaria de cada lado a faixa central com os mesmos intervalos usados na base.

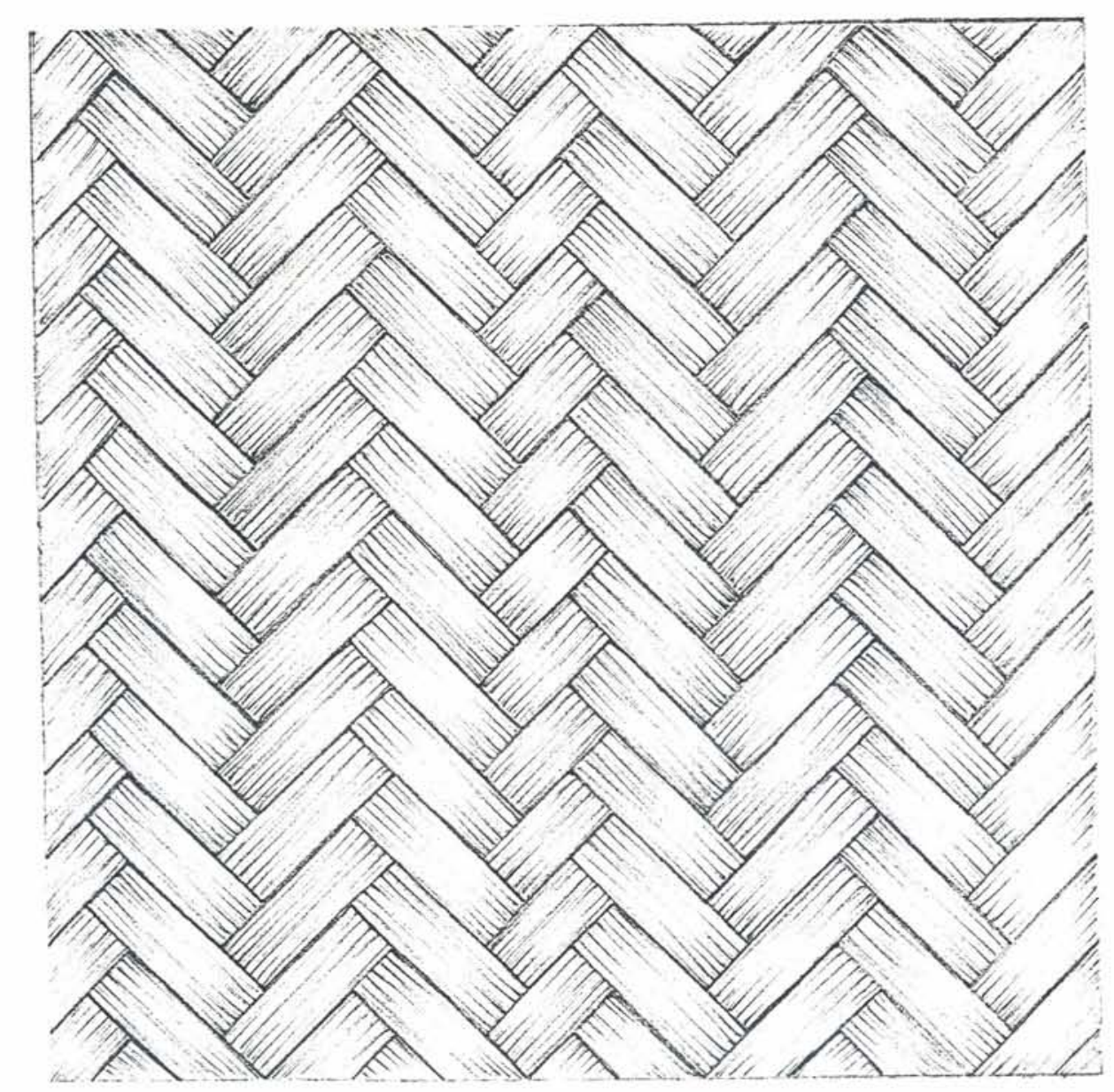

Figura 18b - Bojo de Kaipó - R.G. nº 2739. 
Na seqüência mostro um grupo de Kaipó, cujos padrões da base e do bojo diferem muito dos já estudados, mas que são possuidores de uma série de características em comum, das quais destacaria a liberdade de criação do cesteiro.

A figura 19 ilustra a base de um desses Kaipó. Este tipo presente em minha amostra na freqüência de $12 \%$ - é comum entre outros grupos indígenas, como por exemplo, entre os Canela-Ramkokameka que como os Krahó pertencem a família linguística Jê-timbira, e entre os Guajajara, índios de língua Tupi, habitantes do Estado do Maranhão, na confecção de um cesto formalmente igual ao Kaipó, denominado Pacuti.

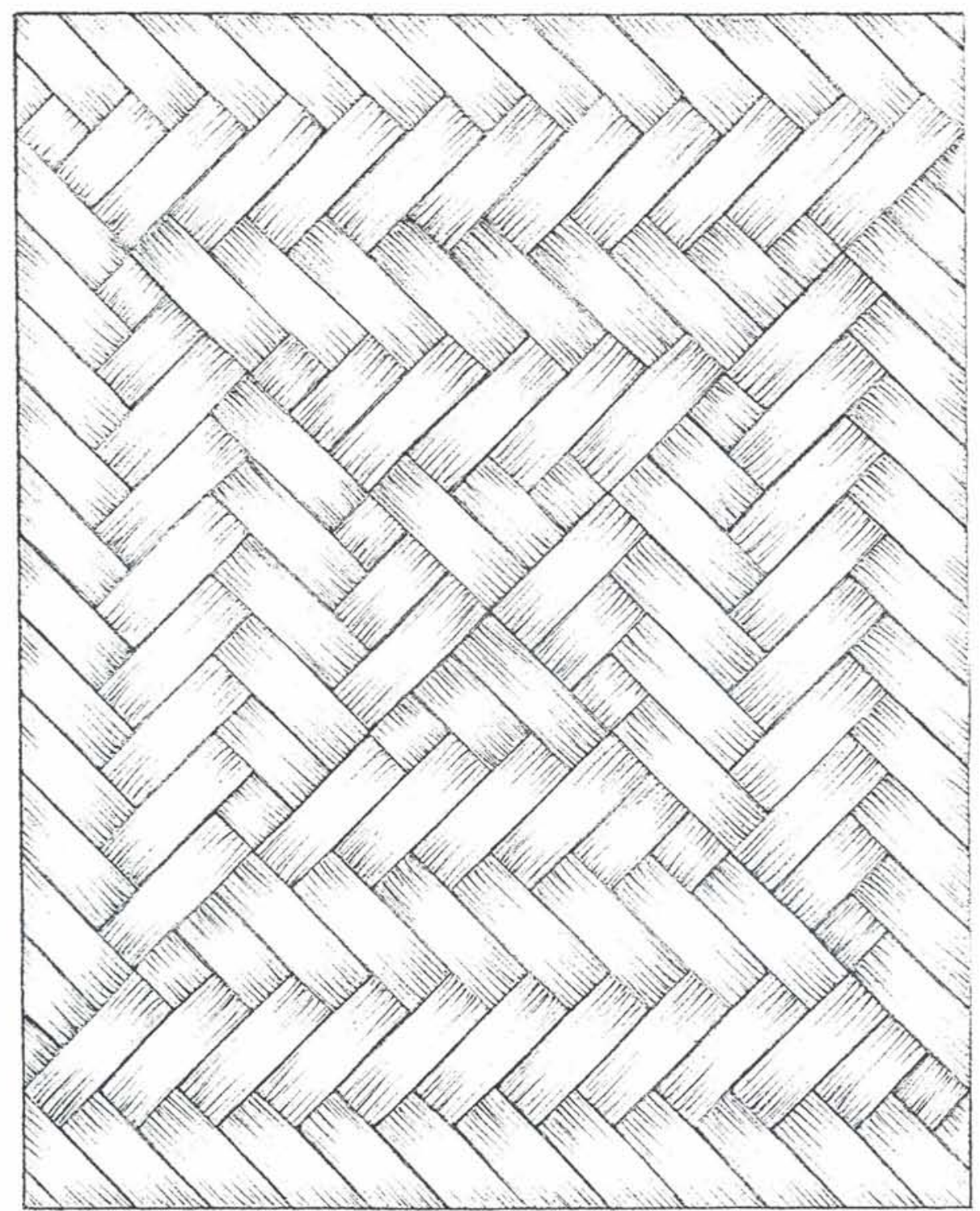

Figura 19 - Base de Kaipó - R.G. 35. 
Nestes tipos de Kaipó a disposição inicial das fasquias para a confecção da base determina no bojo o trançado em diagonal sempre na direção horizontal. Embora a direção seja única horizontal - encontramos variedades, mostradas nas figuras 19a, 19b, $19 \mathrm{c}, 19 \mathrm{~d}$ e $19 \mathrm{e}$.

O bojo ilustrado na figura 19a exemplica o trançado em diagonal horizontal e é o padrão mais simples e mais comum para a base apresentada acima.

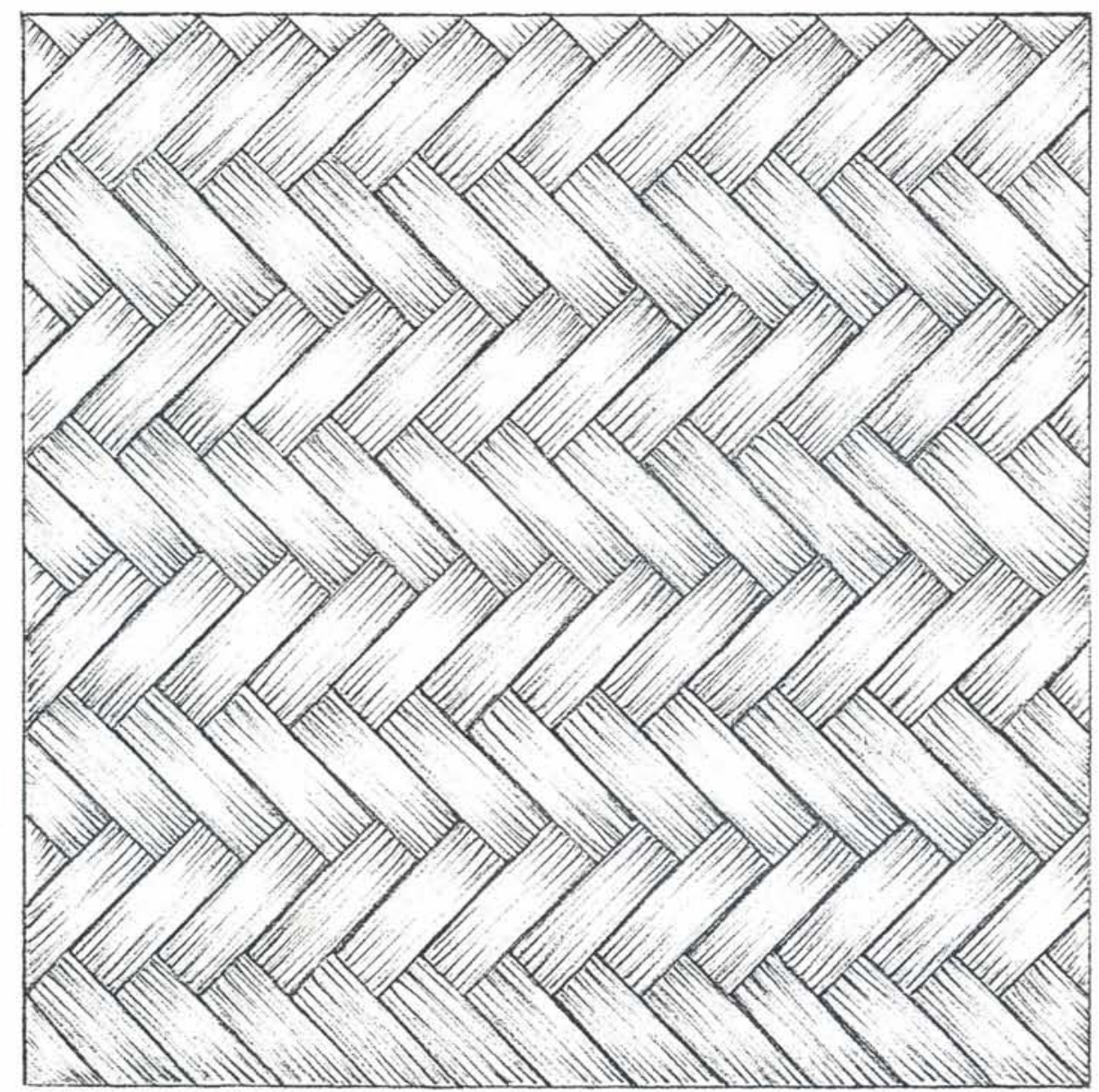

Figura 19a - Bojo de Kaipó - R.G. n 35. 
A figura $19 \mathrm{~b}$ mostra um bojo que aparentemente é igual ao anterior, mas se atentarmos para os intervalos usados em sua confecção notaremos intervalos maiores e menores formando listras. A sutileza dessas listras nos remete à acuidade visual Krahó que desenha e vê em um jogo monocromático de luz e sombra.

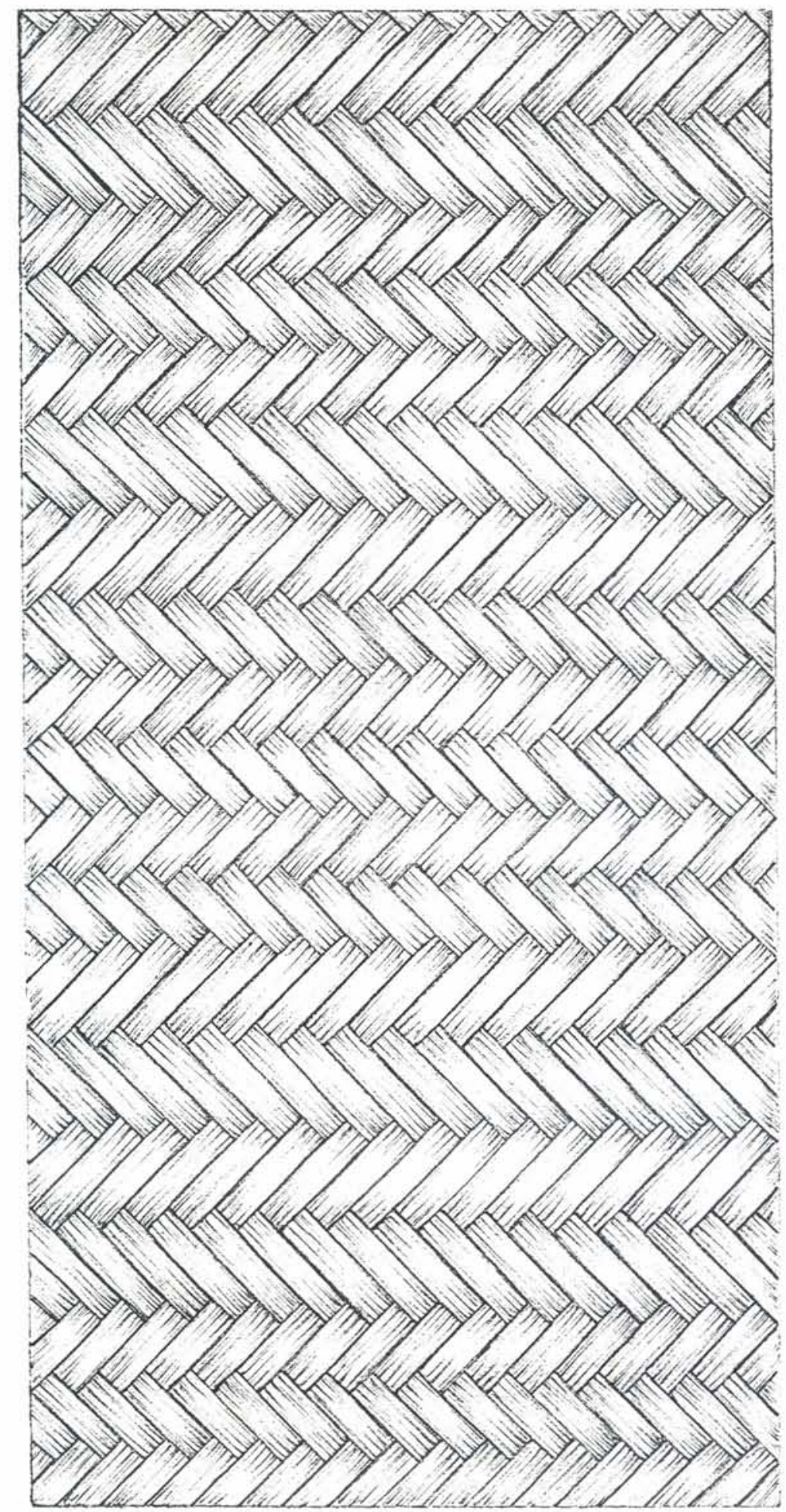

Figura 19b - Bojo de Kaipó - R.G. n 9.114. 
Na figura $19 \mathrm{c}$ o cesteiro em dois momentos inverteu a direção do trançado, formando uma faixa central no bojo. $\mathrm{O}$ trançado horizontal em baixo é decorrente da base, o de cima, como foi explicado anteriormente, é necessário para a construção do remate; a faixa central, no entanto, é uma opção livre do cesteiro.

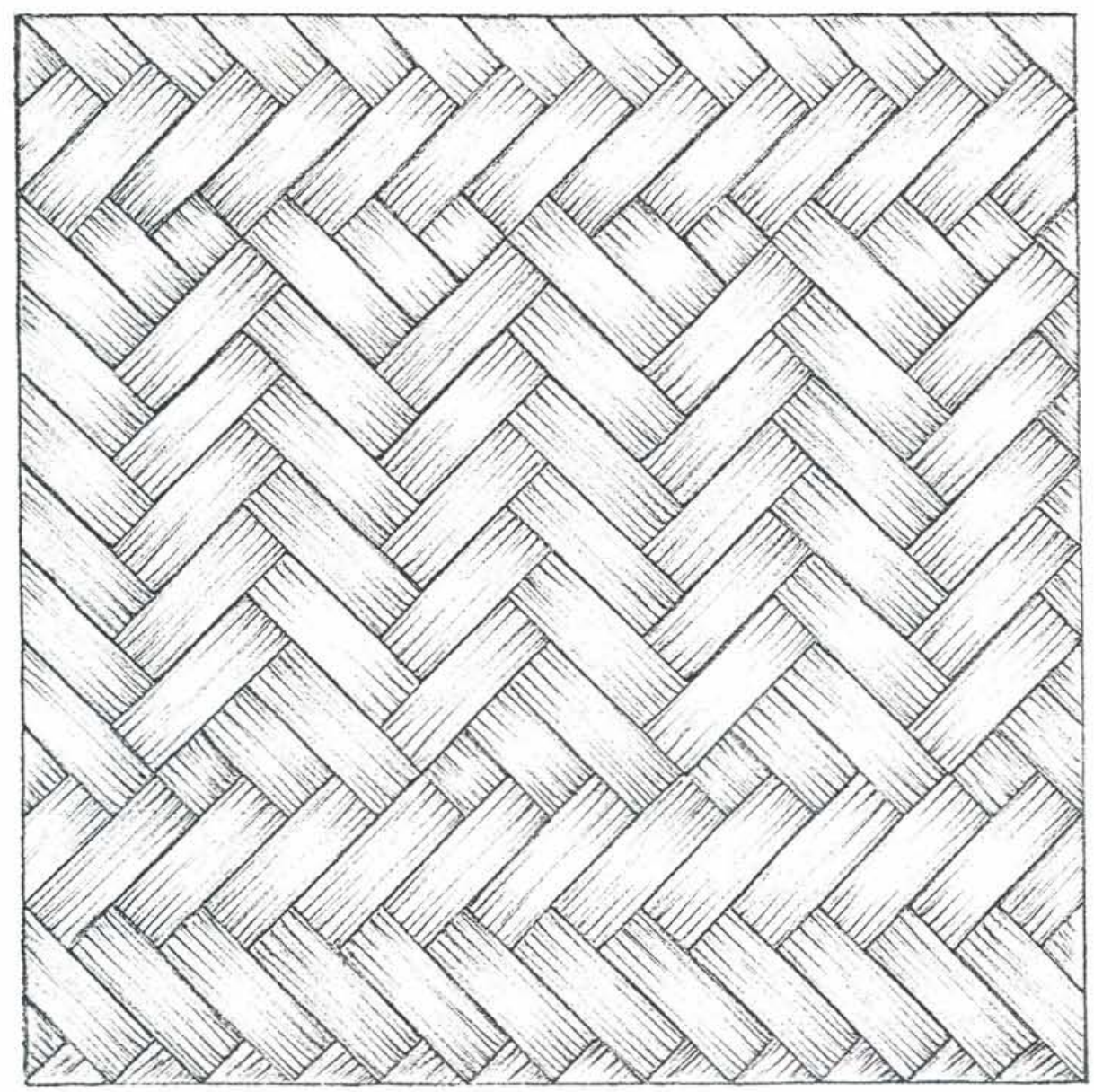

Figura 19c - Bojo de Kaipó - R.G. n² 29. 
As figuras $19 \mathrm{~d}$ e $19 \mathrm{e}$ são visualmente diferentes e tecnicamente complementares entre si, pois são frente e verso de um mesmo trançado.

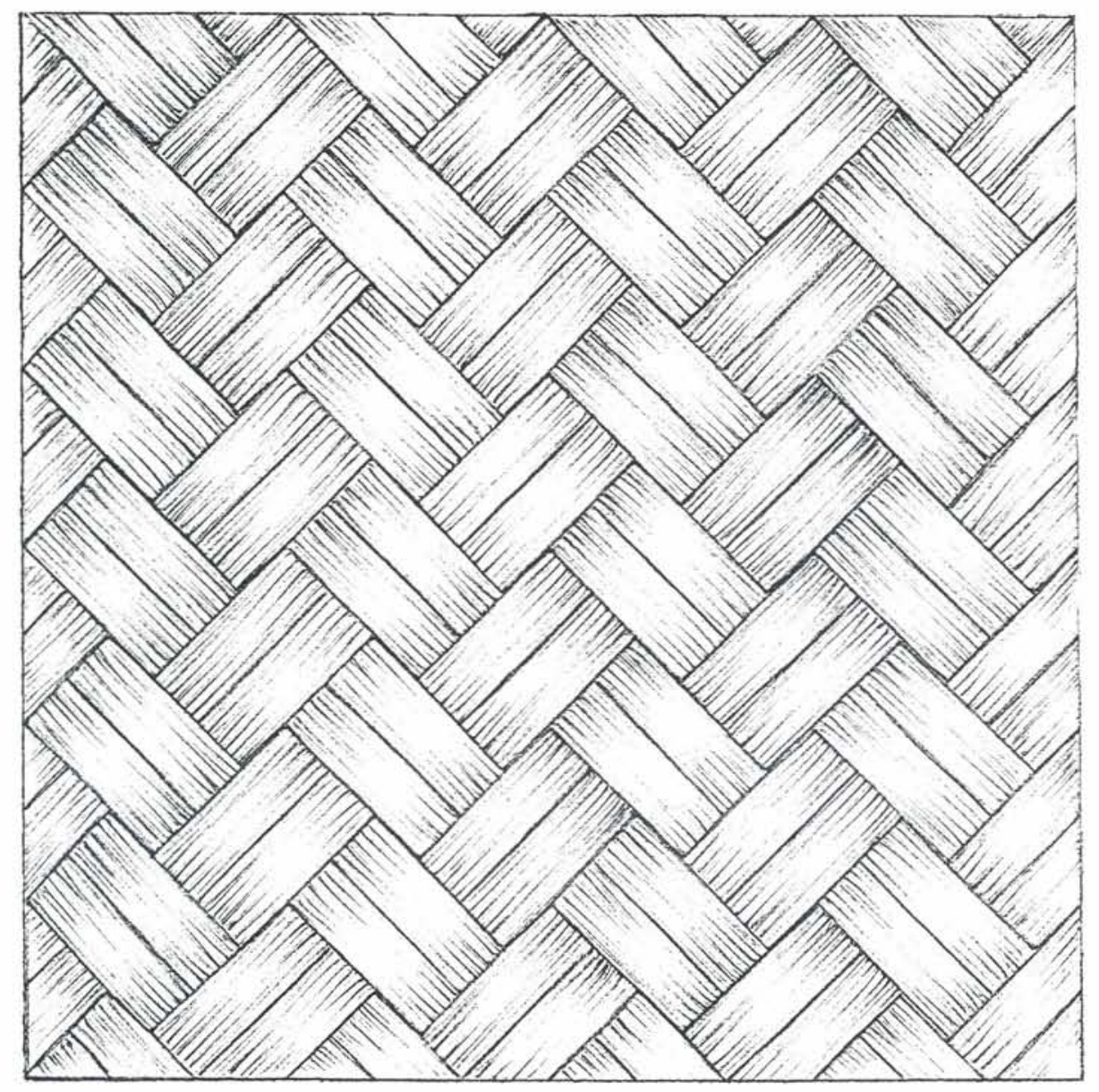

Figura 19d - Bojo de Kaipó: frente - R.G. nº 9.116. 
O cesteiro obteve ambos os tipos de bojo usando intervalos irregulares entre as talas a serem cruzadas. Os padrões de trançado assim obtidos são também enfeites - iroc -, segundo os Krahó.

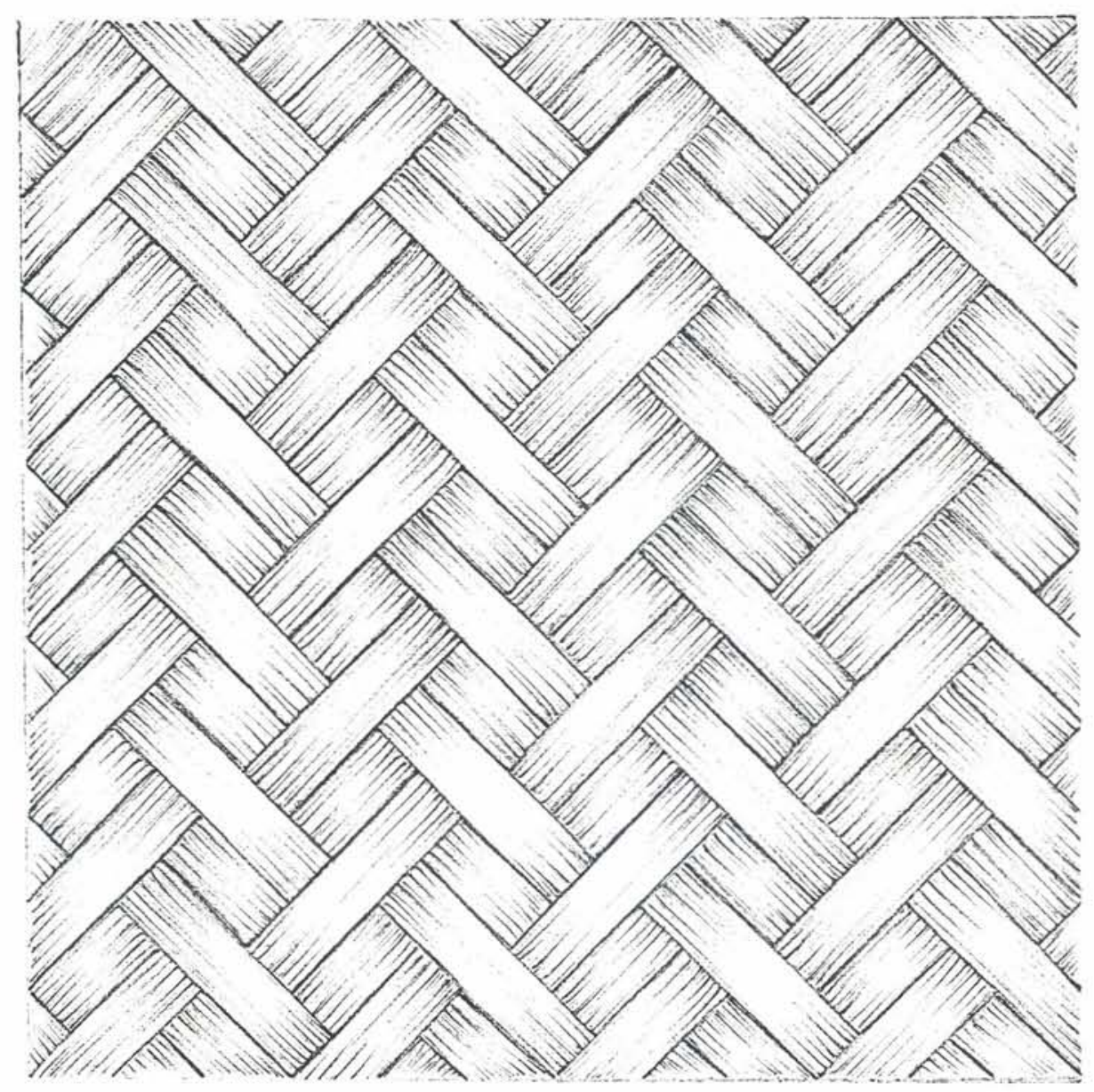

Figura 19e - Bojo de Kaipó: verso do bojo - R.G. n 9116. 
Se observamos todas as bases já mostradas, notaremos que elas se referem a Kaipó de formato quadrangular, mas os Krahó fabricam também Kaipó retangulares. A figura 20 ilustra um tipo de base de um Kaipó retangular. Notamos que o cesteiro a obteve iniando o trabalho do mesmo modo como faria para tecer a base da figura 19, repetindo essa operação inicial em uma direção até conseguir o comprimento desejado da base.

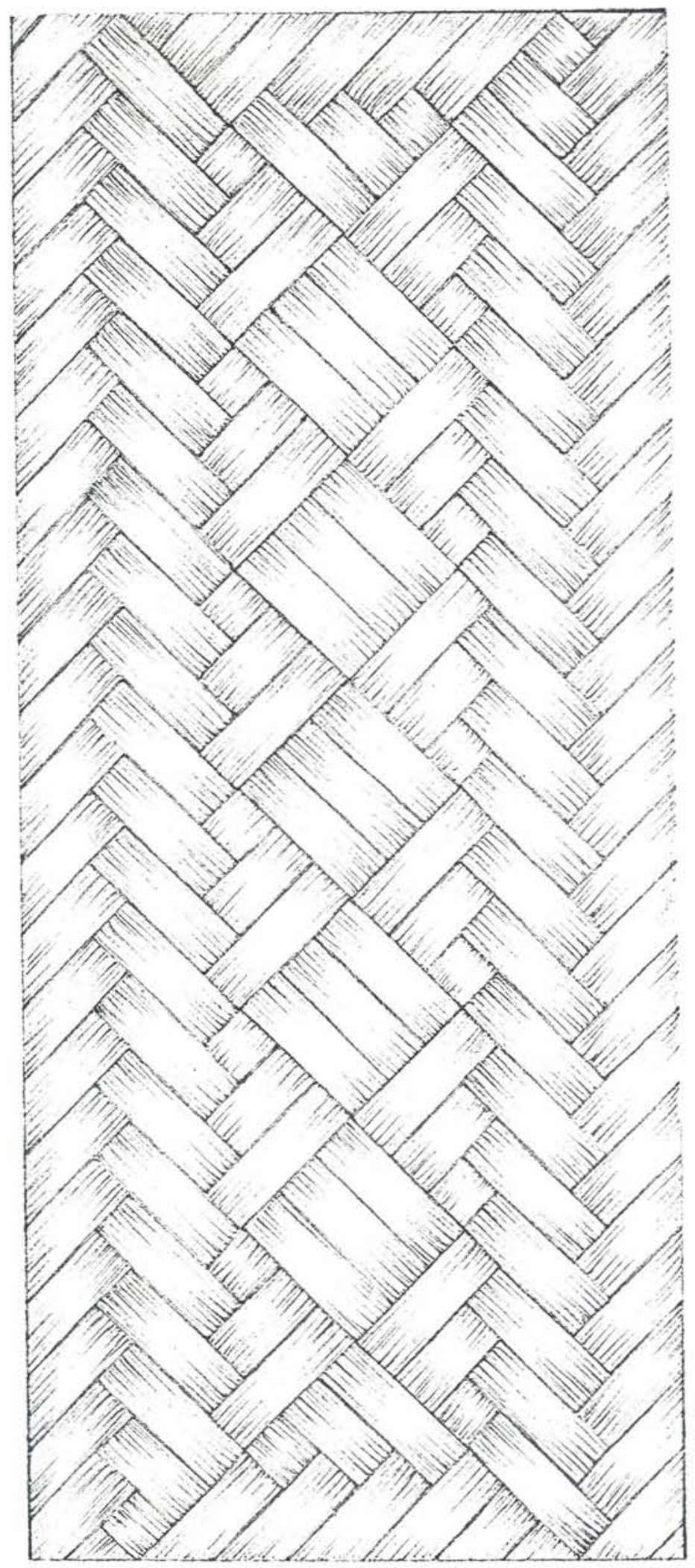

Figura 20 - Base de Kaipó -R.G. 10.366. 
$\mathrm{Na}$ figura $20 \mathrm{a}$ assinalamos que o enfeite, iroc, central, tem a direção vertical.

Como todos os iroc também são classificados pelos Krahó, segundo a direção do trançado diagonal, esse é um iroc kotxua.

Para a realização desse bojo foi necessário ao cesteiro passar do trançado horizontal próximo à base e decorrente dela para 0 iroc e dele novamente para o trançado horizontal próximo e obrigatório para à obtenção do remate do cesto.

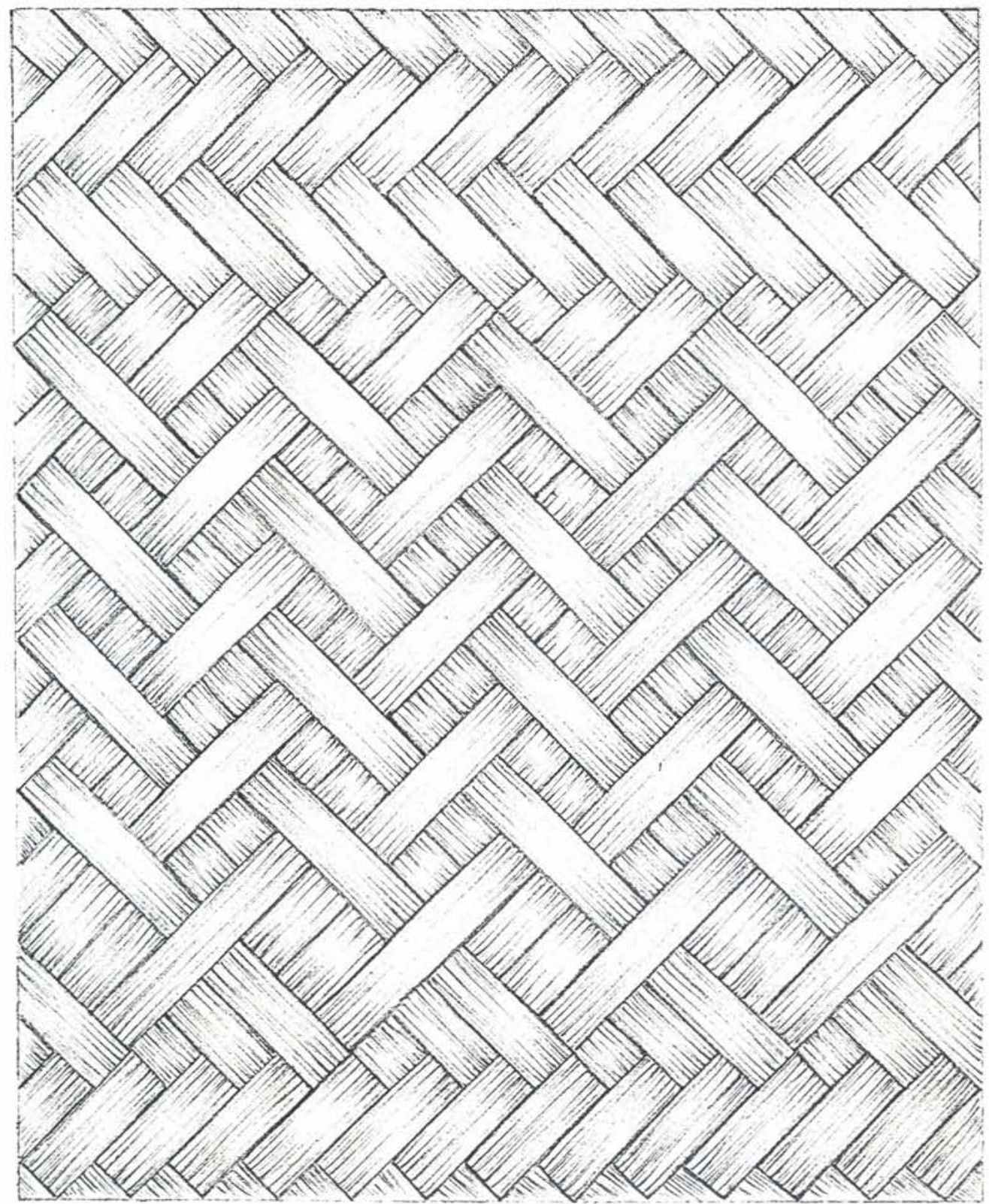

Figura 20a - Bojo de Kaipó - R.G. n 11.333. 
Na figura 20b o enfeite - iroc - é horizontal; é Kokaikor. Usando dois padrões de trançado ligeiramente diferentes para a nossa percepção visual, o cesteiro teceu no terço inferior do bojo o que chamaríamos de faixa. Essa localização dá equilíbrio à forma como um todo, pois a tampa do Kaipó ocupa exatamente o terço superior do bojo.

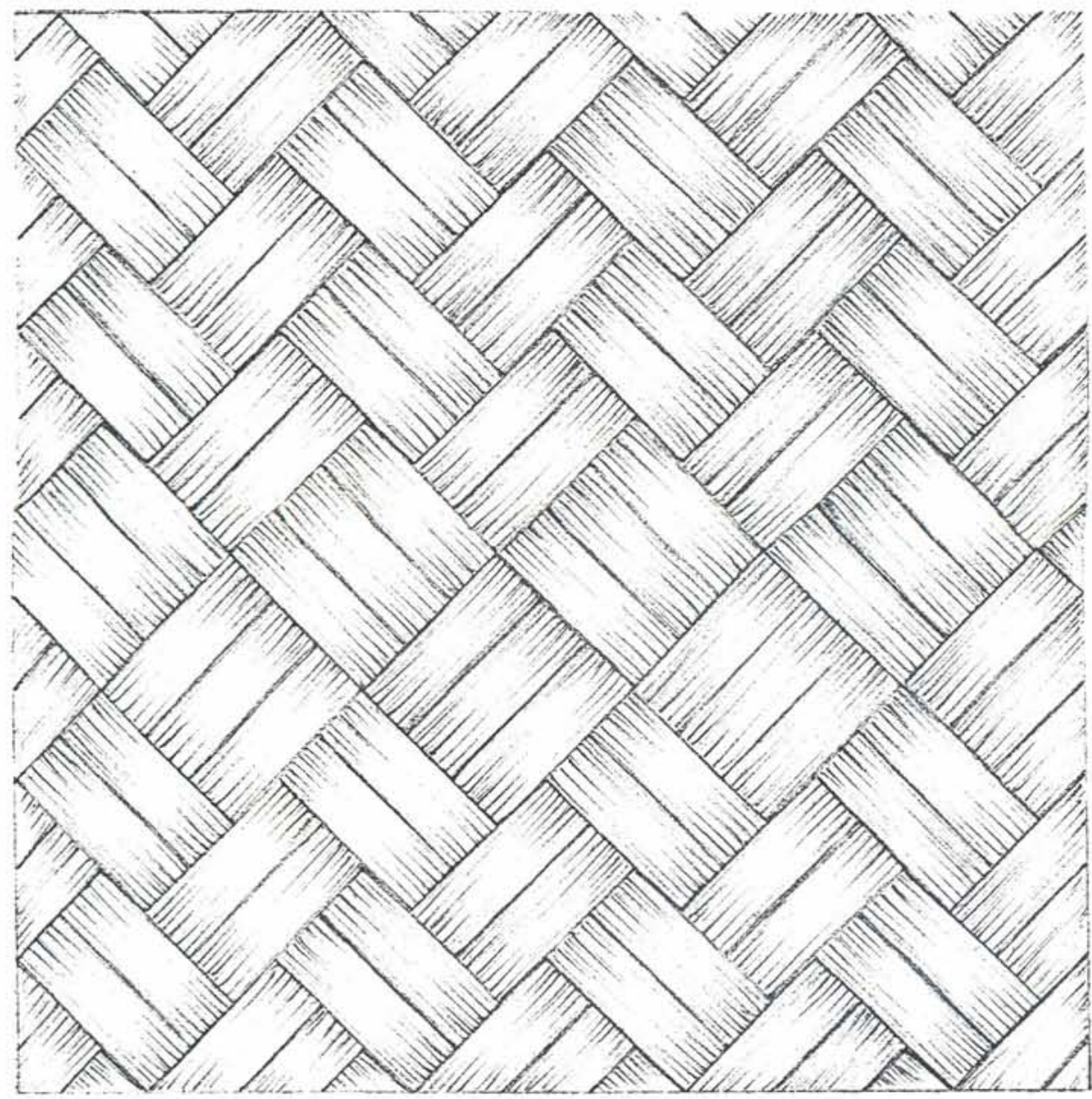

Figura 20b - Bojo de Kaipó - R.G. nº 34. 
A figura 21 representa outro tipo de base de Kaipó retangular.Trata-se, tecnicamente, também de uma variação da figura 19: o cesteiro repete a operação inicial em duas direções até obter a largura e o comprimento desejado da base.

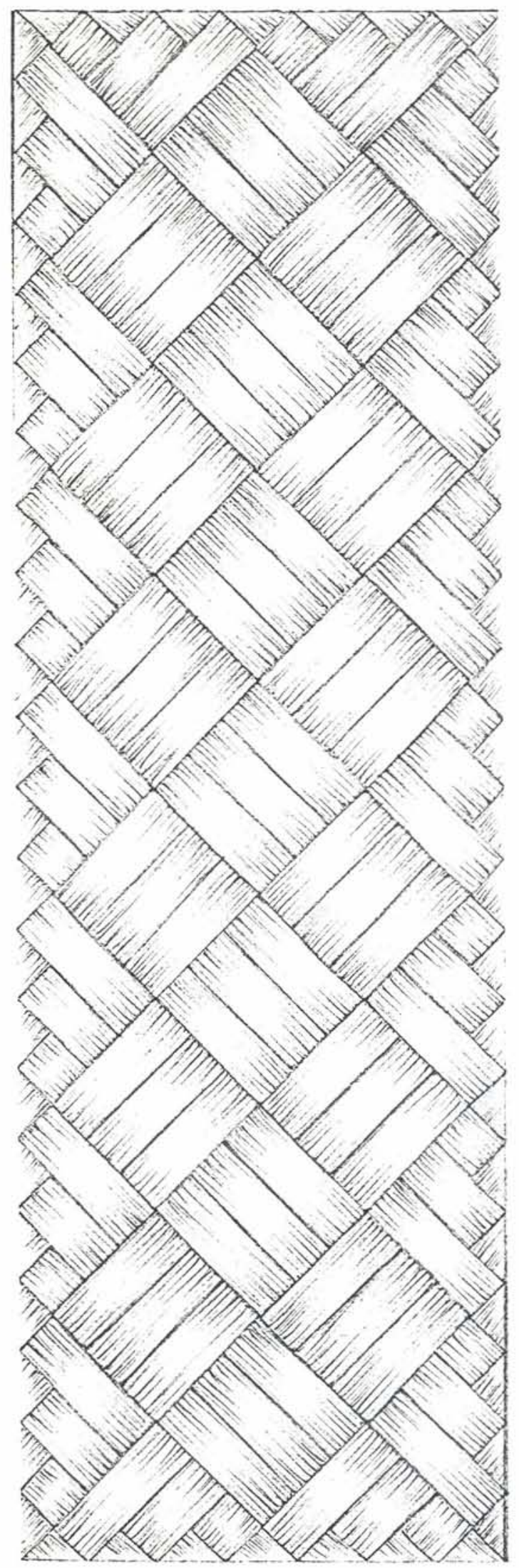

Figura 21 - Base do Kaipó - R.G. n 9.117. 
Em nossa amostra, todos os Kaipó confeccionados com a base anterior - da amostra - apresentam o bojo ilustrado na figura 21a, que é semelhante na composição e no enfeite ao bojo da figura 20a. São sutis diferenças permitidas pela acuidade visual dos Krahó.

Todos os Kaipó retangulares têm o bojo com enfeite, iroc; mesmo nos exemplares de reduzidas dimensões (8 centímetros de altura) os encontramos, demonstrando o domínio da técnica e indicando a importância desse procedimento para o cesteiro.

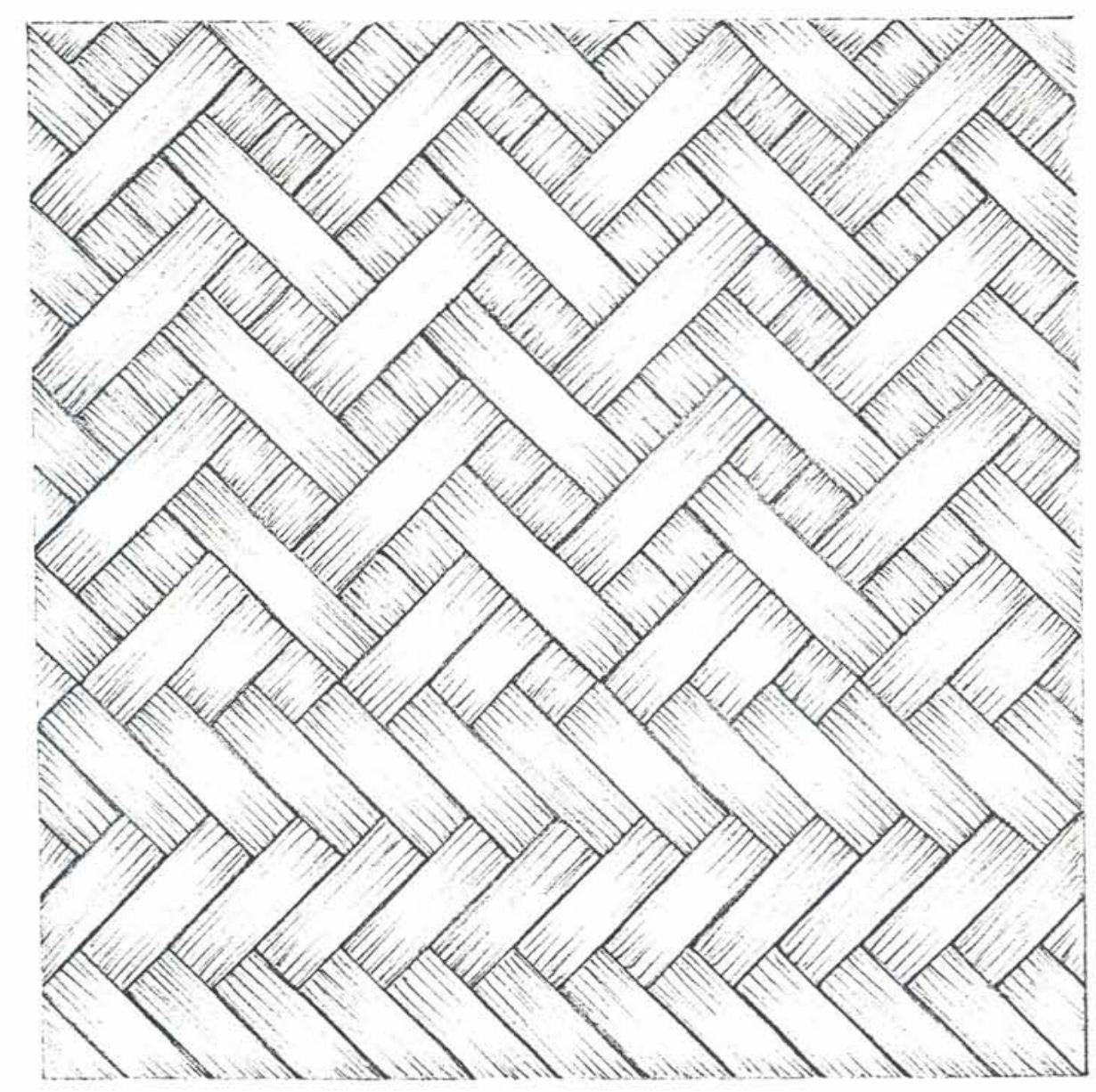

Figura 21a - Bojo de Kaipó - R.G. n 9.117. 


\section{IV - CONSIDERAÇÕES FINAIS}

Em primeiro lugar, esse estudo mostrou como um artefato - o cesto do tipo Kaipó - tomado como uma manifestação concreta de uma sociedade - os Krahó - nos permitiu estudar fenômenos sociais.

Partimos da seguinte proposição: o cesto Kaipó - como qualquer outro artefato - é uma totalidade decorrente da interação entre as necessidades do artesão, as qualidades da matéria-prima escolhida e as particularidades da tecnologia empregada, por consegüinte contém informações sobre a sociedade que o produziu.

O desenho de observação e a reconstrução da tecnologia empregada na fabricação do Kaipó mostraram-se meios valiosos para a aquisição de novos dados etnográficos sobre a sociedade Krahó, porque ao permitir a distinção entre as exigências próprias dos meios empregados e as preferências ou opções do artesão, direcionou essa pesquisa, que buscou explanar aquilo que para os krahó era importante.

Uma vez que a tecnologia é o processo pelo qual as idéias e a matéria-prima são elaboradas de modo a estruturar a forma desejada, tomamos os dados etnográficos obtidos através da investigação da tecnologia usada para a fabricação do Kaipó como fio condutor para a apresentação dos saldos desse estudo. 
Se nosso encaminhamento foi corrreto temos como saldo conquistas e o levantamento de questões a serem solucionadas.

Um primeiro dado etnográfico decorrente da análise do cesto Kaipó, mas que o extrapola, estendendo-se a outros artefatos, é a opção krahó pela técnica do trançado em diagonal.

No trançado em diagonal as fibras são necessariamente cruzadas aos pares. Pode-se cruzá-las em uma seqüência crescente ou decrescente, obtendo-se respectivamente um par vertical ou um par horizontal; visualmente temos $\mathbf{V} e<$

Ao par vertical os Krahó denominam Kotxua e ao horizontal Kokaikor.

Ambos estão classificados segundo o principal sistema de metades ordenador da sociedade Krahó: as metades Wakmeye e Katamye, que agrupam pessoas, animais, vegetais, astros, pontos cardeais, substâncias como a água, reações químicas e físicas como o fogo, as cores, e etc. O par Kotxua é Wakmeye e o par Kokaikor é Katamye.

Para a fabricação do Kaipó - e, de modo geral, da cestaria - são necessários ambos os pares: Kotxua e Kokaikor. Cada cesto é, portanto, a união de Wakmeye e Katamye. Na cestaria temos os complementares juntos, o todo.

Podemos compreender porque para os Krahó a cestaria não tem cor, é Hakati. Nesse sentido, os Krahó traçam um paralelo entre a cestaria e a pele humana Khö, pois esta, como a cestaria, 
também não tem cor e é exatamente com os sinais $\mathrm{V}$ ou < que a pele é marcada para identificar o lugar da pessoa no referido sistema de metades. É a noção de pessoa entre os Krahó que pode ser ainda mais estudada.

$\mathrm{O}$ trançado em diagonal relaciona-se à matéria-prima empregada na cestaria, o buriti.

Vimos acima que o traçado em diagonal permite à cestaria sintetizar as duas partes que compõem o mundo Krahó: Wakmeye e Katamye.

O buriti, parece-nos, que devido às suas características físicas e seu lugar na cosmologia Krahó, é um vegetal que também sintetiza essas mesmas metades.

De modo coerente, à cestaria, que não deixa de ser outra coisa senão trançado em diagonal, os Krahó denominam Krou-ro, isto é, buriti trançado.

As talas de buriti ao serem cruzadas aos pares fazem com que a luz incida de modo diferente na superfície de cada elemento de um par, criando uma textura visual com contraste. Esse contraste permite aos Krahó verem na monocromia das talas os padrões de trançado em diagonal.

Os dois tipos básicos de padrões são obtidos cruzandose as talas de buriti de modo regular, isto é, sempre com um mesmo intervalo entre as talas. Esses padrões são chamados Kotxua e Kokaikor, como vimos, segundo a direção do trançado. 
Mas há outros padrões que são obtidos cruzando-se as talas de buriti de modo irregular. A esses padrões os Krahó denominam "enfeite", iroc, e eles são específicos para cada artefato.

Assim, todos os inícios dos Kaipó - as bases - e todos os padrões irregulares dos bojos são enfeites, iroc, de Kaipó.

O fato desses padrões serem específicos dos Kaipó e de não os ter encontrado em campo, durante minha estada entre os Krahó, faz com que, a seguir, apenas apresente algumas questões decorrentes da análise desses padrões.

São padrões também classificados em Kotxua e Kokaikor, segundo a direção do trançado; porém, além disso, eles possuem um nome que os distingue entre si. Certamente, esse nome os coloca em relação a outras esferas do pensamento Krahó. A que se referem esses "enfeites" específicos dos Kaipó?

A irregularidade empregada no cruzamento das talas faz com que nesses padrões a frente e o verso do trançado sejam diferentes.

Do ponto de vista técnico é viável empregar-se tanto a frente como o verso do trançado, mas os Krahó fazem uma seleção e utilizam indistintamente apenas alguns padrões.

No caso da base dos Kaipó, o uso indistinto da frente e do verso dos padrões tornariam possível confeccioná-lo de 23 maneiras diferentes. Os Krahó, no entanto, por serem seletivos, tecem 
o Kaipó de 15 maneiras. Uma vez que não há necessidade de ordem técnica, qual o motivo para essas opções culturais dos Krahó ?

Nos Kaipó, como vimos, há padrões irregulares, isto é, enfeites - iroc - em todas as bases, em alguns bojos dos cestos com base quadrangular e em especial nos bojos de todos os cestos retangulares, mesmo nos exemplares de reduzidas dimensões. Por que um homem tecia Kaipós com padrões complicados, ou seja, tecia Kaipós enfeitados, ao invés de tecê-los de modo mais simples, o que é tecnicamente mais facil?

Certamente seu ato respondia a outras necessidades que não as utilitárias. Do ponto de vista utilitário, o mais fácil padrão da base - o da figura 1 - e o simples trançado em diagonal Kotxua e Kokaikor, executado com as talas de buriti, já permitiriam tecer um "armarinho", como tão bem o definiu o Sr. Xavier, na aldeia de Cachoeira, em 1990.

A rigidez das talas de buriti conferem ao Kaipó pouca maleabilidade. A confecção da tampa com as mesmas dimensões da base faz com que essa se encaixe no bojo, protegendo a área interna do cesto. A tampa e o bojo articulam-se através do cordel lateral, cuja utilidade não é só manter essas partes juntas, mas fechar o cesto com o nó próprio e pendurá-lo no seu lugar, que é o esteio da casa, sobre a cama de sua proprietária, providencias que garantiam a individualidade dos ítens guardados no cesto.

Esse "armarinho" Kaipó guardava alimentos especiais, pequenos objetos, tais como pinça, tesoura e etc. e o coco-de babaçu matéria-prima para a confecçõo do carimbo usado na pintura corporal, extração do óleo usado nos cabelos e extração do sumo para o preparo 
da tinta de urucu. De modo geral, os Kaipó de tamanho grande não guardavam miudezas e reciprocamente os pequenos não guardavam alimentos; essa regra geral era permeada por outra, que especificava o Kaipó próprio para o ítem ou ítens a serem guardados. Sugerimos que tal especificidade se relacionava com o significado dos padrões, enfeites dos Kaipó.

O Kaipó era um cesto de posse feminina e, de modo coerente, as miudezas e o coco-de-babaçu guardados nesse cesto permitiam à mulher transformar os corpos humanos.

A depilação, o corte e cuidado dos cabelos e o ato de colorir a pele são atividades relacionadas à construção da pessoa Krahó e realizadas pelas mulheres; elas elaboram o corpo das crianças, das mulheres e dos homens seus parentes.

Assim, o Kaipó era um "armarinho" pessoal, que guardava ítens de propriedade individual, mas de consumo coletivo, mediado por sua proprietária.

O Kaipó era um cesto confeccionado pelos homens. Entre eles, era o marido ou um seu parente afim que a seu pedido confeccionava o Kaipó para a esposa. O Kaipó enquanto artefato, objeto concreto, explicitava uma relação de afinidade entre marido e esposa - quer por casamento ou por nominação - e como decorrência, a aliança social existente entre os grupos envolvidos nessa relação.

Em termos mais amplos o Kaipó perpassa, diz respeito e integra diferentes aspectos da sociedade Krahó, o que este estudo,com todas as suas lacunas, circunstâncias e intrínsecas, deixa claro. 


\section{VI - REFERÊNCIAS BIBLIOGRÁFICAS}

ALVES, M.R.P. \& DANATÊE, P.E.M. - Palmeiras: Características Botânicas e Evolução. São Paulo, Fundação Cargill, 1987.

ARNHEIM, R. - Arte e Percepção Visual: Uma Psicologia da Visão Criadora. Trad.: Ivonne Terezinha de Faria. São Paulo, Pioneira / EDUSP, 1980.

BALDUS, H. - Os Carimbos dos Índios dos Brasil. Revista do Museu Paulista, N.S. São Paulo, Vol. 13, 1961/62.

BARTHES, R. - A Câmara Clara; Nota Sobre a Fotografia. Trad.: Júlio Castanõn Guimarães. Rio de Janeiro, Nova Fronteira, 1984.

BOAS, F. - El Arte Primitivo. Trad.: Adrián Recinos. México. Fondo de Cultura Economica, 1947.

BOHANNAN, P. - Social Anthropology. New York, Holt, 1963.

BOSI, A. - Fenomelogia do Olhar. In: O Olhar. Novaes, A. (org.). São Paulo, Companhia das Letras, 1989.

CORRÊA, M.P. - Dicionário das Plantas Úteis do Brasil e das Exóticas Cultivadas. Rio de Janeiro, Imprensa Nacional, Volume I, 1926.

CUNHA, M.C. - Os Mortos e os Outros. São Paulo, Hucitec, 1978.

DERVILE, A. - Ecologia Objetiva. São Paulo, Nobel, 1981. 
FOCILLON, H. - A Vida das Formas. Lisboa, Edições 70, 1988.

GEERTZ, C. - Art As A Cultural System. In: Local Knowledge. New York, Basic Book Inc. Publishers, 1983.

LADEIRA, M.E. - A Troca de Nomes e a Troca de Cônjuges: Uma Contribuição ao Estudo do Parentesco Timbira. Dissertação de Mestrado Inédita. Universidade de São Paulo, 1982.

LÉVI-STRAUSS, C. - O Uso das Plantas Silvestres da América do Sul Tropical. In: Suma Etnológica Brasileira - Vol. I. Cood. Ribeiro, B.G. Petrópolis, Vozes/Finep, 1987.

MELATTI, J.C. - Ritos de uma Tribo Timbira. São Paulo, Editora Ática, 1978.

MUNN, N. - The Spatiotemporal Transformations of Gawa Canoes. Journal de la Societé des Oceanistes. Paris, 1979.

NEIMAN, Z. - Era Verde ? Ecossistemas Brasileiros Ameaçados. São Paulo, Editora Atual, 1989.

NIMUENDAJU', C. - The Eastern Timbira. University of California Publications in American Archeology and Ethnology. Vol. 41, 1946.

OLIVEIRA, L.R.C. - Artesanato Krahó: Divisão de Trabalho e Trançado. Relatório Inédito. Centro Nacional de Referência Cultural. 1978. 
RIBEIRO, G.B. - Glossário dos Trançados Indígenas e A Arte de Trançar: Dois Macroestilos, Dois Modos de Vida. In: Suma Etnográfica Brasileira - Vol. II. Coord. Ribeiro, B.G. 2a ed. Petrópolis, Vozes/Finep, 1987.

SAINT-HILAIRE, A. - Viagem Pelas Províncias do Rio de Janeiro e Minas Gerais. Trad.: Vivaldi Moreira. Belo Horizonte / São Paulo, Itaiaia / EDUSP, 1975.

SCOTT, R.G. - Fundamentos del Diseño. Buenos Aires, Victor Leru, 1979.

SEEGER, A; DA MATA, R.; VIVEIROS DE CASTRO, E. - A Construção da Pessoa nas Sociedades Indígenas Brasileiras. Boletim do Museu Nacional, $\mathbf{n}^{\mathbf{0}}$ 32, N.S. Rio de Janeiro, 1979.

SPIX, J.B.V. \& MARTIUS, C.F.P.V. - Viagem Pelo Brasil: 18171820. Trad:: Lucia Furquim Lahmeyer. São Paulo, Editora Melhoramentos, 1938.

WHITEHEAD, P.J.P. - A Disciplina do Desenho: Quadros Etnográficos Holandeses do Brasil Setecentista. Trad:: Thekla Hartmann. Revista do Museu Paulista, N.S., Vol. 33. São Paulo, 1988.

WUSTMANN, E. - Crao. Radebeul, 1958. 


\section{VI - RESUMO}

Esse estudo objetiva mostrar a inserção sistemática do cesto do tipo Kaipó na sociedade Krahó.

Paralelamente sugere um meio de abordagem dos artefatos através do desenho de observação e da reconstrução técnica. Sugere, ainda, o uso do desenho de observação como meio de comunicação dos processos tecnológicos dos artefatos.

A análise dos aspectos visuais e estruturais da coleção de cestos Kaipó do acervo do Museu Paulista forneceu dados etnográficos. São 51 exemplares coletados por Harald Schultz e Vilma Chiara nas aldeias Krahó entre as décadas de 40 a 60.

$\mathrm{Na}$ atualidade dos Krahó não confeccionam o cesto Kaipó.

Assim, alguns dados etnográficos foram relacionados a diversos aspectos sociais e culturais dessa etnia, através da pesquisa de campo e da bibliografia pertinente. Outros dados etnográficos remetem a questões, especialmente os trançados específicos desse tipo de cesto - os enfeites - e a seleção de trançados que adotavam frente a um leque de possibilidades suas conhecidas.

O cesto Kaipó expressava com seu trançado em diagonal de buriti um mesmo princípio dual ordenador do mundo Krahó. 
O cesto Kaipó explicitava aliança social entre parentes afins adquiridos via a relação marido-esposa. O cesto kaipó guardava os bens particulares de uma esposa - iguarias, miudezas e coco-debabaçu - os quais eram consumidos por outras pessoas, mas tendo a sua proprietária como mediadora.

De modo claro, as miudezas e o coco-de-babaçu são matéria-prima para a elaboração do corpo humano; através do corte dos cabelos, da depilação, dos adornos e do ato de colorir a pele a mulher constrói aspectos da pessoa Krahó, sejam outras mulheres, crianças e principalmente homens.

Essa característica do cesto permanece em uso: recipientes - latas circulares de folhas de flamdres - de tamanhos aproximadamente iguais aos Kaipó são usados com a mesma finalidade e com o mesmo gestual dos antigos Kaipó. 